NBER WORKING PAPER SERIES

\title{
CENTRAL BANK CREDIBILITY: AN HISTORICAL AND QUANTITATIVE EXPLORATION
}

\author{
Michael D. Bordo \\ Pierre L. Siklos \\ Working Paper 20824 \\ http://www.nber.org/papers/w20824 \\ NATIONAL BUREAU OF ECONOMIC RESEARCH \\ 1050 Massachusetts Avenue \\ Cambridge, MA 02138 \\ January 2015
}

Presented at the 2014 Norges Bank Conference "Of the Uses of Central Banks: Lessons from History", Oslo, Norway. The second author thanks CIGI-INET for financial support. Nicolo Battestini, Samantha St. Amand, and Cesar Tamayo provided excellent research assistance. Earlier versions of this paper were presented as a keynote presentation at the 7th Conference of the South-Eastern European Monetary History Network, Bank of Albania, the Norges Bank 2016 pre-conference at the Graduate Institute in Geneva, the 7th World Congress of the Cliometrics Society, the 2014 ASSA Conference (Cliometrics Society) in Philadelphia, and the 31st SUERF Colloquium and Baffi Finlawmetrics Conference in Milan (June 2014). Comments on earlier drafts by Oyvind, Eitrheim, Marc Flandreau, Peter Ireland, Lars Jonung, Josh Hausman, Athanasios Orphanides, and Eugene White, are gratefully acknowledged. We are also grateful to our discussant, Lars Svensson, for insightful comments as well as participants at the Norges Bank Conference and other conferences. The views expressed herein are those of the authors and do not necessarily reflect the views of the National Bureau of Economic Research.

At least one co-author has disclosed a financial relationship of potential relevance for this research. Further information is available online at http://www.nber.org/papers/w20824.ack

NBER working papers are circulated for discussion and comment purposes. They have not been peerreviewed or been subject to the review by the NBER Board of Directors that accompanies official NBER publications.

(C) 2015 by Michael D. Bordo and Pierre L. Siklos. All rights reserved. Short sections of text, not to exceed two paragraphs, may be quoted without explicit permission provided that full credit, including (c) notice, is given to the source. 
Central Bank Credibility: An Historical and Quantitative Exploration

Michael D. Bordo and Pierre L. Siklos

NBER Working Paper No. 20824

January 2015

JEL No. C32,C36,E31,E58,N10

\begin{abstract}
$\underline{\text { ABSTRACT }}$
In this paper we provide empirical measures of central bank credibility and augment these with historical narratives from eleven countries. To the extent we are able to apply reliable institutional information we can also indirectly assess their role in influencing the credibility of the monetary authority. We focus on measures of inflation expectations, the mean reversion properties of inflation, and indicators of exchange rate risk. In addition we place some emphasis on whether credibility is particularly vulnerable during financial crises, whether its evolution is a function of the type of crisis or its kind (i.e., currency, banking, sovereign debt crises). We find credibility changes over time are frequent and can be significant. Nevertheless, no robust empirical connection between the size of an economic shock (e.g., the Great Depression) and loss of credibility is found. Second, the frequency with which the world economy experiences economic and financial crises, institutional factors (i.e., the quality of governance) plays an important role in preventing a loss of credibility. Third, credibility shocks are dependent on the type of monetary policy regime in place. Finally, credibility is most affected by whether the shock can be associated with policy errors.
\end{abstract}

Michael D. Bordo

Department of Economics

Rutgers University

New Jersey Hall

75 Hamilton Street

New Brunswick, NJ 08901

and NBER

bordo@econ.rutgers.edu

Pierre L. Siklos

Wilfrid Laurier University

75 University Ave

Waterloo, ON, CANADA, N2L 3C5

psiklos@wlu.ca 


\section{Introduction}

Central Bank credibility is defined as a commitment to follow well articulated and transparent rules and policy goals. More precisely, credibility refers to the "...extent to which the public believes that a shift in policy has taken place when, indeed, such a shift has actually occurred“(Cukierman 1986, p.6). Blinder (1999, p. 64-65) offers a more prosaic definition, namely “... that your pronouncements are believed - even though you are bound by no rule and may have an incentive to renege." He goes on to add: “...it is ... built up by a history of matching deeds to words." More generally, Brunner (1983) makes the connection between credibility and the performance of the institutions mandated to carry out policies: "Credibility depends...on the history of policy making and the behavior of the policy institution."

We recognize that central banks may have adopted several goals over time (e.g., the price of gold, exchange rate pegs, monetary targets, inflation targets). Partly for practical reasons, but also because alternatives to inflation objectives are typically subservient to the goal of controlling the rate of change in the price level, we interpret credibility in terms of inflation performance. Our approach has the virtue of being quantifiable. However, we recognize that such a broad definition could also be viewed at times as being too restrictive. Put differently, model-based estimates of credibility can be sensitive to the parameterizations employed. Therefore, while numerical estimates of credibility are useful these can only tell an incomplete story. Hence, we supplement the quantitative approach with narrative evidence.

Credibility then is best thought of as a flow like variable that changes as observed inflation is seen to deviate from a time-varying inflation objective, which need not be explicit or publicly announced. Credibility is also partially determined by the relative importance the central bank attaches to real and nominal economic objectives. Regular economic shocks and the manner in which the central bank manipulates monetary policy instruments dictate how credibility evolves over time.

Credibility evolves possibly in a non-linear manner, is earned slowly and painstakingly yet susceptible to evaporate on a moment's notice. In the words of Benjamin Franklin "It 
takes many good deeds to build a good reputation, and only one bad one to lose it." 2 Identifying and measuring credibility is challenging. Nevertheless, as Cukierman (1986, p.5) again points out, “...the ability of monetary policymakers to achieve their future objectives depends on the inflationary expectations of the public. These inflationary expectations depend, in turn, on the public's evaluation of the credibility of the monetary policy makers..." Paul Volcker, former Chair of the U.S. Federal Reserve's Open Market Committee (FOMC), once underscored the point that "[T]o break the inflation cycle we must have credible and disciplined monetary policy" (Bernanke 2013, p. 35). Indeed, Volcker went on to remark that “...inflation undermines trust in government." (Silber 2012, p. 266). Therefore, autonomy, transparency, accountability, and the monetary policy strategy in place each can influence both the credibility and reputation of the monetary authority.

Not everyone shares the view that credibility is a sought after objective of central banks. Romer (2013, p. 109), for example, claims: "There is remarkably little evidence that credibility in monetary policy making buys one much when it comes to lowering the costs of disinflation." Ball (1994), and Ball and Sheridan (2005), are similarly skeptical. Notice, however, that Romer's criticism relates to views about the costs of lowering inflation and this is also highly dependent not only on how expectations are formed but on the constraints faced by the monetary authorities. Ball and Sheridan's (2005) analysis is selective and appears to be offset by contrary evidence based on the success of regimes such as inflation targeting. Mishkin (2005), for example, reviews the arguments against a role for credibility and finds them wanting. ${ }^{3}$

In this paper we back up our interpretation of central bank behavior with measures of credibility. To the extent that we are able to apply reliable institutional information we can also indirectly assess their role in influencing the credibility of the monetary authority. We

\footnotetext{
${ }^{2}$ Experimental evidence (e.g., List 2006) suggests that reputation and the monitoring of quality are complements. Our definition of credibility is, in effect, a quality assessment exercise, and reputation, that is, the ability of a central bank to deliver the promised monetary policy outcome over time, seems consistent with the stock-flow distinction made above.

${ }^{3}$ Part of the difficulty is that the definition of credibility is not unique. The theoretical literature also views the concept as akin to a central bank being bound by a rule and this raises the possibility of time inconsistency. The definition adopted here is, admittedly, a simpler one. More recently, Geraats (2014) has raised further doubts about the methodology used by Ball and Sheridan (2005).
} 
focus on measures of inflation expectations, the mean reversion properties of inflation, and movements in interest rates, money growth, and exchange rate movements. In addition we will place some emphasis on whether credibility is particularly vulnerable during financial crises. As Carney (2013), former Governor of the Bank of Canada, points out: "Financial imbalances ultimately breed crises, and crises threaten price stability." Crises, especially of the financial variety, play a role in influencing the ability of a central bank to maintain price stability. A monetary authority with a reputation for delivering on its promises will likely have an easier time of it, as well as the flexibility to temporarily deviate from a rule, than one with poorly established credibility. Is credibility linked to improvements in macroeconomic conditions? Is credibility in monetary policy also affected by other factors such as the growth of private credit?

Clearly, credibility will also be influenced not only by how observed inflation behaves over time but, by implication, according to how expectations of inflation are formed. As argued above, expectations formation lies at the core of any definition of credibility. of course, as Eggertsson and Woodford (2003) point out that: “...the power of the expectations channel of monetary policy is highly sensitive to the precise manner in which expectations are formed..." As a result, there is the possibility that our definition concerns how well central banks have achieved their target as opposed to how their actions are reflected in changing inflation expectations. ${ }^{4}$ It is for this reason that we are careful to argue that, as imperfect as our measure may be, we strive to assess credibility on the basis of how monetary policy actions and regimes over time are reflected in some proxy for inflation expectations. ${ }^{5} \mathrm{~A}$ study that relies on a shorter time span than the century or more of data used in this paper would be able to rely on more direct measures of inflationary expectations but at the expense of investigating the role of credibility over far fewer policy regimes.

Central banks can, at least for our purposes, be thought of as institutions responsible for price stability and economic stabilization which, for simplicity, we will refer to as monetary

\footnotetext{
${ }^{4}$ Indeed Lars Svensson, our discussant, drew attention to the useful distinction between inflation target achievement and credibility. For example, he argues that the Riksbank's performance in achieving it inflation target since the mid-1990s is not good (in contrast to the Canadian experience) but that the central bank's target has been credible based on market-based expectations. As stressed later our measure need not be equivalent to some publicly announced inflation target.

${ }^{5}$ In fact, we consider several proxies as discussed below.
} 
stability, as well as having possibly a role in ensuring financial stability. Traditionally, financial stability meant serving as a lender of last resort (LOLR) to the commercial banking system and protecting the payments mechanism. The concept has recently been extended to include the prevention of contagion from the non-bank financial sector and heading off asset price booms before they can burst.

A complication arises when one attempts to understand how these twin responsibilities are, institutionally, linked to each other. The separation can be formal, as in the case of the European Central Bank, or the Bank of England prior to the recent global financial crisis, or informal as when central banks choose to focus on one activity at the expense of the other. Reinhart and Rogoff (2013) posit that the U.S. Federal Reserve is a case in point.

However, theirs is a revisionist view of the financial stability task assigned to the Fed. Responsibility for financial stability did not apply to non-member banks. Moreover, there was no formal mechanism which would permit the Fed to intervene in what we now call shadow banking. In other words, there was insufficient institutional flexibility to permit intervention in the financial system that might prove necessary in response to financial innovations. Legislation tended to define the circumstances under which the central bank intervened and, when it did not do so, politicians reacted by placing additional limits on the Fed's room to maneuver in financial sector interventions. Finally, whereas the Fed's creation did away with seasonality in interest rate movements (e.g., see Mankiw and Miron 1991), certainly a contribution to financial stability, central banks more generally were not created to manage asset booms and busts.

Instead, the Fed was led to focus on monetary stability after World War II. Next, we have central banks where there is clear recognition that the twin responsibilities of the central bank for monetary and financial stability overlap. Arguably, most central banks were of this variety, at least until 2007 or so. Consequently, the mandate of the central bank, its autonomy with respect to the government, the governance of the institution, to name but three important determinants, also provide clues about how a central bank is able to manage its credibility over time.

Finally, the type of central bank will also dictate which instruments are at its disposal and how many are likely to be deployed at any given time. Presumably, central banks where monetary and financial stability are both integral to the conduct of policy rely on 
more instruments than a monetary authority where stabilization policies are effectively divorced from financial stability concerns. Ultimately, however, the scope of the LOLR function (see Table 1) is critical. A central bank that is statutorily prohibited from intervening under certain circumstances (e.g., the Fed and the ECB) is likely to have different consequences for financial stability than a monetary authority which is prepared to intervene on a broad scale. Therefore, the credibility and reputation of the central bank will be dictated by a more complex set of factors which, for brevity, we will refer to as institutionally driven.

In an historical study it is unclear how we should define the benchmark against which inflation deviates from some expected value. Accordingly, we consider a number of approaches. For example, we apply statistical break tests to determine breaks in the inflation rate. This permits us to evaluate one indicator of deviations of realized inflation from some expectation, namely deviations from a statistically estimated trend inflation rate.

Yet another strategy consists in comparing monetary policy performance against examples when, with the hindsight of history, policies are thought to have been delivered credibly and the reputation of the central bank was considered to be stellar. Historical examples from Germany or Switzerland, the US during the Great Moderation from approximately 1986 to 2007, or the period since certain central banks adopted and maintained numerical inflation targets beginning in the mid 1990s, readily come to mind. The implication then is that an evaluation of central bank credibility and reputation is enhanced by narratives of central bank actions through time.

Next, we ask how the hypothesized credibility indicator reacts to the past history of inflation, various proxies for economic growth performance, or the output gap, the stage and shape of particular business cycle events (i.e., recessions versus recoveries, their size and shape; see, for example, Bordo and Haubrich 2010) as well as other variables such as wars, financial crises and financial market conditions. We also aim to empirically establish whether credibility behaves asymmetrically over time.

An historical perspective also enables us to deal with another under-emphasized element of central bank performance, namely whether deflationary periods, or the threat of deflation, also influences central bank credibility. Burdekin and Siklos (2004a), based on a 
cross-section of countries covering a long span of time, have shown that macroeconomic shocks are strikingly different between inflationary and deflationary samples. We can also draw upon the rich examples of the consequences of deflation covered by several other authors (e.g., also see Burdekin and Siklos 2004). The upshot is that there is potentially an asymmetry that could further contribute to introducing non-linearity in the behavior of central bank reputation over time.

The rest of the paper is organized as follows. The next section provides a brief narrative exploration of the nature and evolution of credibility through time and across a select number of countries. ${ }^{6}$ We then provide some theoretical underpinnings for the proposed empirical exercise aimed at evaluating how central bank credibility and reputation have evolved over time. ${ }^{7}$ Next, we provide a brief description of the data and discuss some methodological considerations. Section 4 discusses our main findings. Section 5 concludes.

Briefly, we find credibility changes over time are frequent and can be sizeable. For example, there is robust evidence that the Gold Standard improves central bank credibility. Similarly, in the post World War II era, central bank independence reliably improved credibility. Finally, there is some evidence that financial crises damage central bank credibility. However, the gap between observed and the central bank's inflation goal must be fairly large for this to happen. Hence, credibility is significantly affected according to whether the shock can be associated with policy errors. Bernanke (2013, p. 23), for example, has acknowledged that such errors can play an important role in explaining the severity of the most recent 'global' financial crisis. Moreover, institutional factors (i.e., the quality of governance) can play an important role in mitigating reputational loss. Lastly, credibility shocks are dependent on the type of monetary policy regime in place.

\section{Credibility and Reputation Through the Ages}

The history of central bank credibility is tied up with the history of policy regimes. Consider, for example, the classical gold standard as a rule based on the commitment to maintain the official peg. Central banks (independent of the fiscal authorities) in many of the advanced countries of Europe adhered to this rule from 1880 to 1914. According to the

\footnotetext{
${ }^{6}$ An Annex presents detailed Narratives on the historical evolution of 11 advanced country central banks.

${ }^{7}$ Some technical details are mainly relegated to an Appendix.
} 
rule temporary suspension was allowed during a wartime emergency or a serious financial crisis. In such situations central banks issued paper money to help finance the government's fiscal deficit. Once the emergency ended the central bank was required to restore convertibility to gold at the prewar official parity. If it did this it would ensure its credibility and allow it to use its seigniorage to finance a future war (Bordo and Kydland 1995). Credible adherence to the gold standard rule allowed central banks to have some leeway to conduct stabilization policies within the gold points (Bordo and MacDonald 2012). It also insured that it could conduct lender of last resort actions without engendering capital flight (Eichengreen 1997). The history of the pre 1914 gold standard shows how important countries, especially Britain, France and Germany, had credible regimes (see the Annex for examples from other countries with successes; e.g., Sweden and the United States, and failures; e.g., Italy's inability to deliver credible regimes). Many other peripheral countries tried to gain it but were less successful (Bordo and Schwartz 1996). ${ }^{8}$

World War I ended the classical gold standard and, after the war, many countries tried to rebuild the prewar system. Restoring the prewar parity after massive wartime inflation and changes in the political economy (suffrage) delayed the restoration of the gold standard and the standard that was established - the fragile gold exchange standard - had less credibility. Britain returned to gold at the prewar parity in 1925 but at an overvalued parity which continually threatened its adherence. The U.S. never left gold but the newly established Federal Reserve went through a lengthy learning period to become a fully functioning member of the central banking club (Meltzer 2001). France went through a period of high inflation and its central bank lost much of its credibility in a scandal. Germany went through a hyperinflation fueled by the Reichsbank. By 1926 the gold exchange standard was up and running and its short-lived success depended upon the reputations of Benjamin Strong, Montagu Norman, Emile Moreau and Hjalmar Schacht.

\footnotetext{
${ }^{8}$ Not everyone supports the view that rules implicit in regimes of the gold standard variety can generate credibility. Ferguson and Schularik (2008) suggest that in peripheral (i.e., less developed) economies there was no credibility bonus in adhering to a policy rule of the gold standard variety. Nevertheless, this view downplays the fact that credibility and reputation are inter-connected. Hence, even if the peripheral countries intended to generate credibility, theirs is an attempt to operate under rules governed by weak central banking institutions.
} 
Despite their efforts the system collapsed during the Great Depression. In its aftermath central bankers were blamed for the Depression and central banks lost their independence and became virtual appendages of the fiscal authorities. Academics still debate not only if too much authority was invested in central banks but whether a series of policy mistakes by governments, and other public institutions, combined to create the perfect storm resulting in the greatest economic slump of the $20^{\text {th }}$ century (e.g., Ahamed 2009, Meltzer 2010).

While the rules versus discretion debate concerning the conduct of monetary policy has a long history, and is likely to dominate discussions of central bank credibility and reputation, the institutional approach evaluates performance through the prism of the mandate of the central bank. Indeed, evaluations of central bank performance according to how autonomous and accountable they are, continues to pre-occupy academics and policy makers. While there exists a fairly broad consensus that central bank independence and accountability are essential ingredients in maintaining credibility and reputation (e.g., see Waller 2011), it is equally clear that there are serious reservations about our ability to objectively make the link between central bank mandates and inflation performance or the success of a particular monetary policy regime (e.g., see Parkin 2012, Cargill 2013). Matters become still more complicated when attempts are made to link central bank mandates with inflation prior to the 1950s (e.g., Dehay and Levy 2000). ${ }^{9}$

Regardless of one's view about the importance of central bank autonomy in explaining monetary policy performance central banks have become far more talkative over time and place a premium on their ability to communicate with the public. In this regard we may trace the origins of this phase in the evolution of central banks to the late 1950s when, then Governor of the Bank of Canada, James Coyne, was the target of heavy criticism, in both the press as well as from government officials, for speaking out in public on matters beyond the usual remit of monetary policy. Not only did Coyne view speeches and other reports published by the Bank of Canada as devices to explain monetary policy to the public but as a tool to underpin the central bank's credibility and reputation (Siklos 2010, and Powell

\footnotetext{
${ }^{9}$ Interestingly, Japan (low inflation and, until the 1990s, not an autonomous central bank) poses a problem for institutional hypotheses of central bank performance in more recent times, and also appears to be atypical of the central bank independence - low inflation nexus in the interwar era.
} 
2009). This sentiment would be echoed a little later by Karl Blessing, President of the Bundesbank from 1958 to 1969, who argued: "A central bank which never fights, which at times of economic tension never raises its voice...that central bank will be viewed with mistrust." (Marsh 1992, pp. 256-57) Therefore, whereas central banks were hampered by their unwillingness or inability to express their views or influence expectations via public pronouncements, the spread of transparency especially since the late 1990s has changed rather dramatically (e.g., see Siklos 2002, Dincer and Eichengreen 2007). Central banks are no longer shy about discussing matters beyond purely monetary policy questions.

In the 1950s, the Federal Reserve gained its independence and began following gold standard orthodoxy dedicated to price stability. Few other central banks, with the exception of the Bundesbank, the Swiss National Bank (SNB) and the Bank of Canada (BoC), followed suit. In Canada, policy makers suspended their participation in the Bretton Woods system for much of the 1950s. This allowed the BoC to regain its monetary independence although Canada's economic fortunes were increasingly linked to economic developments faced by its largest trading partner, the U.S. A crisis dented the reputation of the BoC in the late 1950s but it would be restored following important institutional reforms and with the return to the Bretton Woods fold (Siklos 2010). The theme linking independence to credibility and the role of the policy regime in dictating central bank behavior is a recurring one throughout the $20^{\text {th }}$ century (Siklos 2002).

In the U.S. the return to monetary orthodoxy rested on the reputation of William McChesney Martin after the 1951 Fed-Treasury Accord restored the Fed's independence to conduct monetary policy. The regained central bank credibility was, however, short lived. In the 1960s central banks (with the exception of the Bundesbank and the SNB) began following Keynesian policies to maintain full employment at the expense of higher inflation. The subsequent Great Inflation destroyed any vestiges of credibility as well as the reputations of central bankers such as Arthur Burns (Bordo and Orphanides 2013). Paul Volcker's adoption of a monetarist style tight monetary policy in 1979 broke the back of inflationary expectations at the expense of a deep recession in the U.S. Previously, inflation had drifted upward in a seemingly permanent fashion (e.g., see Goodfriend and King 2013, and De Long 1997) and it appears that only a form of 'shock therapy' could restore lower long-run inflationary expectations (e.g., see Levin and Taylor 2013). 
Similar strategies were followed in Canada, the UK, Japan and other countries (see the Annex) so that by the mid-1980s the Great Moderation restored price stability in the advanced countries along with the reputations of central bankers. However, in all of these instances (with the possible exception of Switzerland), credibility did not exist in the immediate postwar. It had to be earned at an economic price over time. Indeed, the lower the credibility of policies, the more adverse the economic costs are. This relationship has been understood for some time (e.g., Fellner 1976, Haberler 1980). The commitment to rules focused on low inflation helped to restore central bank credibility (e.g., see Levin and Taylor 2013 and Goodfriend 1986). What helped these central banks to succeed was that new policies were built on the reputation of their institutions. In Germany, the Bundesbank (DBB) gained credibility and a sterling reputation in the postwar period. The DBB was founded in 1948 with the express mandate to pursue price stability. This mandate was a reaction to the disastrous experience of its predecessor, the Reichsbank, in generating a hyperinflation in the 1920s.

Canada, like the US example under Volcker, offers another example of the trade-off between credibility and the costs of reducing inflation, occasionally referred to as the sacrifice ratio. Following years of inflation rates that were persistently higher than those in the US, the Canadian government, in cooperation with the Bank of Canada, adopted inflation targeting. In spite of the joint declaration to aim for low and stable inflation the recession of the early 1990s was among the sharpest in Canadian history (e.g., see Cross and Bergevin 2012). It led some to suggest that Canada, as a result of the tight monetary policy that helped influence inflationary expectations delivered a "Great Canadian Slump" (Fortin 1996). The Bank of Canada replied that supply side factors played a much greater role than critics of monetary policy allowed (Freedman and Macklem 1998). The Canadian example also highlights a recurring theme, namely the difficulty of identifying the proximate source of economic downturns, particularly severe ones, and the extent to which central banks ought to have anticipated these and calibrated their policies to mitigate the costs of a transition in adopting a new policy regime. ${ }^{10}$

${ }^{10}$ The adoption of inflation targeting was spurred by the record of monetary policy in the 1970s and 1980s. See Crow (2002) for a first-hand account by the Bank of Canada Governor at the time. 
In Germany the DBB gained credibility and a sterling reputation in the postwar period. In the next 50 years the DBB had the best track record of any advanced country in maintaining low inflation (Beyer et. al. 2013). Indeed during the Great Inflation, core inflation in West Germany increased only a fraction of that of the US and UK. Unlike central banks in other advanced country, the DBB did not accommodate the oil price shocks of the 1970s. This record of credible adherence to low inflation gave the DBB a very strong reputation which the ECB, founded in 1999, tried to emulate. The Swiss National Bank also followed a policy like Germany's from its origin in 1907 and had one of the best inflation fighting track records of any central bank in the twentieth century (Bordo and James 2007) ( for other countries see the Annex).

The fact that central banks, mainly in Anglo-Saxon countries, appear to attach relatively more weight to the statutory relationship between central banks and governments suggests that certain cultural factors might also be in play (e.g., Eijffinger and De Haan 1996, La Porta, Lopez-de-Silanes, and Schleifer 2008). Moreover, if cultural factors also impact business cycles, at least in some parts of the world (e.g., see Altug and Canova 2013), then there exists another avenue through which the central bank's credibility and reputation can be altered.

The series of financial crises that have, since 2007, gripped the advanced economies especially led to massive discretionary intervention in financial markets by central banks around the world. Many of the actions mixed monetary with fiscal policy and appeared to violate central bank independence. The changes in the legislative and regulatory landscape that followed have expanded the role of central banks. Time will tell if their credibility to maintain low inflation will survive. However, unlike earlier episodes in the monetary history of the last century or so, it is the fear of deflation and depression that has fueled central banks' responses. It is, therefore, worth contemplating whether the ability of central banks to ease policies by historically unheard of amounts, without signs that inflation expectations are becoming unanchored, is a sign of the triumph of central bank credibility and the strength of their reputation (also see Borio and Filardo 2004).

Has the industrial world, in particular, adopted a 'culture of stability' that seemingly explains Germany's and Switzerland's success in avoiding the Great Inflation of the 1970s and 1980s? (e.g., see Beyer et. al. 2013). As Bernanke (2013, p. 63) notes: "People get used 
to what they see." And the industrial world has experienced low and stable inflation rates for approximately two decades. The implication of Bernanke's comment is that low and stable observed inflation rates give meaning to the concept of price stability which, as former Fed Chairman Alan Greenspan (1996, p. 1) remarks: “...obtains when economic agents no longer take account of the prospective changes in the general price level in their economic decision-making."

Alternatively, central bank credibility may have suffered recently, based on expectations about what central banks can and cannot do, because the public does not believe the current policy is compatible with the reliance on numerical objectives for evaluating the performance of monetary policy. It may be that inflation expectations are no longer a sufficient guide of policy credibility. By the same token, changes in the responsibilities central banks are faced with also raise questions about the reputation of these institutions and whether they have become overburdened with responsibilities that are bound to conflict with each other (e.g., see Siklos 2014).

\section{Quantifying Credibility}

\subsection{The Taylor Rule, Credibility, and Policy Regimes}

Since Taylor's (1993) celebrated article many discussions about policy rules revolve around an expression of the following kind:

$$
i_{t}=\bar{\rho}+\bar{\pi}+\alpha_{2} \tilde{\pi}_{t}+\alpha_{3} \tilde{y}_{t}+\varepsilon_{i, t}
$$

where $i_{t}$ is the central bank's policy rate, $\bar{\rho}$ is the natural real interest rate, $\tilde{\pi}_{t}$ is an indicator of the inflation gap, $\tilde{y}_{t}$ is the output gap. The inflation gap can either be the difference between realized and expected or forecasted inflation, or represented by some deviation from an explicit inflation objective. In Taylor's original formulation, $\bar{\rho}$ is set at $2 \%$, as is the inflation objective, while $\alpha_{2}, \alpha_{3}$ were each calibrated to equal $1 / 2$. Since that time many central banks have adopted a $2 \%$ inflation objective, generally for the medium-term (i.e., a 2 to 3 year horizon). Instead of an explicit numerical objective a model-based estimate of the central bank's implicit inflation objective can be used to generate $\tilde{\pi}$ since central banks, 
generally, are not expected to meet the stated objective on an annual basis let alone at quarterly or monthly frequencies.

The output gap, $\tilde{y}_{t}$, defined as deviations of observed real GDP $\left(y_{t}\right)$ from potential output $\left(y_{t}^{*}\right)$, is likely unobserved given lags in obtaining economy-wide output data (i.e., real GDP). Consequently, many empirical applications resort to $\tilde{y}_{t-1}$ instead of relying on the contemporaneous output gap. ${ }^{11}$ Note that (1.1) assumes that $\rho+\bar{\pi}$ is time-invariant. If inflation drifts over time, as was the case during the Great Inflation of the 1970s and 1980s (e.g., see Goodfriend and King 2013), then the intercept of the Taylor rule would also change over time with consequences for central bank credibility.

Arguably, a big challenge with equation (1.1) is estimating potential or trend output. Several techniques are available. While the Hodrick-Prescott filter is probably the most widely used method there is no agreement on which method is best (e.g., see Dupasquier, Guay, and St-Amant 1999, van Norden and Orphanides 2002, and Mishkin 2007).12

If the hallmark of good policy making involves setting today's policy instrument in a forward-looking manner then it is preferable to replace $\tilde{\pi}_{t}$ and $\tilde{y}_{t-1}$ with their expected values (e.g., $E_{t} \tilde{\pi}_{t+1}, E_{t} \tilde{y}_{t+1}$ ), whether these are model generated or rely on published forecasts. Woodford (2003) demonstrates that some history dependence is required to implement policy in a stable fashion. As a result, central banks generally do not always adjust their policy instrument according to equation (1.1). Instead, policy rate changes may be 'smoothed' over time. One way to introduce this feature into the reaction function is by adding a lagged dependent variable (i.e., $i_{t-1}$ ). ${ }^{13}$ Another limitation of Taylor's original formulation, and many of its variants, stems from the role of the policy rate at or near the zero lower bound (ZLB). For example, simulations by Chung et al. (2012) reveal that very

\footnotetext{
${ }^{11}$ Alternatively, one can replace the output gap with an unemployment rate gap. There is the additional difficulty, in this connection, stemming from the fact that central banks may not make policy decisions on a monthly or quarterly basis. The U.S. Federal Reserve, for example, renders decisions 8 times a year.

${ }^{12}$ Borio (2013) argues in favor of an output gap concept that incorporates financial asset prices. With few exceptions, however, such data are not available for a long span of time nor is it immediately clear whether financial assets were important prior to, say, the 1980s in influencing the output gap. Likely, a more significant influence on changes in potential output are recessions. Also, see Haltmaier (2012).

${ }^{13}$ Rudebusch (2006) casts doubts on the interest rate smoothing hypothesis because interest rate changes are unpredictable, among other reasons. In contrast, Goodhart (1999) posits several plausible reasons in support of the interest rate smoothing phenomenon, including the unwillingness of central banks to be seen as frequently enacting policy reversals. Also, see Sack and Wieland (2000), and Rudebusch (2002).
} 
low inflation objectives (viz., below 2\%) frequently lead to the ZLB being reached. Consequently, either the central bank reacts more aggressively to the output gap when the policy rate is low or it reduces the policy rate to zero more quickly than any standard Taylor rule might recommend.

It is not an exaggeration to state that central banks through the decades have followed some type of 'rule', explicit or not, since most central banks have always been created, among other tasks to be carried out (e.g., an exchange rate, economic activity or employment objective, banker for the State, supervisory tasks, supporting the economic policies of government, to name a few), to maintain some form of price stability. Also, the instruments of policy used by a large number of central banks around the world have ranged over the decades from setting interest rates, influencing the price of gold, liquidity enhancing and credit easing measures, setting objectives for the exchange rate and money growth. The fact that one resorts to a post 1990s framework to examine central bank performance in previous decades simply means that allowances should be made for deviations from such rules. They do not, however, invalidate their use. After all, Taylor $(1993,1998)$ demonstrated the usefulness of his rule for the Fed using historical data for a period when few would have characterized monetary policy as acting in a rule-like manner. While it is true that focus on Taylor rules masks the fact that central banks over time have deployed different policy instruments, the formulations we develop below do not ignore other factors, such as money (or credit) aggregates in potentially influencing financial conditions. ${ }^{14}$

Kozicki and Tinsley (2009) explicitly demonstrate that a formulation such as (1.1) is consistent with a several policy strategies. ${ }^{15}$ Hence, describing change in central bank

\footnotetext{
${ }^{14}$ Reinhart and Rogoff (2013) point out that the Fed, like a few other central banks, have seen their mandate evolve over time, from financial stability to price stability, and back again to financial stability. Consequently, they favor a greater role for credit aggregates in the conduct of monetary policy, a point repeatedly made by the BIS in recent years. Nevertheless, their analysis underestimates the connection between price stability and financial stability as well as equating financial stability with bank stability. There is no allowance made for the role of shadow banking nor does the Federal Reserve Act explicitly define what financial stability means.

15 Their formulation is expressed in terms of an unemployment gap in part because they are interested in U.S. monetary policy during the 1970s through the late 1990s. Data restrictions as well as comparability with most of the relevant literature, including Orphanides' (2003) historical analysis of policy rules, make it impractical, in our study, to rely on the unemployment rate. Instead, we begin with a rule expressed in terms of an output gap.
} 
credibility over time in these terms is possible because central banks have different views about the various natural rates in the Taylor rule (inflation, output, and the real interest rate), as well as different attitudes about how aggressively to react to inflation and output gap shocks (i.e., the size of $\alpha_{1}, \alpha_{2}$ ). Moreover, with some exceptions, even if central banks are clear about the primary instrument of policy used to control inflation they have also always reserved the right to resort to using other instruments at their disposal. It is only very recently that many central banks have become sufficiently transparent to allow clear identification of the instruments of policy actually used.

It seems reasonable then, if we are interested in evaluating central bank credibility and reputation, to focus our attention on how expected inflation evolves over time when derived from alternative formulations of equation (1.1), conditioned on a chosen monetary policy instrument. Since we can allow estimates of expected inflation to evolve for both short-term economic reasons (e.g., an economic shock of some kind), as well as institutional reasons (e.g., a change in the degree of central bank independence), this serves as the starting point for our estimates of central bank credibility over time. As Kahn (2012) argues: "The Taylor rule can be seen as part of a broader movement in which commitment (and therefore credibility), transparency, and independence, replaced a culture of discretion, "mystique," and occasional political influence."

We begin with the case where interest rates are not smoothed and equation (1.1) augmented by a 'speed limit' term (e.g., see Woodford 2003) that corrects for measurement type errors in specification via the addition of an output growth term. Next, strong persistence in the policy rate is accounted for by permitting dynamic adjustment of the policy rate. This yields a version of (1.1) which can be written as follows

$$
i_{t}=\gamma_{1, t}+\gamma_{2, t} E_{t} \pi_{t+1}+\gamma_{3, t}\left(E_{t} y_{t+1}-y_{t}^{*}\right)+\gamma_{4, t} \Delta y_{t}+\gamma_{5, t} \Delta i_{t-1}+\gamma_{6, t}\left(i_{t-1}-\bar{\rho}_{t}\right)+\bar{\rho}_{t}+\eta_{t}
$$

Adapting the result from Kozicki and Tinsley (2009), the implied inflation target is derived as

$$
\bar{\pi}_{t}=\frac{-\gamma_{1, t}}{\left(\gamma_{2, t}+\gamma_{6, t}-1\right)}
$$


When an intermediate monetary target is in place we rely on a Quantity Theory type formulation that sets money growth $\left(\Delta m_{t}\right)$, in both realized and equilibrium terms, according to either realized or the effective inflation target, the growth rate of the economy and velocity movements $\left(\Delta v_{t}\right)$.

Kozicki and Tinsley (2009) then demonstrate that the effective inflation target can be shown to be (also, see Orphanides 2003) ${ }^{16}$

$$
\bar{\pi}_{t}=\Delta \bar{m}_{t}-\Delta \bar{y}_{t}+\Delta \bar{v}_{t}
$$

Finally, we consider the case of a small open economy that contemplates combining interest rate and exchange rate instruments in the manner of Ball (1999) so that the policy rule is expressed as an adapted version of equation (1.1) written as follows:

$$
\lambda i_{t}+(1-\lambda) e_{t}=\bar{\rho}_{t}+\bar{\pi}_{t}+\tilde{\alpha}_{2} \tilde{\pi}_{t}+\tilde{\alpha}_{3} \tilde{y}_{t}+\tilde{\varepsilon}_{i, t}
$$

where $e_{t}$ is the nominal exchange rate (i.e., the domestic price of foreign currency). Under a floating exchange rate regime, $\lambda=1$, so we are left with an expression of the form of equation (1.1). Next, if domestic and foreign inflation rates are related to each other via an (uncovered) interest rate parity relation the effective inflation target is reminiscent of equation (1.3), but adapted to capture the trade-off between an interest rate and an exchange rate response so that we obtain the following expression for the implied inflation target

$$
\bar{\pi}_{t}=\frac{-\gamma_{1, t}}{\left(\gamma_{2, t}+\gamma_{6, t}-\gamma_{7, t}-1\right)}
$$

\footnotetext{
${ }^{16}$ As a result, this formulation of the policy rule has the distinct advantage that it does not rely on unobservable output gap measures. See, for example, Friedman (1968) and Orphanides (2003). Nevertheless, the specification does require taking a stand on how best to measure the money supply. The formal expression is still as in equation (1.3) except that, in equation (1.2), $E_{t} \Delta x_{t+1}$ replaces $E_{t} \pi_{t+1}$ and $E_{t} y_{t+1}$ replaces $\Delta y_{t}$. In other words, parameters $\gamma_{3, t}$ and $\gamma_{4, t}$ are affected. $\Delta x_{t}$ is a proxy for the nominal output growth gap obtained via Okun's Law (e.g., see Ball et. al. 2013). The difficulty is that Okun's Law requires data for the unemployment rate in order to estimate the relevant gap measure and this series is likely unavailable for several countries and samples in our dataset. Instead, we proxy $\Delta x_{t}$ by estimating $\Delta \pi_{t+1}+0.454 \Delta y_{t+1}$. The 0.454 value is obtained for the U.S. from Ball et.al. (2013) and is equivalent to the value used in Kozicki and Tinsley (2009). For the other countries in the data set we also rely on estimates in Ball et. al. (2013).
} 
where $\gamma_{7, t}$ is obtained from a variant of equation (1.2) augmented by adding a term capturing the expected depreciation of the nominal exchange rate. The upshot is that not all shocks require an immediate response of the policy instrument to maintain credibility. ${ }^{17}$ Indeed, as long as the central bank communicates clearly (i.e., there is adequate transparency) ${ }^{18}$, some changes in the inflation and the output gap will elicit a response such as when the economic shock is of the aggregate demand variety while other types of shocks, namely aggregate supply shocks, are responded to in a 'balanced' fashion. Both of these actions should be reflected in the ability of the central bank to 'anchor' inflation expectations.

We can now define credibility. In the simplest terms a central bank is deemed credible when it delivers, subject to a random error, the implied inflation rate objective conditional on the monetary regime in place. Of course, as previously noted, there may well be economic and institutional reasons why the credibility of the central bank may be affected. Consequently, we write

$$
\left(\pi_{i t}-\bar{\pi}_{i t}\right)^{2}=\mathbf{\theta Z} \mathbf{Z}_{i \mathbf{t}}+\varphi_{i}\left(\pi_{i, t-1}-\bar{\pi}_{i, t-1}\right)^{2}+\mathbf{u}_{i \mathbf{t}}
$$

Where the dependent variable is our indicator of credibility, $\mathbf{\theta Z}_{\mathbf{t}}$ is the product of a vector of coefficients, $\boldsymbol{\theta}$, and $\mathbf{Z}$ represents economic and institutional variables that can explain departures from the effective inflation target (see the following section). Finally, as suggested earlier, credibility may be persistent because inflation tends to be persistent over time (e.g., Burdekin and Siklos 1999). The subscript $i$ identifies the country in question. Equation (1.7), therefore, is estimated as a panel. ${ }^{19}$ Since we are also interested in asymmetries that have consequences for central bank credibility we consider separately a

\footnotetext{
17 Indeed, as a result we do not interpret what central banks have done as if they followed an optimal control (OC) policy. Orphanides and Williams (2011) demonstrate an OC policy does not deliver better outcomes unless the information possessed by the authorities is superlative. Since this is unlikely, even in the data rich environment we live in, and almost certainly a low probability event in earlier decades, our approach is more akin to the 'robust' monetary policy type of approach in the presence of significant impairments in information.

${ }^{18}$ Clarity and transparency need not, of course, go hand in hand (e.g., see Siklos 2003).

${ }^{19}$ Space limitations prevent the extensive reporting of the sensitivity of our results to sub-sample selection. See, however, Bordo and Siklos (2014) for additional evidence which corroborates the conclusions discussed below. We consider a variety of samples based on historical evidence dating the start and end of monetary policy regimes, the length of time the various central banks in our study have been in existence, as well as limitations due to the availability of certain institutional data (e.g., index of central bank independence or transparency).
} 
version of equation (1.7) for what we term low inflation and deflation environments. Low inflation is arbitrarily defined as CPI inflation below 1.5\% while deflation, of course, obtains when inflation is negative. ${ }^{20}$

Note that credibility is independent of the level of inflation. Credibility is also independent of whether or not the central bank has other targets (e.g., money growth, exchange rate). Recall that, for reasons previously discussed, our interpretation of credibility is focused on inflation performance relative to some (implicit) inflation objective. Of course, the latter may well be indirectly influenced by performance in relation to other objectives or targets the central bank may pursue which are likely also impacted by institutional considerations. We return to this issue in the empirical section where we allow for the possibility that past inflation shocks can also impact credibility.

There exist, potentially, several questions that can be raised about specification (1.7). First, if there are any lags in obtaining and processing information then it is not clear that credibility will involve the differential between observed inflation and the contemporaneously implied inflation target. While inflation rates are observed fairly quickly it may well take some time to observe the effective inflation target. ${ }^{21}$ Of course, to some extent, the appropriateness of equation (1.7) is dependent on the sampling frequency being used. At the annual frequency, which is used in this study, the foregoing specification seems sensible.

There is no reason for the relationship between credibility and its determinants to be linear. For example, there may well be a threshold beyond which there is a loss of credibility whereas there might also exist a 'band of indifference' within which there is no appreciable loss of credibility. An alternative, commonly found the literature on policy rules and the objective function of central banks, is to assume that the loss of credibility rises with the size of the deviation from the inflation goal. A simple specification that meets this requirement is to express credibility as the squared differential between observed and

\footnotetext{
${ }^{20}$ Some judgment is involved when selecting the threshold for low inflation. However, even in the modern era where $2 \%$ inflation targets are common, the choice of a $1.5 \%$ threshold seems a reasonable one.

${ }^{21}$ In principle observing the inflation target is easier in a conventional inflation targeting (IT) regime. Recall, however, that the implied inflation target, as defined here, need not to be the same as the numerically announced inflation target. All modern IT regimes are sufficiently flexible in that they are permitted to avoid missing the target from time to time as long as departures are publicly explained. Whether these departures separately influence credibility is, of course, another matter.
} 
the Fed's inflation goal. Hence, the dependent variable is expressed as in equation (1.7). ${ }^{22}$ However, as will be seen below, other alternatives are also considered.

As noted previously, it is not always known a priori whether a central bank relies primarily on one instrument over another. Hence, estimates of (1.3) and (1.6) may well be implausible. As will be demonstrated below this means that there is some value in censoring 'outliers' based on estimates of (1.7).

\subsection{Challenges in Measuring Credibility Over A Long Time Span}

Obviously, there are a number of complications when dealing with historical data especially when the span of time exceeds over a century of data. In no particular order of importance one might include significant changes in the quality, scope and availability of time series useful for the kind of macroeconomic analysis in place. Consequently, the evidence marshaled below is cross-checked with additional narrative evidence about the evolution of central bank credibility over time.

An additional illustration of the desirability of blending the time series econometric approach with what is known from economic history emerges when evidence that a change in the monetary policy regime is found. If such an event is associated with, say, a sudden loss of credibility then our estimates should compare favorably with historical depictions of a policy regime change. Econometrically, these could be identified from structural break tests. Of course, structural breaks come in many forms. For example, it is interesting to examine the connection between financial crises and changes in central bank reputation and credibility. The global financial crisis of 2008-9 has been said to rest on the ineffectiveness of financial regulation and supervision by the Fed and other regulators, on the Fed keeping policy rates too low to fight the prospect of deflation, and on the inattention of central bankers to the possible link between low inflation and asset price booms leading to financial sector instability. ${ }^{23}$

\footnotetext{
${ }^{22}$ Indeed, if credibility is only a function of whether observed and the notional inflation objective are different from each other, so that we set $\mathbf{\theta Z}_{i t}=\mathbf{0}$, and $\mathbf{u}_{i t} \sim N\left(0, \sigma_{i u}^{2}\right)$, then credibility can be interpreted as observed inflation and the effective inflation objective being attracted to each other in the sense of being cointegrated. We do not, however, investigate this possibility here.

${ }^{23}$ Bernanke (2013, p. 23) admits as much. “...the Federal Reserve failed [to] ...adequately perform its function as lender of last resort...".
} 
As the foregoing discussion indicates the lender of last resort (LOLR) function of central banks is critical. Long dormant as the growth in the financial sector provided adequate liquidity until the loss of confidence in 2007-2008, the re-emergence of the LOLR role of central banks was ushered in by market failures in key financial markets. Finally, the combination of statistical testing and the narrative approach should also reduce the likelihood of identifying too many breaks. ${ }^{24}$

\section{Data and Methodological Considerations}

Our empirical investigation consists of a time series analysis of 10 central banks around the world. ${ }^{25}$ They are: Canada, France, Japan, Germany, Italy, Norway, Sweden, Switzerland, the U.K. and the U.S. We rely on annual data going back to when central banks were established. Table 1 provides information about the year when the central banks in our sample were created as well as a brief description of the proximate reason for their creation. It is interesting to note that, of the central banks surveyed, not all were created to fulfill the lender of last resort mandate. Indeed, other than to assist with the consequences of war finance, monetary stability is the other major proximate explanation for the creation of many central banks around the world. Since their formation central banks, and central banking more generally, have seen a broadening of their functions while shouldering ever greater responsibilities for economic stabilization.

For several countries in our sample (e.g., Japan, Norway, the U.K., Sweden) we can rely on over a century of data. For other countries (e.g., the U.S.) annual data span almost a century of data. There is a rich historical narrative history to draw on to identify policy regimes, exchange rate regimes, the dating and identification of crises (e.g., see Bordo, Eichengreen, et. al. 2001, Reinhart and Rogoff 2009, Bordo and Orphanides 2013, Singleton 2012, James 2012, just to name a few). Moreover, thanks to efforts made by several central banks to greatly improve historical data sources (e.g., Norway) there are ample macroeconomic and financial data. In other cases (e.g., Canada and the U.S.) there is a long

\footnotetext{
${ }^{24}$ In a sense this was the aim of Perron's (1989) seminal contribution to the literature on the time series properties of macroeconomic data. Hence, not all shifts in time series are permanent (i.e., level or intercept shifts). Indeed, some breaks simply alter the trend in a time series.

${ }^{25}$ Narratives were written for all of these central banks except Japan. The narratives also include the Reserve Bank of Australia and New Zealand.
} 
tradition of collecting historical time series and making them publicly available. To these sources must be added the sources of data the authors and their collaborators, as well as others, have compiled over the years. Finally, Global Financial Data (https://www.globalfinancialdata.com/index.html) is another source of long-term macroeconomic and financial data, especially for countries in Europe and Asia where publicly available historical time series are more difficult to obtain.

Prior to econometric estimation three preliminary steps are followed. First, either based on statistical testing or using the narrative approach, we must identify policy regimes. Since we estimate a central bank's inflation objective under the assumption that the same policy instrument is used throughout the estimated sample, it is inevitable that we end up adopting a counterfactual approach, at least for a portion of the sample in question. Consequently, one may view this approach as asking whether some monetary regimes are more credible than others over time. In a second step, equation (1.2), or its variants, are estimated to obtain the key parameters of interest, namely $\gamma_{2, t}, \gamma_{6, t}$, and $\gamma_{7, t}$. Finally, we can obtain estimates of the implicit inflation target, $\bar{\pi}_{t}$, for each central bank. Notice that the parameters and the inflation objective are time-varying as are the estimates of the real policy rates. There exist, of course, a variety of techniques to generate such estimates. As discussed in the results section we also combine several proxies to improve the robustness of our estimates.

Credibility and, by implication, reputation might also be determined by governance structures that define the relationship between the central bank and government, including central bank independence. In this case we can resort to data originally constructed by Cukierman (1992), updated by Siklos (2002), with more recent data also available from the IMF (e.g., see Arnone and Romelli 2012, and Arnone et. al. 2009). However, these data are only available since the 1950 s.

\section{Empirical Evidence}

\subsection{Panel Estimates}

Relying on the notion that the average of forecasts delivers superior performance relative to individual forecasts our estimates of expected inflation are based on mean 
forecasts generated from three different models. ${ }^{26}$ First, we evaluate the three years ahead mean inflation rate, that is, $E_{t} \pi_{t+1}=\left(\pi_{t+1}+\pi_{t+2}+\pi_{t+3}\right) / 3$. Next, we estimate an AR(1) model for observed inflation and let the data select up as many breaks based on a series of econometrically determined constraints. ${ }^{27}$

Finally, following Stock and Watson (2007) we estimate an integrated moving average model of order 1 (i.e., an IMA(1,1)) in the change in inflation as this has been shown to be a reliable inflation forecasting model in a wide variety of circumstances. In a twist on the usual approach, however, the IMA(1,1) model is separately estimated for each sub-sample obtained from the analysis of breaks in the inflation process using an AR(1) model. This approach provides us with additional insights into the changing role of permanent versus transitory shocks influencing the behavior of inflation since the time the central banks in this study were founded. 28

As with the proxy for expected inflation, the output gap measure used below is the mean of several proxies. They are: an H-P filter with the standard smoothing parameter (i.e., 100 in the case of annual data), two other versions of an H-P filter estimated with a 20 year window and changing end-points (one fixing the end-point at the beginning of the sample, the other fixing it at the end of the sample) and, finally, deviations from a linear trend applied to the logarithm of potential real GDP allowing for break-points beginning around the time of the Great Depression, one that starts at the time of the first oil price shock of the 1970s, and a final one at the end of the sample to capture the early stages of

\footnotetext{
${ }^{26}$ Obviously in a study that looks at credibility for roughly a century of data we are unable to construct a data set consisting of private sector, central bank or survey data that covers the entire span of the history of the Fed or, for that matter, any of the other central banks in our study. We also considered a fourth models, namely the difference between the yield on a long-term government bond and a ten year (moving) average of inflation (e.g., see Bordo and Dewald 2001). However, as the results were unaffected we did not include them in computing the final estimate of inflation expectations.

27 This involves implementing the Bai-Perron (1998) test where the maximum number of breaks we restrict is set according to the rule $\mathrm{T} / 25$, where $\mathrm{T}$ is the number of available observations. In this manner we restrict the maximum number of structural breaks to, at most, 4 per century of data. The breaks are globally determined and a degrees of freedom adjustment is also applied. The samples are 'trimmed' using a $10 \%$ rule meaning that breaks will be located in $80 \%$ of the sample excluding the first and last $10 \%$ of the sample. It is well-known that these choices in the estimation of breaks will impact their frequency and location. This is another reason for cross-checking the choice of breaks with the historical evidence.

${ }^{28}$ The samples are defined so that the year a structural break is found in the Bai-Perron test is the last observation of each sub-sample. Additional robustness tests were conducted when the sub-samples were short (e.g., less than 15 years in duration). Stock and Watson (2007) also indicate that permitting some time variation in this kind of model improves the forecasting performance of this model.
} 
the so-called Global Financial Crisis. ${ }^{29}$ The difficulties in estimating the output gap have been widely discussed. Admittedly, the task of estimating an indicator of economic slack is made even more difficult when a century of data is examined. However, as pointed out in Goodfriend and King (2013), if the output gap properly measures aggregate economic slack then it should be negatively correlated with future real GDP growth. ${ }^{30}$ This seems to be the case for the proxy generated here, at least beginning around the mid-1920s (results not shown).

Next, we consider the institutional determinants of credibility. As discussed previously, our benchmark measure of credibility is evaluated as the squared deviation from a central bank's inflation objective. Other measures were considered, including distinguishing between instances when observed inflation is above as opposed to being below the central bank's inflation goal. We then consider some hypothesized institutional determinants at our disposal. Accordingly, $\mathbf{z}_{i t}$, the vector of institutional determinants of credibility is specified as follows:

$$
\mathbf{Z}_{i t}=\left[\text { Gold }_{i t}, \dot{M}_{i t}, \text { loans }_{i t}, \text { debt }_{i t}, \text { OIL }_{i t}, C R I S I S_{i t}, C B I_{i t}, E R R_{i t}\right]
$$

where Gold is a dummy variable that identifies when country $i$ was on the Gold standard, $\dot{M}_{i t}$ is the growth rate of a broad monetary aggregate, loans represents the ratio of bank credit to GDP, and debt is the ratio of sovereign debt to GDP. Other controls include a dummy variable for the oil price shocks of the 1970s, CRISIS are dummy variables to capture various financial crises (banking, currency, stock market and/or sovereign debt of the domestic or external varieties), $C B I$ is an index of central bank independence while $E R R$ is a dummy indicative of the type of exchange rate regime in place. ${ }^{31}$

An obvious concern, among others, is that some of the determinants of credibility may be endogenous, reflecting both the impact of past credibility and, in turn, influencing future central bank credibility. This concern is considerably mitigated under the circumstances either because lags are used, the persistence properties of credibility are

\footnotetext{
29 The break for the Depression begins in 1930 and is defined as an intercept break, the other two are slope breaks which begin in 1974 (oil price shocks) and 2006 (global financial crisis).

${ }^{30}$ A positive output gap signifies real GDP is above potential or trend real GDP. If the economy stabilizes around the trend over time then observed real GDP should eventually fall towards trend. Hence, a positive output gap should be associated with lower future real GDP growth.

${ }^{31}$ Data are only available since the 1950s for CBI and mid 1940s for ERR.
} 
recognized, and the economic determinants listed above are likely to influence credibility instead of the other way around. Equation (1.7) is estimated using GLS in a panel setting. ${ }^{32}$ Given the wide-ranging inflation experiences of the 10 countries in our sample (see below) we apply cross-section weights as well as estimate heteroskedasticity-consistent standard errors. ${ }^{33}$

Figure 1 provides a summary description of the inflation history of the 10 countries in the sample. The boxplots allow easy visualization of the differences between mean and median inflation rates, identification of outliers, and the range of inflationary experiences in each country. One immediately notices that outliers tend to be positive not negative. That is, high inflation rates are far more likely to have been experienced than high rates of deflation. As a result, it is not surprising that median inflation rates (the bar inside the box) are always below mean inflation rates. For the most part, however, the differences between the two are small. Indeed, both mean and median inflation rates through time have tended to be less than $5 \%$. The box, which provides an indication of the range of inflation rates between the first and third quartiles (i.e., $75 \%$ of the distribution of inflation rates) tends to be rather narrow. This suggests that while variations in inflation rates throughout history have been large the vast majority of the range of inflationary experience in the 10 countries examined here has been relatively small. Nevertheless, it is notable that negative inflation rates have occurred in all countries during the course of their experience with central banking. We return to this issue below (see Figure 3). Even if one excludes outliers from the analysis (see below) double digit inflation rates are not uncommon with the exception

\footnotetext{
32 With the limited number of instruments we also estimate the same specification using GMM. Typically, we use lagged values of the variables shown above although a few additional variables (e.g., lagged inflation, money growth) are also candidates. The conclusions discussed below hold when instrumental variable techniques are applied but the results, perhaps unsurprisingly, can be highly sensitive to the choice of instruments. Our metric for whether the instruments are adequate is the Stock-Yogo test (e.g., see Stock and Yogo 2005). Essentially, a linear regression of the variable suspected of being endogenous on the collection of instruments must yield an F-test statistic of at least 10, as a rule of thumb. In practice more formal tests were used to assess the weakness of the chosen instruments.

${ }^{33}$ It is possible that some of the determinants (e.g., the CRISIS dummies) interact with others (e.g., debt to GDP ratio). Therefore, we also consider interaction terms. However, as none of the main conclusions were affected, we omit interaction terms in the specifications presented below. See, however, Bordo and Siklos (2014) who include interaction terms.
} 
of Germany, Switzerland, and the USA. ${ }^{34}$ Similarly, Japan does not stand out when it comes to experience with deflation. Indeed, the deflation profile for Japan looks similar to that of Norway's and Sweden's.

Not shown are some data that pertain to the performance of the inflation expectations data compared to observed inflation. We find that the higher is observed inflation the potential for forecast errors also rises. Hence, as one would expect, it is more difficult to forecast high inflation rates than when inflation is low. Consequently, one expects that it is relatively easier to anchor low inflation rates. To the extent that these expectations errors contribute to changing credibility the data suggest considerable scope for central bank credibility to change over time. ${ }^{35}$

Figure 2 plots instances when inflation rates are low or negative. Recent events make clear that central bankers are just as concerned with low positive inflation rates as they are about the prospect of deflation. While the choice of a threshold between low and some acceptable inflation rate is admittedly ad hoc we have chosen to define low inflation as observed inflation rates below 1.5\%. Deflations tend to be observed before World War II and this includes Japan. Indeed, by historical standards the recent two decades or so encounter with deflation is rather mild relative to the pre World War II experience. Indeed, negative inflation rates, though not unheard after 1950, are dwarfed by examples from before World War II, most notably when the Gold Standard was operational. However, for the U.S., where we have independent evidence of recessions versus expansions (i.e., the NBER business cycle chronology), the stylized facts do not appear to suggest that low inflation or deflation are strongly correlated with recessions. Canada is another country where we also have an NBER style recession indicator (Cross and Bergevin 2012). Once again, there is no obvious visual relationship between low inflation, deflation, and recessions.

Next, we move on to an analysis of the determinants of credibility based on estimates of equation (1.7). The results are summarized in Table 2 as well as in Figures 3

\footnotetext{
${ }^{34}$ Note that data for Germany excludes certain periods because the data are incomplete or, in the case of Germany's experience with hyperinflation, would not provide any useful insights about credibility under such extreme conditions.

${ }^{35}$ Recall that the expectations proxy is partially based on estimates of structural breaks in inflation performance. The Appendix provides a list of the estimated break-point dates.
} 
and 4. To economize on space, Table 2 shows the estimated panel coefficients for the vector $\mathbf{Z}_{\mathbf{i t}}$ described above. Although fixed effects were added in virtually every case (test statistics for the redundancy of fixed effects are also provided) these are not shown. Estimates are shown for two samples and four cases. The choice of samples is partially dictated by data availability, as in the indicators of central bank independence and exchange rate regime type, as well as the earlier observation that the behavior of inflation rates before World War II appears different from the period since that conflict ended.

The three cases considered are also meant to control for the potential impact that outliers might have on the results. For example, if credibility is particularly vulnerable when inflation rates are very large, and such events are also associated with financial crises, then trimming the data set to exclude outliers should provide additional insights into the factors that drive credibility. Consequently, the trimmed estimates exclude deflations that exceed $-5 \%$ as well as inflation rates of more than $15 \% .{ }^{36} \mathrm{Next}$, we consider a variant of equation (1.7) where deviations from the central bank's implicit inflation objective are not squared but, instead, we separately examine positive versus negative deviations from the model-based inflation targets used to proxy the time-varying inflation objective. Finally, since our definition of credibility is independent of the level of inflation, we also consider a version of equation (1.7) augmented with a variable which asks whether credibility is affected by the interaction of inflation expectations surprises (i.e., the difference between observed and expected inflation - not the central bank's inflation objective) and a dummy variable that identifies positive inflation shocks (i.e., instances where the change in observed inflation is positive). A statistically significant response would indicate yet another avenue through which there are asymmetric effects on credibility. In particular, we can determine whether positive inflation shocks, combined with the size of the forecast error, contribute an additional and, presumably, negative effect on credibility.

Table 2 shows the coefficient estimates for the variables in $\mathbf{Z}_{\text {it }}$ as well as a few summary statistics while Figure 3 graphically displays the estimates of the persistence of credibility in the 10 countries considered (i.e., the coefficient $\varphi_{i}$ ). We find that if an interest

${ }^{36}$ The appendix provides information about the impact on sample size from the exclusion of 'outliers'. 
rate instrument is used the Gold Standard period reliably improves central bank credibility since the negative sign suggests that the squared gap between observed and goal inflation becomes smaller. Perhaps more interesting is the finding that when a financial crisis is present this reduces credibility with the effect significantly larger in the post-war era. Notice, however, that the effect disappears when we trim the distribution of inflation rates as defined above. It appears, therefore, that a financial crisis together with a bad inflation outcome contributes to significantly erode central bank credibility. ${ }^{37}$ Otherwise, there is no separate statistically significant impact of financial crises on central bank credibility. There is also some evidence that oil price shocks negatively impact credibility. This is not surprising since, if such events reflect a rise in observed inflation even when the central bank's inflation objective remains unchanged. ${ }^{38} \mathrm{~A}$ reading of the international response to the oil prices shocks of the 1970s (see Bordo and Orphanides 2013) seems consistent with the view of a loss of credibility as a result of the oil shock of the 1970s.

Finally, if we examine the determinants of credibility since the 1950s, we find that central bank independence does indeed improve credibility. However, this result only obtains when we rely on the trimmed data. Consequently, central bank independence does not help when there are episodes of unusually high inflation rates. There is also a little bit of evidence that the impact of autonomy is asymmetric with the effect more pronounced when inflation is below the monetary authority's implicit inflation objective than when observed inflation is relatively higher than the goal set by the central banks.

Turning to the case of a money supply target we find more muted evidence of the credibility-inducing benefits of the Gold standard. In addition, the impact of the determinants in $\mathbf{Z}_{\text {it }}$ appears to be relatively more asymmetric in nature when the money supply is targeted than when an interest rate instrument is assumed. For example, we find that rises in private sector credit and government debt to GDP ratios reduce credibility but only when we consider episodes where inflation is below the central bank's implicit inflation objective. Similarly, central bank independence improves credibility but,

\footnotetext{
${ }^{37}$ As previously noted, we have several proxies for financial crises depending on their source. Although we experimented with each measure separately the most reliable results are obtained when financial crises are aggregated. Hence, in what follows, the financial crisis dummy refers to the sum of all types of financial crises defined earlier.

${ }^{38}$ We also experimented with a time series of oil prices going back to the mid-19 ${ }^{\text {th }}$ century but this did not improve the results.
} 
interestingly, the impact is relatively larger when inflation exceeds the central bank's goal than vice-versa. Finally, in contrast with the case where an interest rate instrument is used, financial crises appear to only weakly impact credibility and again only when inflation is above target.

Part $\mathrm{C}$ of Table 2 considers the case of the exchange rate instrument. The Gold Standard once again is a device that enhances central bank credibility while central bank independence is also seen to consistently raise credibility. Oil price shocks also appear to have a negative effect on credibility as do financial crises. Unlike the other two instruments considered, rising equity returns help raise central bank credibility. Somewhat counterintuitively there is solid evidence that higher government debt to GDP ratios improve credibility. Whether this reflects an expectation that central banks will not allow such a development to raise their inflation objective we cannot say. Nevertheless, it is worth adding that the coefficients are economically small and are easily dwarfed, for example, by the impact of central bank independence on credibility.

Figure 3 stacks the coefficient estimates of the lagged dependent variable in (1.7) which serves as an indicator of credibility persistence. Although there is no sign or size restriction on the parameter of interest, if the maximum value in absolute terms is close to one while the minimum value is zero then the vertical axis is defined such that it ranges between zero and ten. To identify the coefficient estimate for each country one simply needs to subtract a particular value shown in the figure less its value in the bar immediately below. ${ }^{39}$ Not surprisingly, there is less persistence when all data are considered than when we trim the inflation data to exclude large inflation and deflation rates. Nevertheless, cross-country differences are most noticeable for the full sample than when the post-war data are separately considered. Next, it appears that persistence is sensitive according to whether we proxy credibility as in equation (1.7) or by separately examining positive versus negative values of the difference between inflation and the central bank's objective for inflation. Also, the total amount of persistence is roughly the same regardless whether the chosen instrument of monetary policy is an interest rate, a growth rate in the money supply or the exchange rate. To be sure, there are noticeable

\footnotetext{
${ }^{39}$ For example, in part A of the Figure, the top of the first bar indicates 4.5, the second 4.0. Hence, the estimate of credibility persistence for the Fed for the full sample (1914-2008 in the Fed's case) is 4.5-4.0=0.5.
} 
cross-country differences. These are seen by looking at the height of each bar in Figure 3. Nevertheless, the most robust estimates are ones obtained when the data are trimmed. Overall then, to obtain a clear picture of the determinants of credibility it is advisable to trim the data. The only caveat is that if one seeks confirmation that the interaction of financial crises with historically high inflation or deflation rates reduces credibility then it is necessary to use all the available data at our disposal (see Table 2).

Finally, Figure 4 uses a bar chart to display the coefficient indicating how the interaction of a positive inflation shock (i.e., a dummy equal to 1 when the change of inflation is positive) and forecast errors impact central bank credibility. ${ }^{40}$ With the exception of Germany, positive shocks do indeed reduce credibility defined as in equation (1.7). Note, however, that the credibility impact is sensitive not only to the chosen sample but to the chosen monetary policy instrument. For example, in Switzerland's case, the reduction in credibility following an inflation shock is considerably larger when an interest rate instrument is assumed. In the case of Norway, the impact on credibility is much larger when an exchange rate instrument is assumed. As far as Germany is concerned one can only assume that positive inflation shocks improve credibility if the public is convinced that the central bank will react appropriately to prevent persistent rises in inflation. Of course, we have no way of knowing whether this is the only hypothesis consistent with the data other than to rely on the historical experience of the Bundesbank. Even if the estimates coefficients are relatively small compared to the ones found statistically significant in Table 2 there is some evidence that the level of inflation, particularly when it is rising, does have an independent influence on central bank credibility.

5.2

Select

Individual

Country

Evidence

Ideally, we would have liked to discuss every country in the sample but space limitations prevent us from doing so. We note, however, that in addition to the evidence presented below the evidence, the case of Japan suggests that the patterns of the gain or loss of credibility mirrors the experience of most of the other countries considered below,since the early to mid 1990s, there has been a persistent loss of credibility for the Bank of Japan.

\footnotetext{
${ }^{40}$ Complete estimates are relegated to the appendix. Note that the addition of this variable did not alter the conclusions based on Table 2. We also considered other variants such as adding the level of inflation, and the change in observed inflation. Generally speaking, the conclusions are similar to the ones described below.
} 
Indeed, when an interest rate instrument is assumed to be used to conduct monetary policy there is evidence of rising credibility losses until the end of the sample (2008). Rolling estimates point in the same direction though the most notable negative shock to credibility takes place in the early 1990s. Nevertheless, large credibility losses have taken place earlier in the Bank of Japan's history such as shortly after the end of World War II and during the brief but significant surge in the 1970s especially following the first oil shock of that decade.

\subsubsection{United States}

We begin with a description of some broad stylized facts. Figure $5 \mathrm{~A}$ plots observed CPI inflation since the creation of the Fed together with our estimate of expected inflation. In this manner we identified four breaks: in 1924, 1933, 1973, and 1982. An ex post historical analysis suggests that the location of these breaks appear sensible. The first break occurs after the deflation of the early 1920s and when the Fed became more activist; the second break takes place when the monetary authorities implemented a more comprehensive response to the Great Depression. The break in 1973 is, of course, associated with the first oil price shock while the break in 1982 can be explained by the Volcker disinflation policy.

One hopes, of course, that inflation expectations track observed inflation. Nevertheless, there are gaps that occasionally persist over several years. This is particularly noticeable during the period of the Great Inflation (also see Bordo and Orphanides 2013) of the 1960s and 1970s. Another observation, also commonly encountered in the more recent literature on the behavior of inflation forecasts, is that inflation is more volatile than its expectation. As a result, expectation errors are short-lived but typically far greater, for example, before World War II than say during the period of the Great Moderation from the mid-1980s until the end of the available sample.

Figure 6A indicates the years when the U.S. faced an environment of low inflation and deflation. Approximately a quarter of the Fed's existence is associated with low or negative inflation with episodes of low inflation a post-World War II phenomenon while deflation is more typical of the pre-1940s macroeconomic experience. Moreover, based on the NBER chronology, no one to one association between low inflation or deflation and recessions is found. This view is heavily skewed by the events of the Great Depression. 
Figures 7A(i) and (ii) plot two different versions of our measure of central bank credibility (i.e., the left hand side of equation (1.7)). The recursive estimates are based on equation (1.3) estimates of $\pi_{t}-\bar{\pi}_{t}$. Since the weight of the last observation declines under the recursive scheme it is conceivable that our proxy for central bank credibility will too readily fluctuate with observed inflation as we approach the end of the available sample. Therefore, we also consider a measure of credibility based on rolling estimates of $\bar{\pi}_{t}$ using a 20 year window for the calculations. The solid lines in Figure XXX plot the recursive estimates while the vertical bars represent the rolling estimates.

When the instrument of monetary policy is assumed to be an interest rate we observe that our measure of credibility, no matter how it is estimated, is fairly close to zero during much of the Fed's history. This indicates that observed inflation and the Fed's inflation goal are fairly closely matched. Nevertheless, there are notable exceptions to this rule. The first takes place during the second half of the 1930s. This is the period when the Fed was attempting a return to a more 'normal' monetary policy following the Great Depression. Combined with an overly restrictive fiscal policy, in hindsight, these events combined to negatively impact the Fed's credibility. The next substantial period of reduced Fed credibility takes place during the second half of the 1960s, that is, when, again looking back, the Fed lost the battle against inflation with the consequent loss of reputation under Arthur Burns who went on to lament the high inflation in The Anguish of Central Banking (1979). The final episode of credibility loss takes place during the early 1980s. This period overlaps, of course, with the wrenching disinflation of the early 1980s. As Volcker himself later noted (see Silber 2012), the Fed had little credibility at the time of the temporary switch from interest rate to reserves targeting. Rising credibility would come later and benefit Volcker's successors, Alan Greenspan and Ben Bernanke. The Great Moderation is seen, therefore, as a period of high Fed credibility.

The story is much the same when we assume the Fed operates with a money growth instrument. The precise years when the Fed loses credibility in a significant way do not, of course, exactly match those of the interest rate instrument case but they come close. One interesting departure of sorts is that the money growth instrument case reveals a significant loss of credibility during the mid 1920s no doubt the culmination of the residual 
effects of the deflation of the early 1920s and perhaps even reflects attempts by the Congress, through the so-called Stabilization Bills, to require the Fed to target the price level rather than adhere strictly to the gold standard(e.g., see Siklos 2002). It is also difficult to argue that the loss of credibility shown in the late 1980s and early 1990s can be explained by residual effects of the Volcker era. The fed funds rate was, by then, the principal instrument of policy. What the result suggests then is that, had a money growth instrument been used, observed inflation would have been permitted to rise substantially above the Fed's inflation goal. Once again, a retrospective analysis suggests that the confluence of two events, namely the severe recession of the early 1990s may well have also contributed to reducing the Fed's credibility under the circumstances.

\subsubsection{United Kingdom}

Data limitations prevent us from examining the credibility record of the Bank of England since its inception. ${ }^{41}$ As is the case for most of the advanced economies in our dataset, the UK experiences relatively volatile inflation prior to World War II. The post WWII period is notable for a steady rise in inflation which reaches $20 \%$ by the early 1970 s in part as a result of the first oil price shocks as well as other macroeconomic problems that were accumulating prior to the Thatcher years. Thereafter there is a steady fall in inflation with inflation relatively low and stable especially once the inflation targeting regime is in place. Our estimates of expected inflation appear to be unable to capture the volatile movements of prices prior to WWII whereas, in the postwar period, expected inflation appears to be persistently above observed inflation. These observations will impact our estimates of the Bank of England's credibility. Not shown in the Figure are the five estimated breaks in the inflation process. These were found in 1908, 1922, 1936, 1963, and 1977. Some of the breaks are associated with financial stresses related to currency crises, or the sharp deflation in the aftermath of World War I while the most recent breaks are associated with the impact of macroeconomic policies in the UK as well as the oil price shocks.

\footnotetext{
${ }^{41}$ We are, however, able to conduct a variety of tests on inflation for the full history of the Bank. Unless otherwise stated our conclusions for the post 1870s period are unchanged. Space limitations prevent a fuller discussion here.
} 
Figure 6B plots years of low inflation and deflation in the UK. Although most of the episodes we identify take place before WWII there are a few years of low inflation in the postwar era. It is also notable that deflationary episodes are persistent particularly during the years before 1897 when deflationary shocks to the global gold market prevailed.

Finally, Figure 7B displays our estimates of credibility for each one of the three instruments. The results across the various instruments are broadly comparable. Nevertheless, it is interesting to note that while observed inflation is often lower than the Bank of England's inflation objective, as derived from our estimated models, the reverse is true beginning in the 1940s. Moreover, whereas there is little persistence in the estimates of credibility before the 1930s credibility losses are persistent and rise throughout much of the post WWII era, that is, until the end of the sample when the Bank of England's inflation objective and observed inflation become closely matched. It is tempting, but cannot be proven, that the adoption of inflation targets contributes to this result. Finally, rollingbased estimates support the inferences based on the recursive estimates.

\subsubsection{Germany}

Figure 5C plots inflation and our proxy for expected inflation for Germany. Note that the gap is dictated by gaps in the data due to the two World Wars as well as the deliberate omission of the hyperinflation of the early 1920s. It is also worth bearing in mind that inflation is likely to be affected, as is the credibility of the Bundesbank by the various phases towards the adoption of the euro in 2001. ${ }^{42}$ Although inflation is volatile in the pre 1910 era, at least compared with inflation in the post WWII period, the record of low German inflation is clearly visible. As a result, and paralleling the results for the other cases examined in this paper, our proxy for expected inflation does a poorer job of matching observed inflation when inflation is volatile than when volatility is low. A time series analysis of breaks in inflation dates these as follows: 1896, 1914, 1970, and 1984. One of the breaks is clearly associated with the start of World War I and is found at the end of the first sample (i.e., before the gap in the data),the 1896 break occurs at the inflexion point between gold deflation and inflation. The 1970 break can be explained by the collapse of the Bretton Woods System. The 1984 break does not appear to be directly associated with

\footnotetext{
42 The estimates presented in the Figures for Germany rely on separate pre and post gap models of German
} inflation. We also estimated credibility for the 'full' sample but our conclusions were largely unaffected. 
economic events. Also of interest is that the usual finding of oil price shocks influencing the behavior of inflation is not evident in the German data.

Figure 6C shows the years when inflation was low or deflation emerged. Actual periods of deflation generally take place in the late $19^{\text {th }}$ century associated with the vagaries of the gold standard and there is considerable persistence in deflation during this period. At the other end of the sample, Germany unlike many other economies examined in this paper experiences persistently low inflation right up to and after the adoption of the euro. Indeed, Germany's record of low and stable inflation is quite noticeable in the Figure.

Finally, Figure 7C displays our estimates of credibility in Germany. In spite of the deflation that persists throughout the late $19^{\text {th }}$ century, differences between the Reichsbank's inflation objective and observed inflation are small and do not persist. With few exceptions this result holds regardless of the instrument assumed to be used. Note, however, that there are more volatile changes in credibility when an exchange rate instrument is assumed. Indeed, as World War I approaches there are sharp differences between inflation and the central bank's objective especially when the rolling estimates are considered.

Turning to the post WWII era, one's assumption about the instrument of monetary policy used has considerable impact on our interpretation of Bundesbank credibility. Hence, when an interest rate instrument is operative, there are fairly large swings in credibility especially around the time of the two oil price shocks. In contrast, when a money growth instrument is employed, the type of instrument actually used by the central bank, observed inflation is found to be considerably lower than the Bundesbank's inflation objective particularly around the time of German reunification (i.e., 1989). It is conceivable then that while the public may have expected inflation to rise the German central bank held its inflation 'target'. This is consistent with the narrative in Beyer et al (2013). By the beginning of the first decade of the 2000s observed and targeted inflation closely match each other.

\section{Conclusions}

This paper seeks to determine how central bank credibility and reputation have changed over time in a cross-section of central banks around the world. Theory links 
credibility with how well the central bank is able to anchor inflation expectations relative to some implicit target over time that is allowed to change over time. In addition, there are institutional factors that also impact a central bank's credibility.

We find credibility changes over time are frequent and can be significant. Second, the frequency with which the world economy experiences economic and financial crises, institutional factors (i.e., the quality of governance) plays an important role in preventing a loss of credibility. Third, institutional factors affect credibility. For example, the Gold Standard improves credibility as does central bank independence. Finally, credibility is significantly affected according to whether the shock can be associated with policy errors. Bernanke (2013, p. 23), for example, has acknowledged that such errors can, for example, an important role in explaining the severity of the most recent 'global' financial crisis.

Our interest in credibility in central banking goes beyond the analysis of the experience of individual countries. Indeed, as is clear, for example, from the spread of inflation targeting as the monetary policy regime of choice in several countries beginning in the 1990s, or the linking of economies through pegged or managed exchange rate regimes, spillover effects can also play a role. Alternatively, changes in central bank credibility may contain an element of contagion. For example, a policy regime change in a core economy (e.g., the U.S.) may influence economic outcomes elsewhere. Consequently, there is scope for credibility effects to be imported from or exported to other economies over time. Changes in policy regimes may also occur via a simple demonstration effect not associated with any fundamental economic factors but simply because they appear to work elsewhere. One example often used to underscore this point is the Volcker era at the Fed (e.g., see Silber 2012). Another is the dominant position of the Bank of England in the classical gold standard (Bordo 1981). Empirically, it is certainly of interest to explore these issues. However, space constraints prevent us from directly addressing the relevant implications. This is left for future research. 


\section{References}

Ahamed, L. (2009), Lords of Finance (New York: The Penguin Press).

Altug, S., and F. Canova (2013), "Do Institutions and Culture Matter for Business Cycles?”, working paper, European University Institute, March.

Arnone, M., and D. Romelli (2012), "Dynamic Central Bank Independence Indices and Inflation Rates: A New Empirical Explanation", Paolo Baffi Centre Research Paper No. 2012-118.

Arnone, M., B. Laurens, S. Segolato, and J-F. Sommer (2009), “Central Bank Autonomy: Lessons from Global Trends", IMF Staff Papers 56 (2):263-296.

Bai, J., and P. Perron (1998), "Estimating and Testing Linear Models with Multiple Strcutural Changes", Econometrica 66 (January): 47-78.

Ball, L,. D. Leigh, and P. Loungani (2013), “Okun's Law: Fit at Fifty?”, NBER working paper 18688, January.

Bernanke, B. (2013), "The Federal Reserve and the Financial Crisis" (Princeton, N.J.: Pricenton University Press).

Beyer, A., V. Gaspar, C. Gerbeding, and O. Issing (2013), "Opting Out of the Great Inflation: German Monetary Policy After the Break Down of Bretton Woods", in M.D. Bordo and A. Orphanides (Eds.), The Great Inflation: The Modern Rebirth of Central Banking (Chicago: University of Chicago Press).

Blinder, A. S. (1999), Central Banking in Theory and Practice (Cambridge, Mass.: The MIT Press).

Blinder, A., and J. Rudd (2013), "The Supply-Shock Explanation of the Great Stagflation Revisited", in M.D. Bordo and A. Orphanides (Eds), The Great Inflation: The Modern Rebirth of Central Banking (Chicago: University of Chicago Press).

Bordo, M.D. and A. Orphanides (2013), The Great Inflation: The Modern Rebirth of Central Banking (Chicago: University of Chicago Press).

Bordo, M.D., and R. MacDonald (2012), Credibility and the International Monetary Regime. New York: Cambridge University Press

Bordo, M.D., and J. Haubrich (2010), "Credit Crises, Money and Contractions: An Historical View", Journal of Monetary Economics 57: 1-18.

Bordo M.D., B. Eichengreen, D. Klingebiel and M. Soledad Martinez -Peria ( 2001) 'Is the Crisis Problem Growing More Severe?" Economic Policy. April. 
Bordo, M.D. and A.J. Schwartz (1996), "The Operation of the Specie Standard: Evidence for Core and Peripheral Countries, 1880-1990" in Barry Eichengreen and Bordo, Michael and Finn Kydland (1995), "The Gold Standard as a Rule: An Essay in Exploration", Explorations in Economic History 32: 422-464.

Bordo, M.D. (1981), The Classical Gold Standard: Some Lessons For Today" Federal Reserve Bank of St. Louis Review.

Borio, C. (2013), "Rethinking Potential Output: Embedding Information About the Financial Cycle", BIS working paper 404, February.

Borio, C., and A.J. Filardo (2004), "Looking Back at the International Deflation Record", North American Journal of Economics and Finance 15 (December): 287-311.

Braga de Macedo, J. , Historical Perspectives on the Gold Standard: Portugal and the World (London: Routledge).

Burdekin, R.C.K., and P.L. Siklos, Eds. (2004), Deflation: Current and Historical Perspectives (Cambridge: Cambridge University Press).

Burdekin, R.C.K., and P.L. Siklos (2004a), "Fears of Deflation and the Role of Monetary Policy: Some Lessons and An Overview", in Burdekin, R.C.K., and P.L. Siklos, Eds., Deflation: Current and Historical Perspectives (Cambridge: Cambridge University Press), pp. 1-27.

Burdekin, R. and Siklos, P. (1999), 'Exchange Rate Regimes and Shifts in Inflation Persistence: Does Nothing Else Matter?', Journal of Money, Credit and Banking, Vol. 31, May, pp. 234-247.

Brunner, K. (1983), "The Pragmatic and Intellectual Tradition of Monetary Policymaking." In Lessons of Monetary Experiences from the 1970s (Karl Brunner, ed.).

Burns, A. (1979), The Anguish of Central Banking, Per Jacobsson Lecture, September.

Cargill, T. (2013), "A Critical Assessment of Measures of Central Bank Independence", Economic Inquiry 51 (January): 260-72.

Chung, H., J-P. Laforte, D. Reifschneider, and J. Williams (2012), "Have We Underestimated the Likelihood and Severity of Zero Lower Bound Events?", Journal of Money, Credit and Banking 44 (February): 47-82.

Cross, P., and P. Bergevin (2012), "Turning Points in Business Cycles in Canada Since 1926 ", C.D. Howe Commentary No. 366, October.

Crow, J. (2002), Making Money (Toronto: John Wiley \& Sons). 
Cukierman, A. (1986), "Central Bank Behavior and Credibility: Some Recent Theoretical Developments", Review of the Federal Reserve Bank of St. Louis (May): 517.

Cukierman, A. (1992), Central Bank Strategy, Credibility and Independence: Theory and Evidence (Cambridge, Mass.: MIT Press).

De Long, B. (1997), “America's Peacetime Inflation: the 1970s", in Reducing Inflation: Motivation and Strategy, Edited by C.D. Romer and D.H. Romer (Chicago: University of Chicago Press),

Dehay, E., and N. Levy (2000), "L'independenance des banques centrales pendant l'entre-deux guerres et ses effects sur l'inflation et la croissance", working paper, Universite de Paris X-Nanterre.

Dincer, N. and B. Eichengreen (2007), "Central Bank Transparency: Where, Why, and With What Effects?", NBER working paper 13003, March, http://www.nber.org/papers/w13003

Dreher, A., J.E. Sturm, and J. de Haan (2998), "Does High Inflation Cause Central Bankers to Lose Their Job? Evidence Based on a New Data Set", European Journal of Political Economy 24 (December): 778-87.

Dupasquier, C., A. Guay, and P. St-Amant (1999), "A Survey of Alternative Methodologies for Estimating Potential Output and the Ouput Gap", Journal of Macroeconomics 21 (Summer): 577-595.

Eijffinger, S., and J. De Haan (1996), The Political-Economy of Central Bank Independence", Special Papers in International Economics, Prineton University, no. 19, May.

Eggertsson, G., and M. Woodford (2003), "The Zero Bound on Interest Rates and Optimal Monetary Policy", Brookings Papers on Economic Activity 34: 139-211.

Eichengreen, B. (1997), " The Gold Standard Since Alec Ford" in Barry Eichengreen and Marc Flandreau (eds) The Gold Standard in Theory and Practice. Second Edition. London: Routledge.

Fellner, William (1976), Towards a Reconstruction of Macroeconomics : Problems of Theory and Policy (Washington, D.C.: American Enterprise Institute).

Ferguson, N., and M. Schularik (2008), "The 'Thin Film of Gold': Monetary Policy Rules and Policy Credibility in Developing Countries”, NBER working paper 13918, April. 
Fortin, P. (1996), "The Great Canadian Slump", Canadian Journal of Economics 29 (November): 761-787.

Freedman, C. and T. Macklem (1998), "A Comment on the 'The Great Canadian Slump”", Canadian Journal of Economics 31 (August): 646-65.

Friedman, M. (1968),"The Role of Monetary Policy", American Economic Review 58 (March): 1-17.

Goodfriend, M. (1986), "Monetary Mystique: Secrecy and Central Banking”, Journal of Monetary Economics 17 (January): 63-92.

Goodfriend, M., and R. King (2013), "The Great Inflation Drift", in M.D. Bordo and A. Orhanides (Eds), The Great Inflation: The Modern Rebirth of Central Banking (Chicago: University of Chicago Press).

Goodhart, C.A.E. (1999), "Central Bankers and Uncertainty", Bank of England Quarterly Bulletin (February): 102-121.

Greenspan, A. (1996), "Opening Remarks", in Achieving Price Stability, A Symposium sponsored by the Federal Reserve Bank of Kansas City, August.

Haberler, Gottfried (1980), "Notes on Rational and Irrational Expectations", reprint 111, American Enterprise Institute (March).

Haltmaier, J. (2012), “Do Recessions Affect Potential Output?” Board of Governors of the Federal Reserve System, International Finance Discussion Papers, No. 1066, December.

Kahn, G. (2012), "Estimated Rules for Monetary Policy", Economic Review, Federal Reserve Bank of Kansas City, Fall5-29.

Killian, L. (2009), "Oil Price Shocks, Monetary Policy and Staglflation", in Inflation in an Era of Relative Price Shocks, edited by R. Fry, C. Jones and C. Kent (Sydney: Reserve Bank fo New Zealand), pp. 60-84.

Kozicki, S., and P.A. Tinsley (2009), "Perhaps the 1970s FOMC Did What it Said it Did", Journal of Monetary Economics 56: 842-855.

La Porta, R., F. Lopez-de-Silanes, and A. Schleifer (2008), "The Economic Consequences of Legal Origins", Journal of Economic Literature 46 (2): 285-332.

Levin, A., and J. Taylor (2013), "Falling Behind the Curve: A Positive Anlysis of StopStart Monetary Policies and the Great Inflation", in M.D. Bordo and A. Orphanides 
(Eds.), The Great Inflation: The Modern Rebirth of Central Banking (Chicago: University of Chicago Press).

Mankiw, N. Gregory, and Jeffrey Miron (1991), "Should the Fed Smooth Interest Rates? The Case of Seasonal Monetary Policy", Carnegie-Rochester Series on Public Policy 34 (Spring): 41-69.

Mauro, P., R. Romeu, A. Binder, and A. Zaman (2013), “A Modern History of Fiscal Prudence and Profligacy", IMF working paper 13/05, January.

Meltzer, Allan (2001), A History of the Federal Reserve, Volume 1: 1913-1951 (Chicago: University of Chicago Press).

Mishkin, F. (2007), "Estimating Potential Output", speech given at the Conference on Price Measurement for Monetary Policy, Federal Reserve Bank of Dallas, Dallas, Texas, available from http://www.c.federalreserve.gov/newsevents/speech/mishkin20070524a.htm.

Mishkin, F. (2005), “The Inflation Targeting Debate”, John Kusczcak Memorial Lecture, Bank of Canada, May.

Orphanides, A. (2003), "The Quest for Prosperity without Inflation." Journal of Monetary Economics, 50(3), 633-663.

Orphanides, A. and S. van Norden (2002), "The Unreliability of Output Gap Estimates in Real-Time", Review of Economics and Statistics 84 (November): 569-583.

Orphanides, A. and J. Williams (2011), "Monetary Policy Mistakes and the Evolution of Inflation Expectations", working paper, June.

Parkin, M. (2012), “Central Bank Laws and Monetary Policy Outcomes: A Three Decade Perspective", available from http://ideas.repec.org/p/uwo/epuwoc/20131.html.

Perron, P. (1989), "The Great Crash, the Oil Price Shock, and the Unit Root Hypothesis", Econometrica 57 (November): 1361-1401.

Pesaran, H., T. Schurmann, and S.M. Weiner (2004), "Modelling Regional Interdependencies Using a Global Error-Correcting Macroeconometric Model", Journal of Business and Economic Statistics 22: 129-162.

Powell, J. (2009), The Bank of Canada of James Elliot Coyne (Montreal and Kingston: McGill-Queen's University Press).

Reinhart, C., and K. Rogoff (2013), "Shifting Mandates: The Federal Reserve's First Centennial", American Economic Review Papers and Proceedings 103 (May): 48-54. 
Romer, C. (2013), "Comments", in M.D. Bordo and A. Orphanides (Eds), The Great Inflation: The Modern Rebirth of Central Banking (Chicago: University of Chicago Press).

Rudebusch, G. (2006), “Monetary Policy Inertia: Fact or Fiction?” International Journal of Central Banking, December, pp. 85-135.

Rudebusch, G. (2002), "Term Structure Evidence on Interest Rate Smoothing and Monetary Policy Inertia", Journal of Monetary Economics 49 (September): 1161-1187.

Sack, B., and V. Wieland (2000), "Interest-Rate Smoothing and Optimal Monetary Policy: A Review of Recent Empirical Evidence", Journal of Economics and Business 52 (January-April): 205-228.

Siklos, P.L. (2002), The Changing Face of Central Banking (Cambridge: Cambridge University Press).

Siklos, P.L. (2003), "Assessing the Impact of Changes in Transparency and Accountability at the Bank of Canada", Canadian Public Policy 29 (September): 279299.

Siklos, P.L. (2008), “No Single Definition of Central Bank Independence is Right for All Countries", European Journal of Political Economy 24: 802-816.

Siklos, P.L. (2010), "Revisiting the Coyne Affair: A Singular Event that Changed the Course of Canadian Monetary History", Canadian Journal of Economics 43 (3): 9941015.

Siklos, P.L. (2014), "Communications Challenges for Multi-Tasking Central Banks: Evidence and Implications", International Finance 17 (Spring): 77-98.

Silber, W.L. (2012), Volcker (New York: Bloomsbury Press).

Stock, J.H.. and M.W. Watson (2007), "Why Has US Inflation Become Harder to Forecast?", Journal of Money, Credit and Banking (February).

Stock, J., and M. Yogo (2005), "Testing for Weak Instruments in Linear IV Regressions", in Identification and Inference for Econometric Models: Essays in Honor of Thomas Rothenberg, D.W.K. Andrews and J.H. Stock, Eds. (Cambridge: Cambridge University Press).

Taylor, J. (1998), “A Historical Analysis of Monetary Policy Rules”, in J. Taylor (Ed.), Monetary Policy Rules (Chicago: University of Chicago Press), pp. 314-341.

Taylor, J. (1993), "Discretion versus Policy Rules in Practice," Carnegie-Rochester Conference Series on Public Policy, vol. 39, December, pp. 195-214. 
Waller, C. (2011), "Independence and Accountability: Why the Fed is a Well-Designed Central Bank", Review of the Federal Reserve Bank of St. Louis (Sept/Oct): 293-301.

Woodford, M. (2003), Interest and Prices: Foundations of a Theory of Monetary Policy, Princeton: Princeton University Press. 
Table 1 The Origins of Ten Central Banks

\begin{tabular}{|c|c|c|c|}
\hline Year & Country & Name & Motivation \\
\hline 1668 & Sweden & $\begin{array}{l}\text { Bank of the Estates of } \\
\text { the Realm. Forerunner } \\
\text { of the Riksbank }\end{array}$ & Finance war \\
\hline 1694 & UK & Bank of England & Finance war \\
\hline 1800 & France & Banque de France & $\begin{array}{l}\text { Manage public debt, generate } \\
\text { seignorage }\end{array}$ \\
\hline 1816 & Norway & Bank of Norway & $\begin{array}{l}\text { Economic crisis in Denmark } \\
\text { prompts monetary reform }\end{array}$ \\
\hline 1876 & Germany & $\begin{array}{l}\text { Reichsbank. Forerunner } \\
\text { of Bundesbank }\end{array}$ & $\begin{array}{l}\text { Consolidation of previous } \\
\text { note issuing authorities } \\
\text { following unification }\end{array}$ \\
\hline 1882 & Japan & Bank of Japan & $\begin{array}{l}\text { Part of modernization of Meiji } \\
\text { regime }\end{array}$ \\
\hline 1893 & Italy & Banca d'Italia & $\begin{array}{l}\text { Consolidation of previous } \\
\text { note issuing authorities } \\
\text { following unification }\end{array}$ \\
\hline 1907 & Switzerland & Swiss National Bank & $\begin{array}{l}\text { Elimination of note issuing } \\
\text { competition }\end{array}$ \\
\hline 1913 & USA & Federal Reserve System & $\begin{array}{l}\text { Creation of lender of last } \\
\text { resort and other banking } \\
\text { related functions }\end{array}$ \\
\hline 1934 & Canada & Bank of Canada & Lender of last resort \\
\hline
\end{tabular}

Sources: Siklos (2002) and updated from individual central bank websites accessible through the BIS's Central bank hub, http://www.bis.org/cbanks.htm. 


\section{Table 2 Panel Regression Estimates of the Determinants of Credibility}

A. Interest Rate Instrument

\begin{tabular}{|c|c|c|c|c|c|c|c|c|c|c|c|c|c|c|c|c|}
\hline & \multicolumn{2}{|c|}{$1871-2008$} & \multicolumn{2}{|c|}{$1950-2008$} & \multicolumn{2}{|c|}{$1871-2008 \mathrm{~T}$} & \multicolumn{2}{|c|}{$1950-2008 \mathrm{~T}$} & \multicolumn{2}{|c|}{$\begin{array}{c}1871-2008 \\
\text { +ve }\end{array}$} & \multicolumn{2}{|c|}{$\begin{array}{c}\text { 1871-2008 - } \\
\text { ve }\end{array}$} & \multicolumn{2}{|c|}{$\begin{array}{c}\text { 1950-2008 } \\
\text { +ve }\end{array}$} & \multicolumn{2}{|c|}{$\begin{array}{c}1950-2008- \\
\text { ve }\end{array}$} \\
\hline $\begin{array}{l}\text { Ind. } \\
\text { Variables }\end{array}$ & Coeff. & s.e. & Coeff. & s.e. & Coeff. & s.e. & Coeff. & s.e. & Coeff. & s.e. & Coeff. & s.e. & Coeff. & s.e. & Coeff. & s.e. \\
\hline Gold Standard & $-57.57+$ & 28.04 & NA & NA & $-5.14 \ddagger$ & 5.69 & NA & NA & $-3.67+$ & 1.55 & $-2.40 \ddagger$ & 1.49 & NA & $\mathrm{NA}$ & NA & $\mathrm{NA}$ \\
\hline $\begin{array}{l}\text { Money } \\
\text { growth }\end{array}$ & 2.71 & 2.73 & 5.47 & 6.27 & $0.57 \ddagger$ & 0.32 & 0.18 & 0.22 & $0.20^{*}$ & 0.06 & $0.18^{*}$ & 0.06 & 0.07 & 0.06 & -0.04 & 0.05 \\
\hline $\begin{array}{c}\text { Loans to GDP } \\
\text { ratio } \\
\end{array}$ & -1.16 & 1.74 & -0.58 & 1.32 & -0.19 & 0.27 & -0.36 & 0.23 & 0.02 & 0.02 & $0.06^{*}$ & 0.02 & $0.06^{*}$ & 0.02 & $0.08^{*}$ & 0.02 \\
\hline $\begin{array}{c}\text { Debt to GDP } \\
\text { ratio }\end{array}$ & -0.52 & 0.71 & 0.56 & 0.79 & -0.00 & 0.08 & -0.05 & 0.12 & -0.02 & 0.02 & -0.02 & 0.01 & $-0.07 *$ & 0.01 & $-0.07 *$ & 0.02 \\
\hline Equity returns & 0.60 & 0.56 & 0.79 & 0.69 & -0.07 & 0.07 & -0.09 & 0.08 & -0.01 & 0.01 & -0.01 & 0.01 & -0.01 & 0.01 & -0.00 & 0.01 \\
\hline $\begin{array}{l}\text { Oil price } \\
\text { shocks }\end{array}$ & 35.27 & 71.30 & -3.99 & 9.20 & 0.33 & 5.23 & -0.00 & 0.76 & $2.22+$ & 0.94 & 0.96 & 1.29 & $4.68^{*}$ & 0.97 & $3.58^{+}$ & 1.61 \\
\hline $\begin{array}{c}\text { Financial } \\
\text { Crises } \\
\end{array}$ & $30.31+$ & 16.69 & $52.13 \ddagger$ & 32.05 & 0.40 & 1.33 & 1.17 & 1.57 & $0.55 \ddagger$ & 0.31 & 0.29 & 0.32 & 0.44 & 0.46 & 0.10 & 0.34 \\
\hline $\begin{array}{c}\text { Central Bank } \\
\text { Independence }\end{array}$ & NA & NA & -18.75 & 14.03 & NA & NA & $-1.01+$ & $0.52+$ & NA & NA & NA & NA & -2.71 & 1.98 & $-1.29 *$ & 1.93 \\
\hline $\begin{array}{c}\text { Exchange rate } \\
\text { regime }\end{array}$ & NA & NA & $11.79+$ & 5.50 & NA & NA & 1.47 & 0.69 & NA & $\mathrm{NA}$ & NA & NA & -0.33 & $0.08^{*}$ & -0.39 & 0.12 \\
\hline $\begin{array}{l}\text { Summary } \\
\text { Statistics }\end{array}$ & & & & & & & & & & & & & & & & \\
\hline Adjusted R² & 0.10 & & 0.11 & & 0.11 & & 0.48 & & 0.43 & & 0.44 & & 0.49 & & 0.46 & \\
\hline F-statistic & 4.54 & & 3.46 & & 3.46 & & 14.28 & & 36.69 & & 39.39 & & 30.06 & & 25.37 & \\
\hline $\mathrm{p}$-value & 0.00 & & 0.00 & & 0.00 & & 0.00 & & 0.00 & & 0.00 & & 0.00 & & 0.00 & \\
\hline
\end{tabular}


B. Money Supply Growth Instrument

\begin{tabular}{|c|c|c|c|c|c|c|c|c|c|c|c|c|c|c|c|c|}
\hline & \multicolumn{2}{|c|}{ 1871-2008 } & \multicolumn{2}{|c|}{$1950-2008$} & \multicolumn{2}{|c|}{$1871-2008 \mathrm{~T}$} & \multicolumn{2}{|c|}{$1950-2008 \mathrm{~T}$} & \multicolumn{2}{|c|}{$\begin{array}{c}\text { 1871-2008 } \\
\text { +ve }\end{array}$} & \multicolumn{2}{|c|}{$\begin{array}{c}1871-2008- \\
\text { ve }\end{array}$} & \multicolumn{2}{|c|}{$\begin{array}{c}1950-2008 \\
\text { +ve }\end{array}$} & \multicolumn{2}{|c|}{$\begin{array}{c}1950-2008- \\
\text { ve }\end{array}$} \\
\hline $\begin{array}{l}\text { Ind. } \\
\text { Variables }\end{array}$ & Coeff. & s.e. & Coeff. & s.e. & Coeff. & s.e. & Coeff. & s.e. & Coeff. & s.e. & Coeff. & s.e. & Coeff. & s.e. & Coeff. & s.e. \\
\hline Gold Standard & 8.97 & 37.76 & NA & NA & -2.75 & 2.88 & NA & NA & $-3.76^{*}$ & 1.22 & $-4.08^{*}$ & 1.36 & NA & NA & $\mathrm{NA}$ & NA \\
\hline $\begin{array}{l}\text { Money } \\
\text { growth }\end{array}$ & $7.43 \ddagger$ & 4.24 & 7.95 & 8.99 & 0.08 & 0.14 & 0.09 & 0.16 & $0.35^{*}$ & 0.09 & $0.31 *$ & 0.09 & $0.08 \ddagger$ & 0.05 & $0.20 *$ & 0.05 \\
\hline $\begin{array}{c}\text { Loans to GDP } \\
\text { ratio } \\
\end{array}$ & 24.82 & 16.81 & 6.33 & 14.62 & -1.24 & 1.34 & -1.28 & 1.20 & -0.64 & 0.23 & $-0.69 *$ & 0.24 & $-0.51^{*}$ & 0.14 & $-0.52^{*}$ & 0.14 \\
\hline $\begin{array}{c}\text { Debt to GDP } \\
\text { ratio }\end{array}$ & -0.34 & 1.00 & -6.31 & 11.89 & 0.09 & 0.09 & 0.08 & 0.12 & -0.02 & 0.01 & $-0.02+$ & 0.01 & -0.02 & 0.03 & 0.02 & 0.02 \\
\hline Equity returns & -0.67 & 0.83 & -1.08 & 1.48 & -0.03 & 0.02 & $-0.04+$ & 0.02 & 0.01 & 0.01 & 0.01 & 0.01 & 0.00 & 0.00 & 0.00 & 0.00 \\
\hline $\begin{array}{l}\text { Oil price } \\
\text { shocks }\end{array}$ & 46.56 & 56.83 & 53.59 & 36.17 & 4.66 & 2.93 & 0.40 & 0.50 & 0.94 & 0.97 & $2.13^{+}$ & 1.09 & 0.07 & 1.95 & 0.30 & 1.94 \\
\hline $\begin{array}{c}\text { Financial } \\
\text { Crises }\end{array}$ & 46.08 & 29.18 & 126.46 & 135.55 & 0.69 & 0.86 & 1.57 & 1.02 & $1.15^{*}$ & 0.46 & 0.68 & 0.44 & 0.24 & 0.34 & 0.32 & 0.34 \\
\hline $\begin{array}{c}\text { Central Bank } \\
\text { Independence }\end{array}$ & NA & NA & -78.97 & 62.69 & & & 5.99 & 5.00 & $\mathrm{NA}$ & NA & NA & NA & $-9.48 *$ & 3.60 & $-3.03 \ddagger$ & 1.68 \\
\hline $\begin{array}{c}\text { Exchange rate } \\
\text { regime }\end{array}$ & NA & NA & 65.33 & 63.70 & & & 0.03 & 0.51 & NA & NA & $\mathrm{NA}$ & NA & -0.07 & 0.18 & 0.02 & 0.17 \\
\hline $\begin{array}{l}\text { Summary } \\
\text { Statistics }\end{array}$ & & & & & & & & & & & & & & & & \\
\hline Adjusted R ${ }^{2}$ & 0.06 & & 0.06 & & 0.60 & & 0.66 & & 0.39 & & 0.38 & & 0.44 & & 0.44 & \\
\hline F-statistic & 2.98 & & 2.35 & & 29.51 & & 26.68 & & 20.39 & & 21.25 & & 24.32 & & 24.32 & \\
\hline p-value & 0.00 & & 0.00 & & 0.00 & & 0.00 & & 0.00 & & 0.00 & & 0.00 & & 0.00 & \\
\hline
\end{tabular}


C. Exchange Rate Instrument

\begin{tabular}{|c|c|c|c|c|c|c|c|c|c|c|c|c|c|c|c|c|}
\hline & \multicolumn{2}{|c|}{$1871-2008$} & \multicolumn{2}{|c|}{$1950-2008$} & \multicolumn{2}{|c|}{$1871-2008 \mathrm{~T}$} & \multicolumn{2}{|c|}{$1950-2008 \mathrm{~T}$} & \multicolumn{2}{|c|}{$\begin{array}{c}\text { 1871-2008 } \\
\text { +ve }\end{array}$} & \multicolumn{2}{|c|}{$\begin{array}{c}\text { 1871-2008 - } \\
\text { ve }\end{array}$} & \multicolumn{2}{|c|}{$\begin{array}{c}\text { 1950-2008 } \\
\text { +ve }\end{array}$} & \multicolumn{2}{|c|}{$\begin{array}{c}1950-2008- \\
\text { ve }\end{array}$} \\
\hline $\begin{array}{l}\text { Ind. } \\
\text { Variables }\end{array}$ & Coeff. & s.e. & Coeff. & s.e. & Coeff. & s.e. & Coeff. & s.e. & Coeff. & s.e. & Coeff. & s.e. & Coeff. & s.e. & Coeff. & s.e. \\
\hline Gold Standard & -25.23 & 25.72 & NA & NA & $-12.16+$ & 6.26 & NA & NA & $-5.13^{*}$ & 1.77 & $-5.78^{*}$ & 1.06 & NA & NA & NA & NA \\
\hline $\begin{array}{l}\text { Money } \\
\text { growth }\end{array}$ & 2.18 & 1.68 & -1.26 & 1.11 & $0.54+$ & 0.26 & 0.49 & 0.38 & $0.14^{*}$ & 0.04 & $0.11^{*}$ & 0.04 & 0.01 & 0.03 & 0.03 & 0.04 \\
\hline $\begin{array}{c}\text { Loans to GDP } \\
\text { ratio } \\
\end{array}$ & 0.40 & 0.66 & $-1.20 *$ & 0.38 & -0.14 & 0.54 & -0.36 & 0.48 & -0.01 & 0.02 & $0.31^{*}$ & 0.11 & 0.02 & 0.02 & 0.01 & 0.02 \\
\hline $\begin{array}{c}\text { Debt to GDP } \\
\text { ratio } \\
\end{array}$ & -0.25 & 0.32 & $-1.86 *$ & 0.40 & -0.11 & 0.08 & $-0.29+$ & 0.13 & -0.02 & 0.02 & -0.01 & 0.01 & $-0.09 *$ & 0.02 & $-0.08 *$ & 0.02 \\
\hline Equity returns & 0.31 & 0.33 & 0.30 & 0.22 & $-0.11^{*}$ & 0.04 & $-0.15^{*}$ & 0.05 & -0.00 & 0.01 & -0.00 & 0.01 & 0.00 & 0.01 & 0.00 & 0.01 \\
\hline $\begin{array}{l}\text { Oil price } \\
\text { shocks }\end{array}$ & -17.08 & 20.54 & $52.18^{*}$ & 18.25 & $10.53^{+}$ & 4.47 & $21.31 *$ & 7.90 & -0.17 & 1.53 & $-3.95^{*}$ & 1.34 & $3.97 *$ & 0.70 & $6.06^{*}$ & 1.18 \\
\hline $\begin{array}{c}\text { Financial } \\
\text { Crises }\end{array}$ & $29.83 *$ & 11.18 & 7.68 & 10.07 & 1.83 & 1.64 & 2.90 & 2.06 & $0.91^{*}$ & 0.35 & $0.70^{*}$ & 0.26 & 0.41 & 0.33 & $0.55^{+}$ & 0.23 \\
\hline $\begin{array}{c}\text { Central Bank } \\
\text { Independence }\end{array}$ & $\mathrm{NA}$ & NA & $-4.80+$ & 2.35 & & & $-4.59 *$ & 1.55 & NA & NA & NA & NA & $-3.37 *$ & 1.73 & $-3.81 \ddagger$ & 2.05 \\
\hline $\begin{array}{c}\text { Exchange rate } \\
\text { regime }\end{array}$ & NA & $\mathrm{NA}$ & 1.83 & 1.40 & & & 0.13 & 0.81 & NA & NA & NA & $\mathrm{NA}$ & $-0.17 *$ & 0.08 & $-0.33^{*}$ & 0.11 \\
\hline $\begin{array}{l}\text { Summary } \\
\text { Statistics }\end{array}$ & & & & & & & & & & & & & & & & \\
\hline Adjusted R ${ }^{2}$ & 0.09 & & 0.02 & & 0.49 & & 0.53 & & 0.55 & & 0.55 & & 0.71 & & 0.73 & \\
\hline F-statistic & 4.08 & & 1.35 & & 24.95 & & 19.63 & & 58.20 & & 54.83 & & 69.67 & & 70.97 & \\
\hline p-value & 0.00 & & 0.12 & & 0.00 & & 0.00 & & 0.00 & & 0.00 & & 0.00 & & 0.00 & \\
\hline
\end{tabular}




\section{Figure 1 The Anatomy of Inflation in 10 Countries}

CANADA

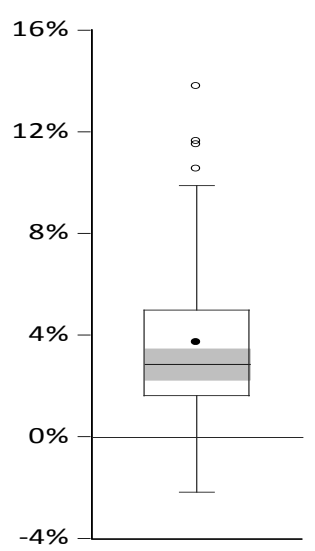

NORWAY

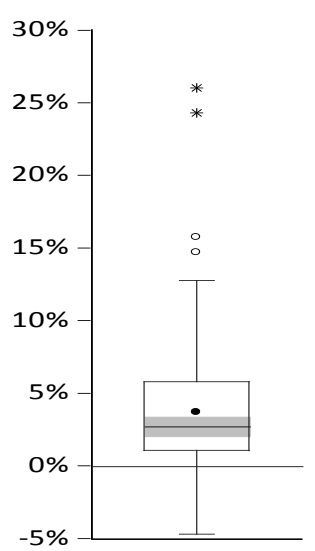

FRANCE

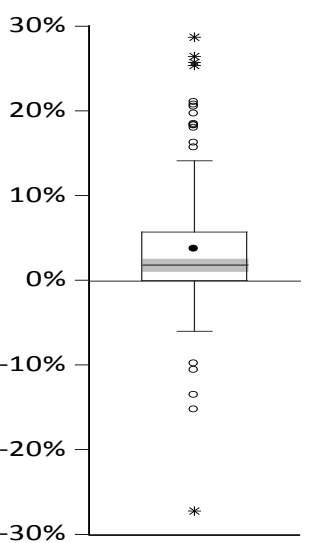

SWEDEN

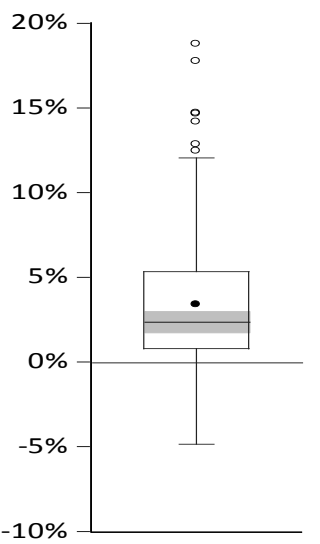

GERMANY

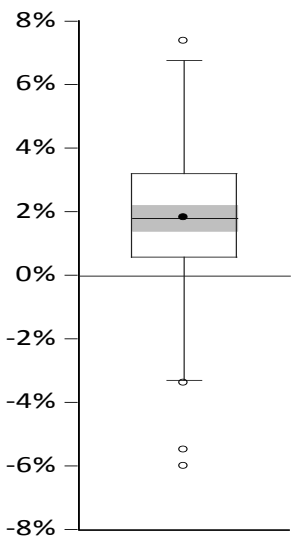

SWITZERLAND

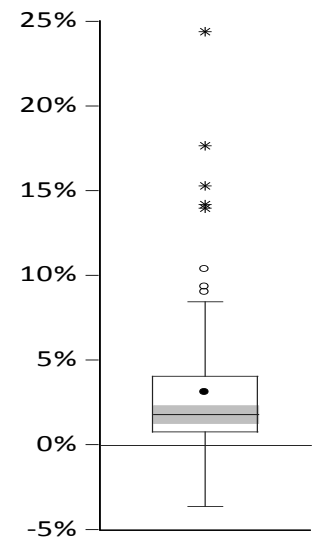

ITALY

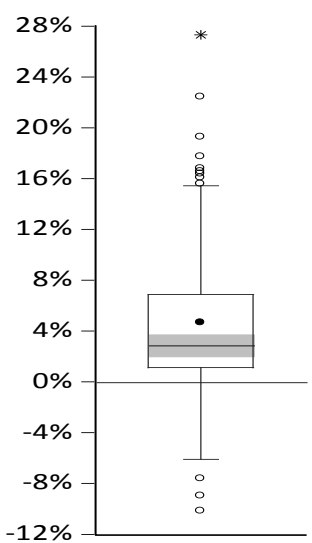

UNITED KINGDOM

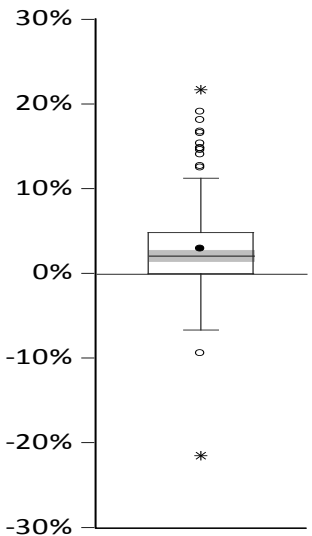

JAPAN

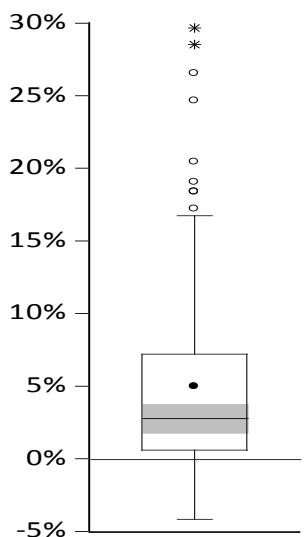

UNITED STATES

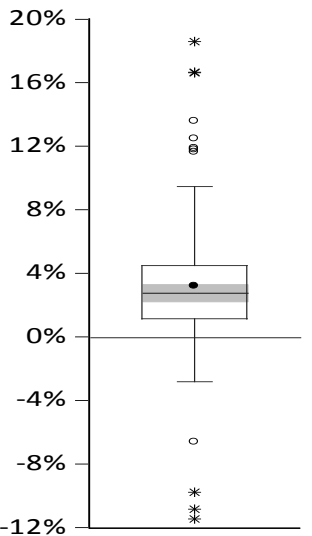




\section{Figure 2 Years of Low Inflation and Deflation}

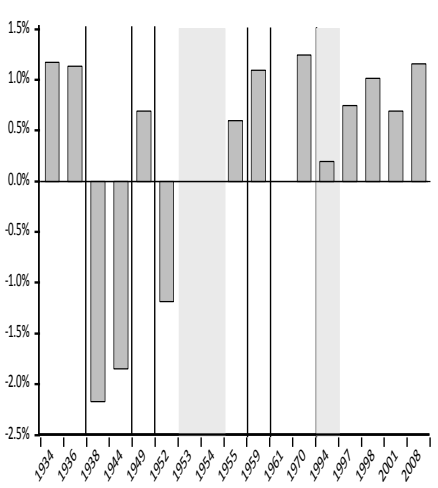

Years of Low Inflation and Délation:Norway

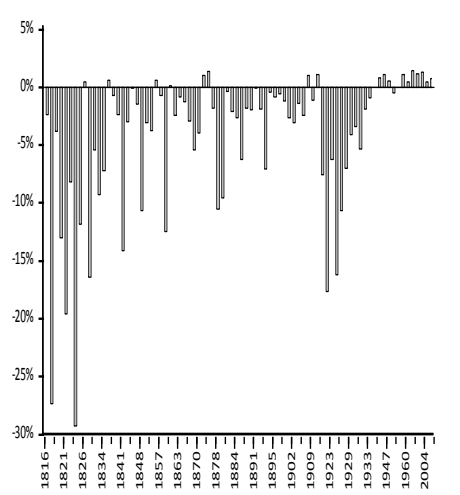

Vearsof L Low Inflation and Deflation:Sweder
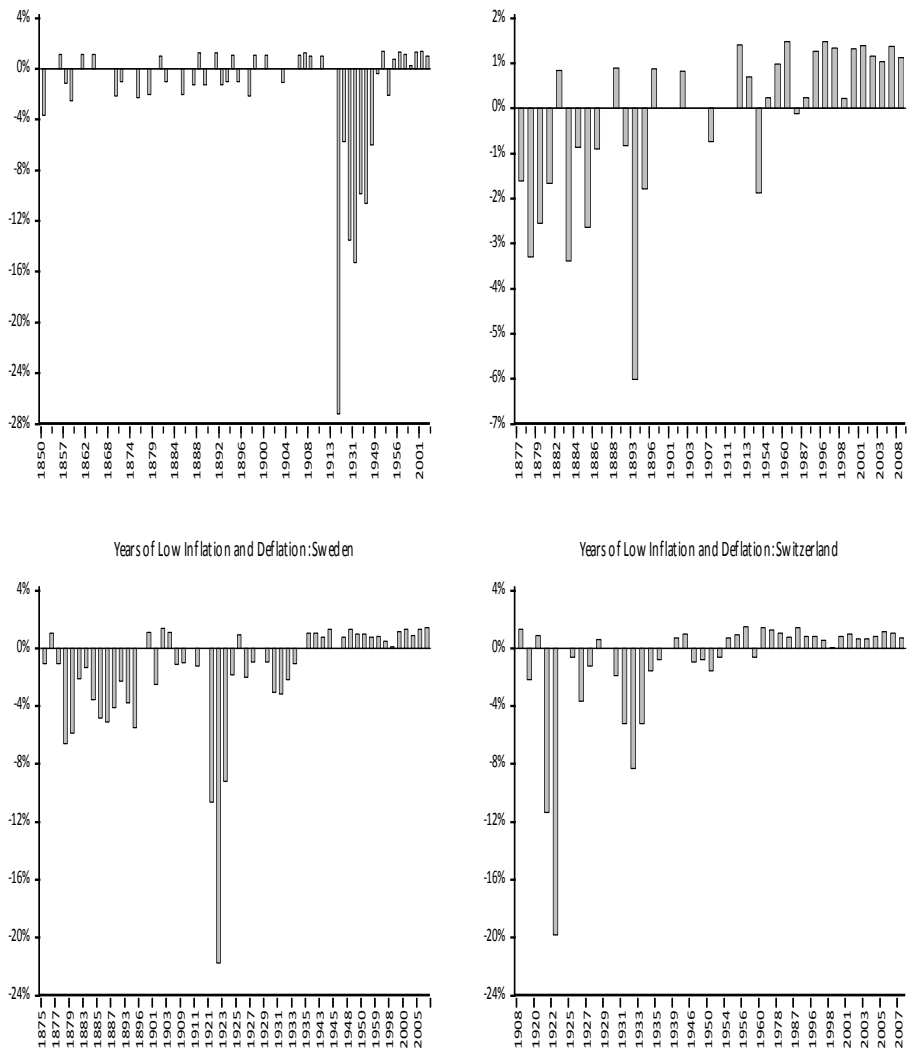

Vears of Low Ifflation and Deflation:Germany

Vears of Low Inffltion and Deflation:taly

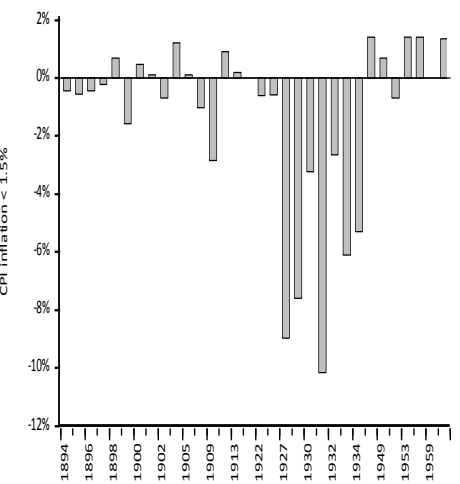

Years of Low Inflation and Delation:United Kinged om

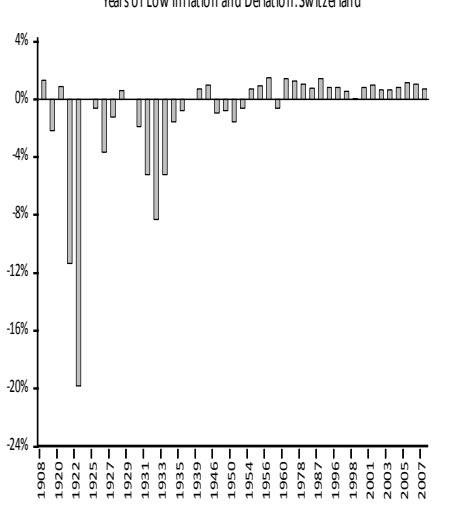

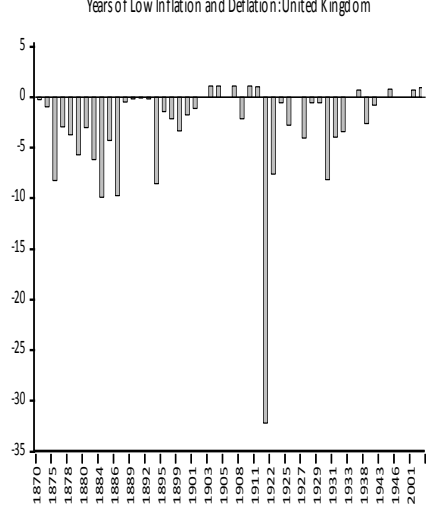

Years of L Low Iffitation and Déltation:J apan

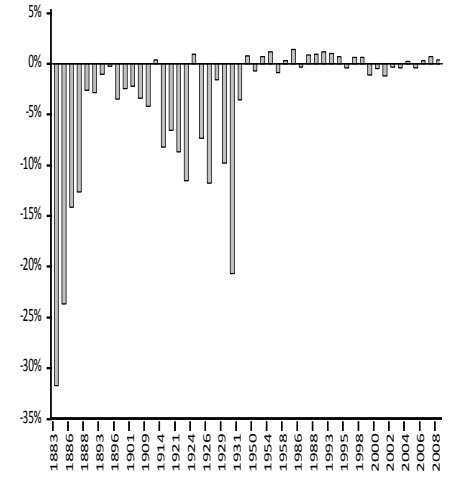

Years of L Lo w inflation and Délation:United States

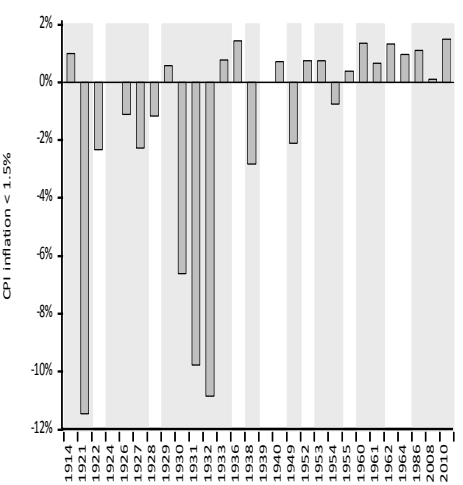


Figure 3 The Persistence of Credibility

A. Interest Rate Instrument

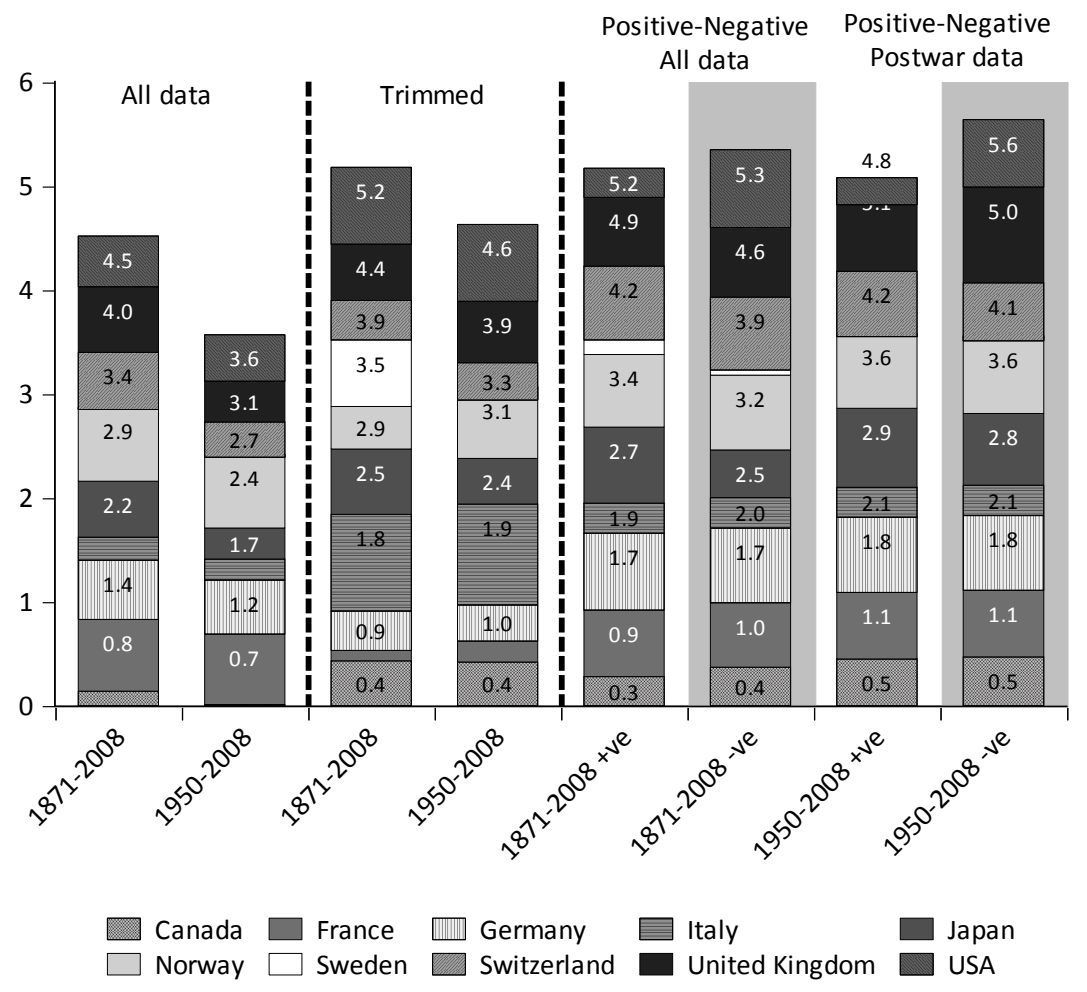




\section{B. Money Growth Instrument}

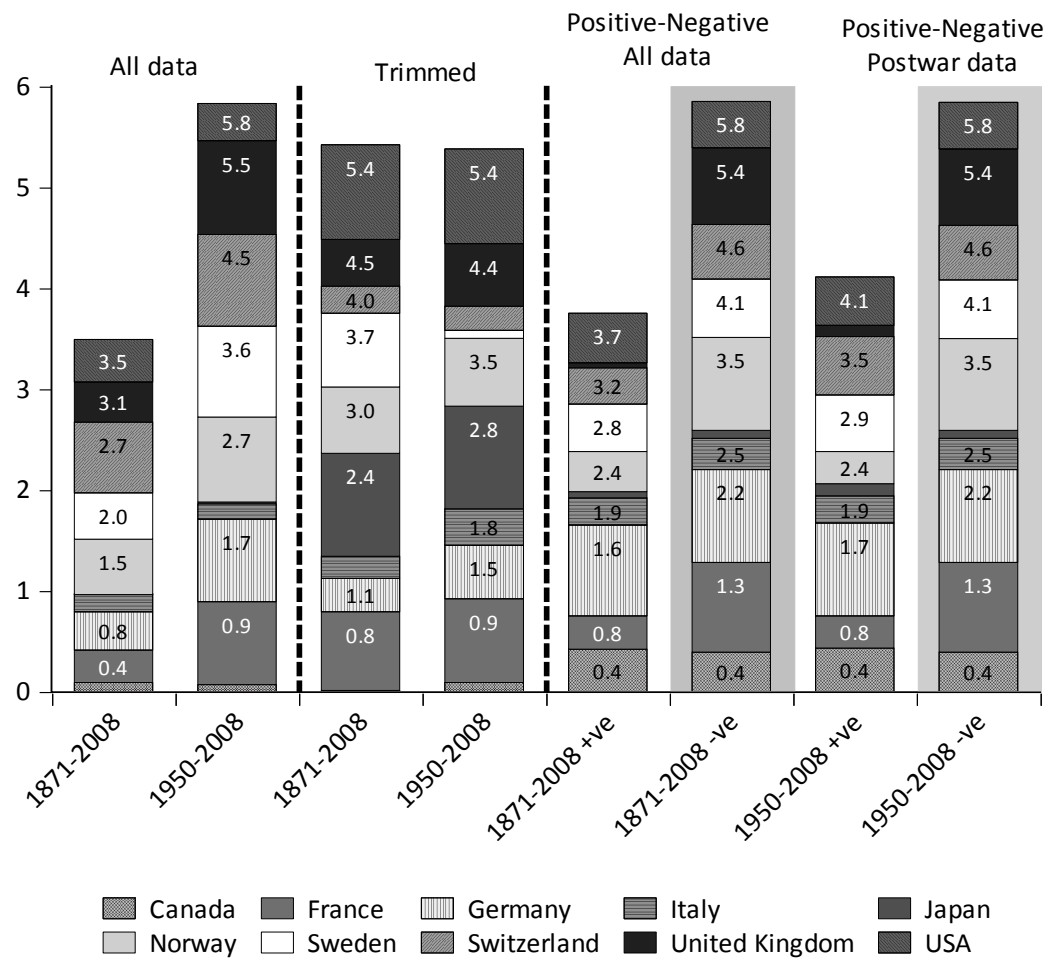

C. Exchange Rate Instrument

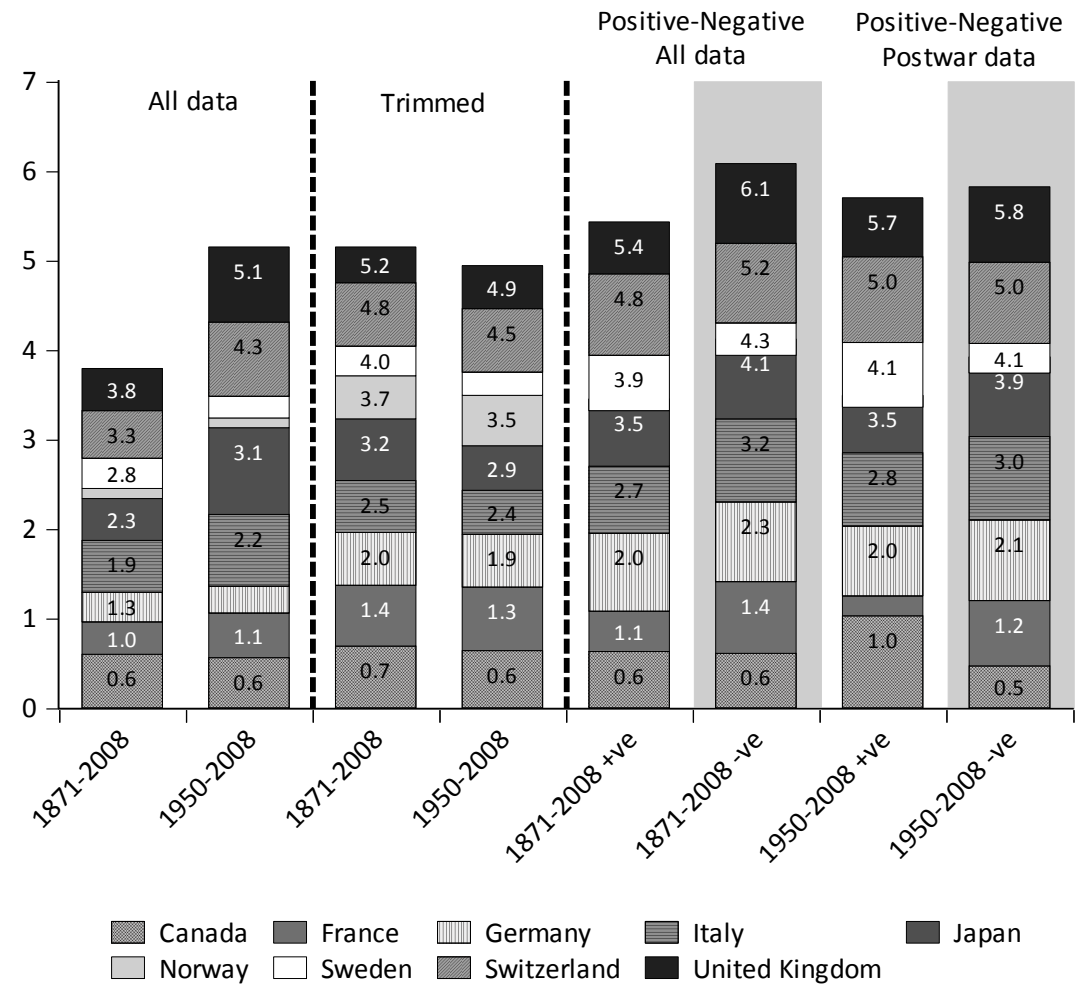


Figure 4 Inflation Shocks and Credibility

Full sample: interest rate instrument

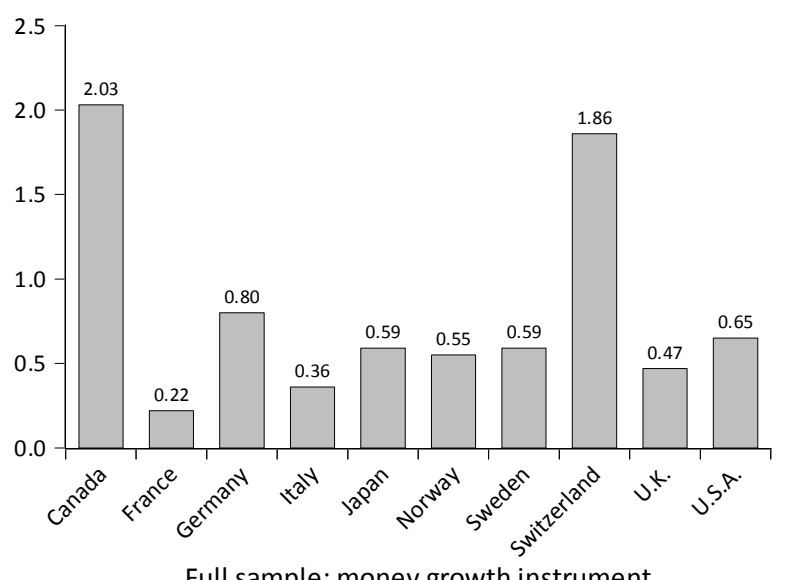

Full sample: money growth instrument
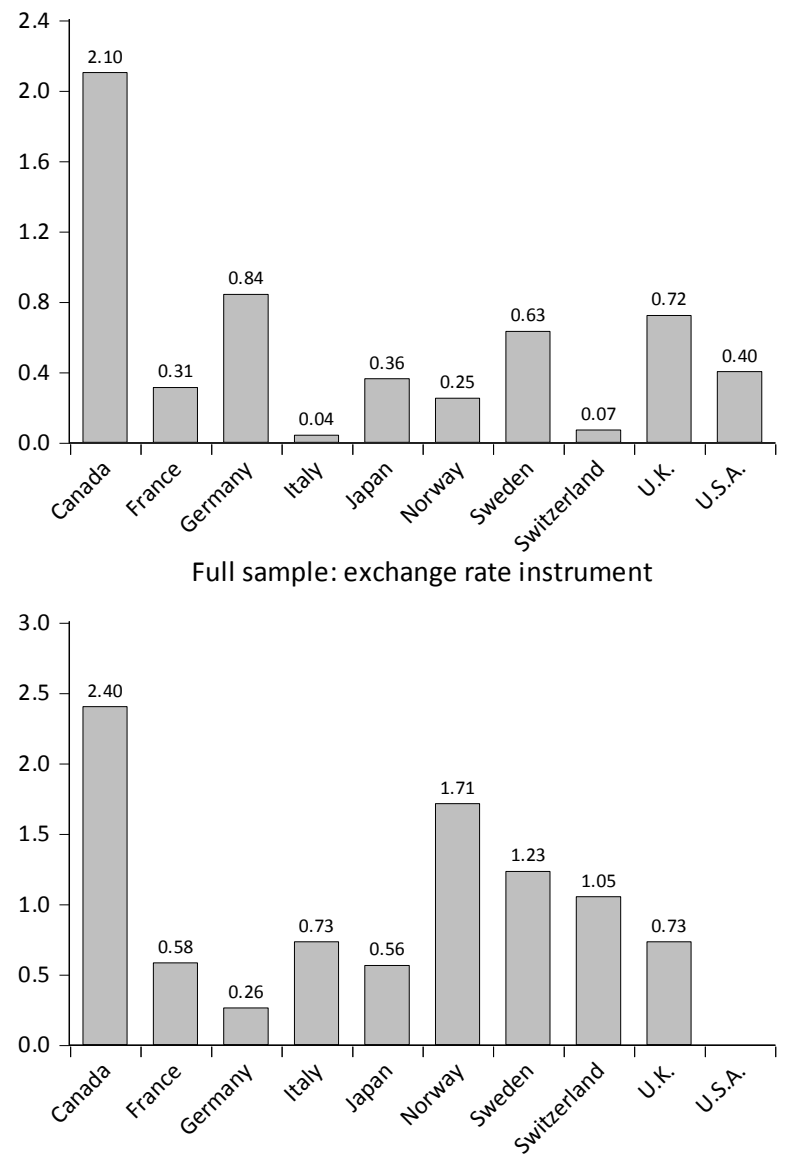

Post WWII: interest rate instrument
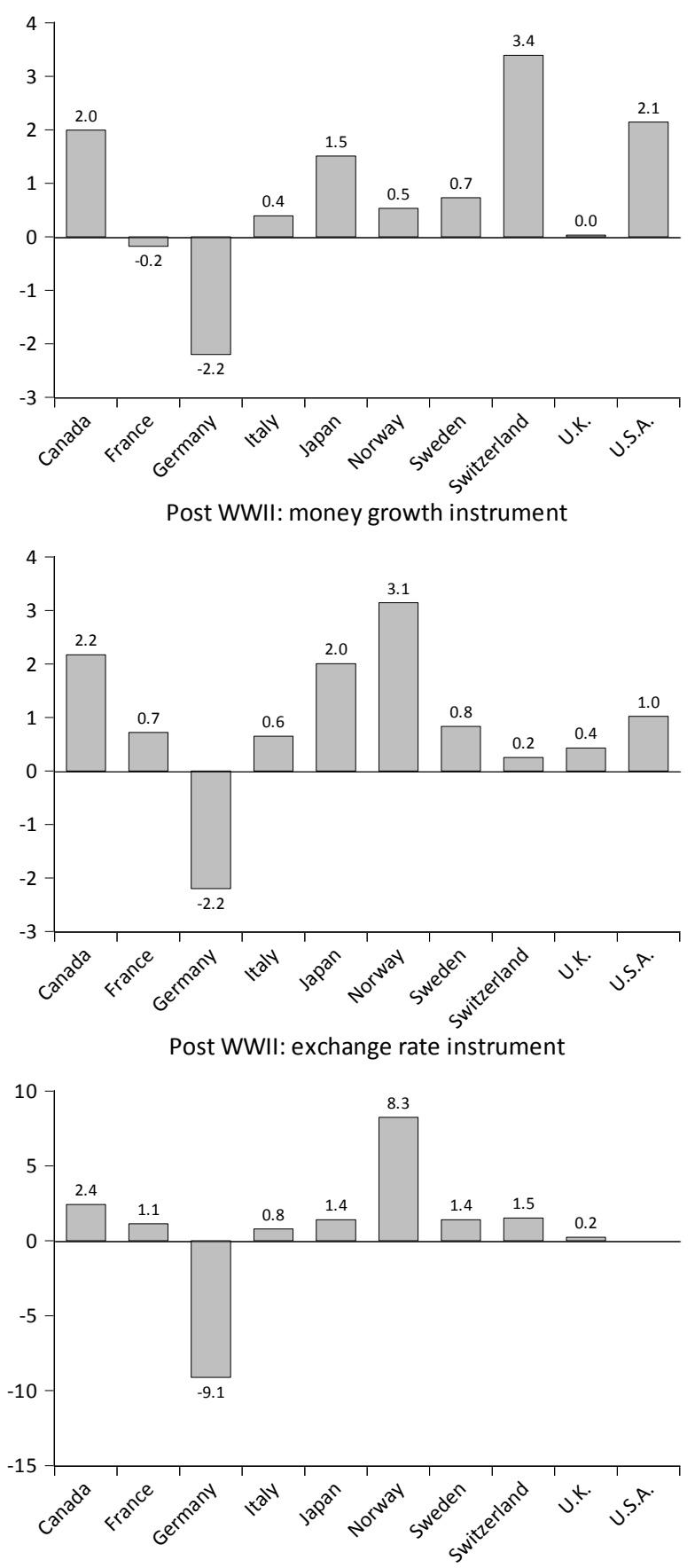
Figure 5A Inflation and Expected Inflation in the U.S. Since the Fed's Creation

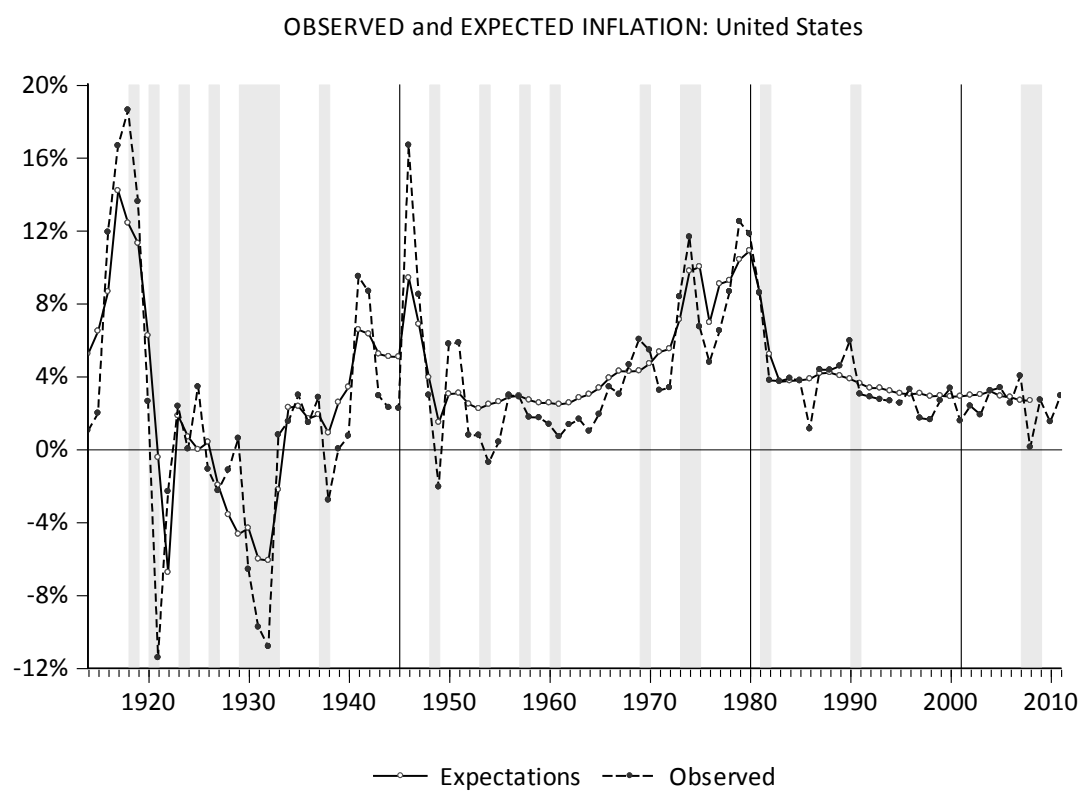

Figure 5B Inflation and Expected Inflation in the U.K. Since 1870

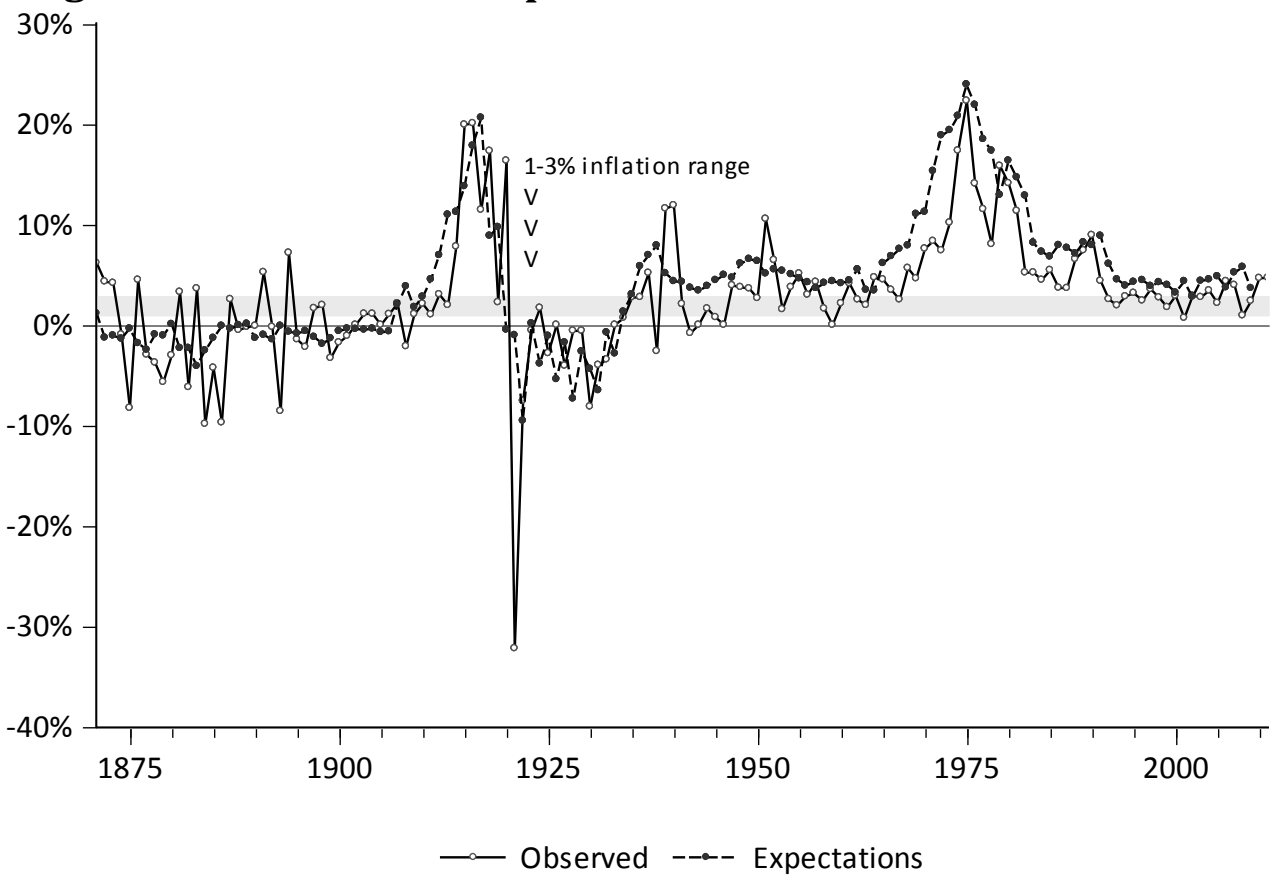


Figure 5C Inflation and Expected Inflation in Germany Since 1871 OBSERVED and EXPECTED INFLATION: Germany

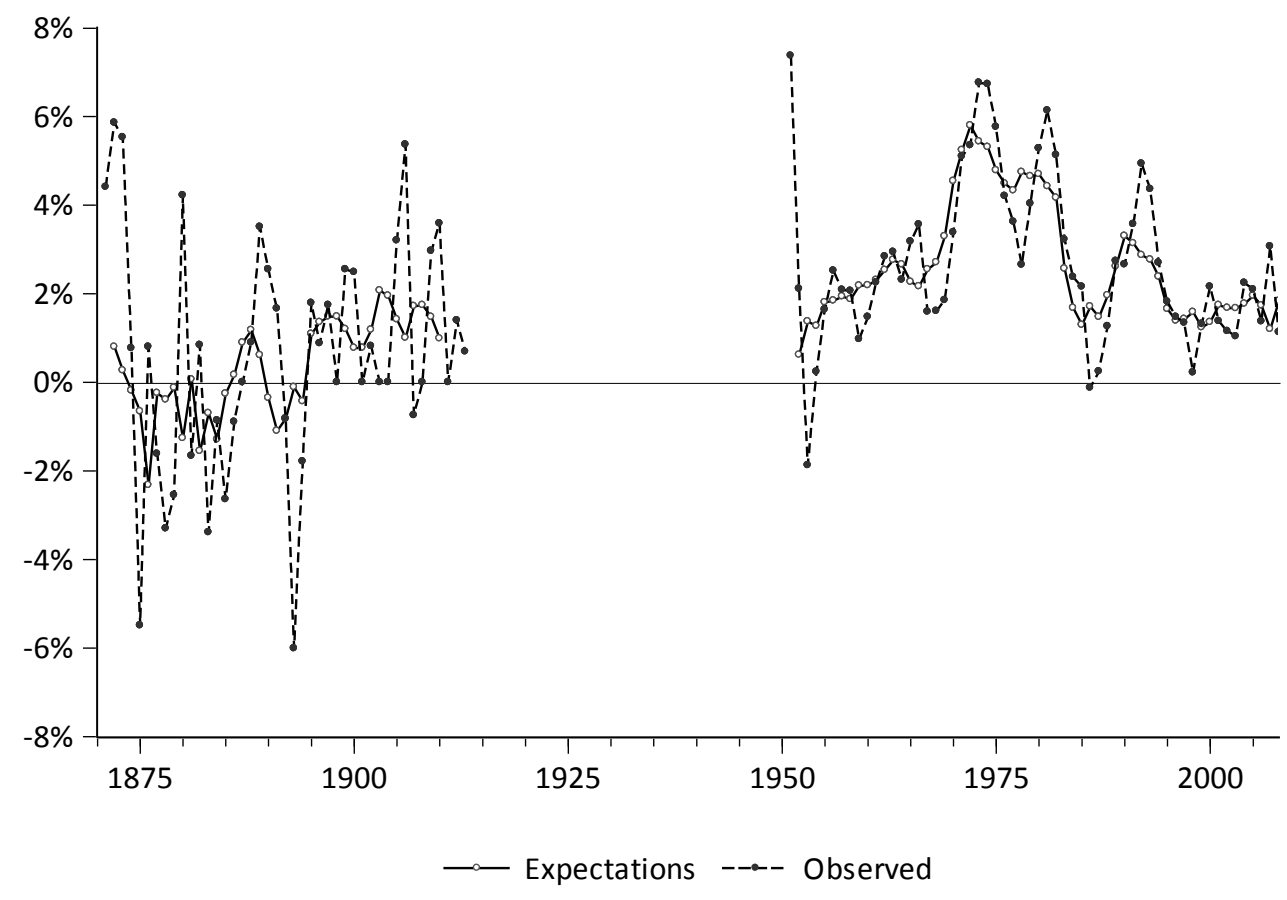


Figure 6A Low and Deflationary Periods in the U.S. Since the Fed's Creation

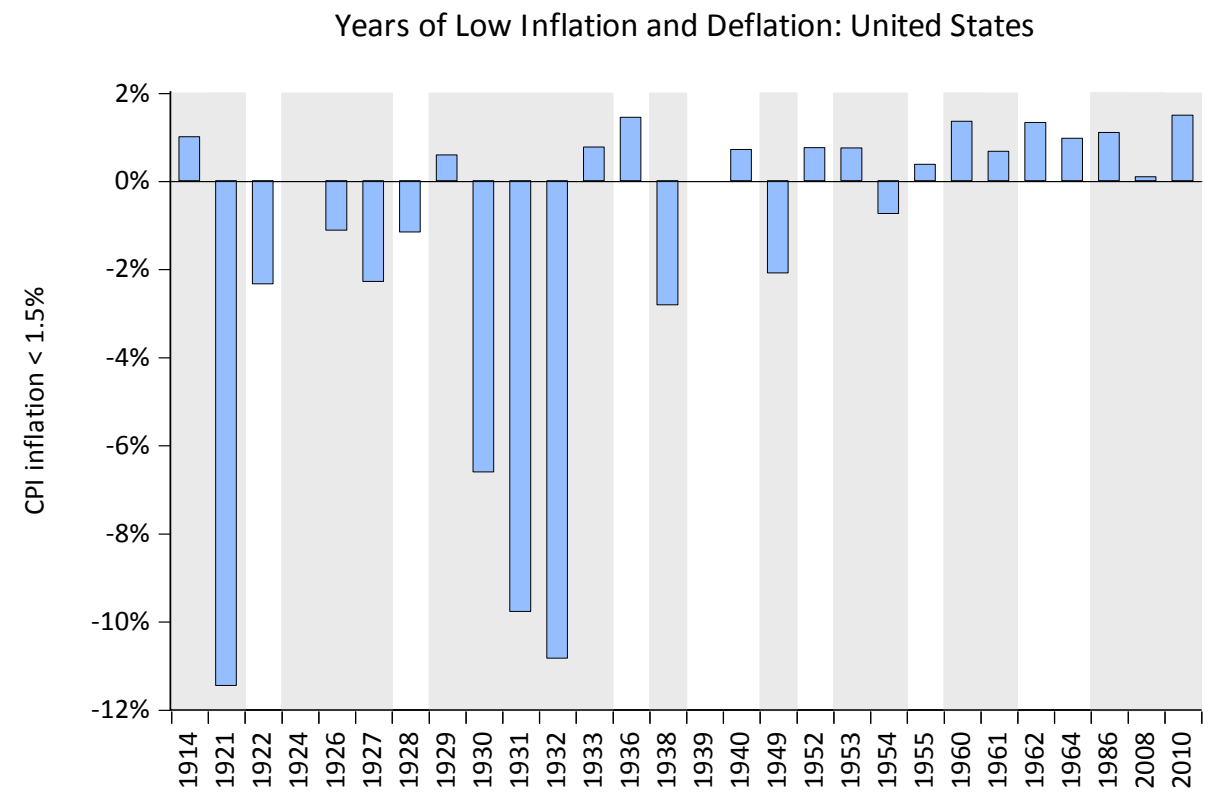

Figure 6B Low and Deflationary Periods in the U.K.

Years of Low Inflation and Deflation: United Kingdom

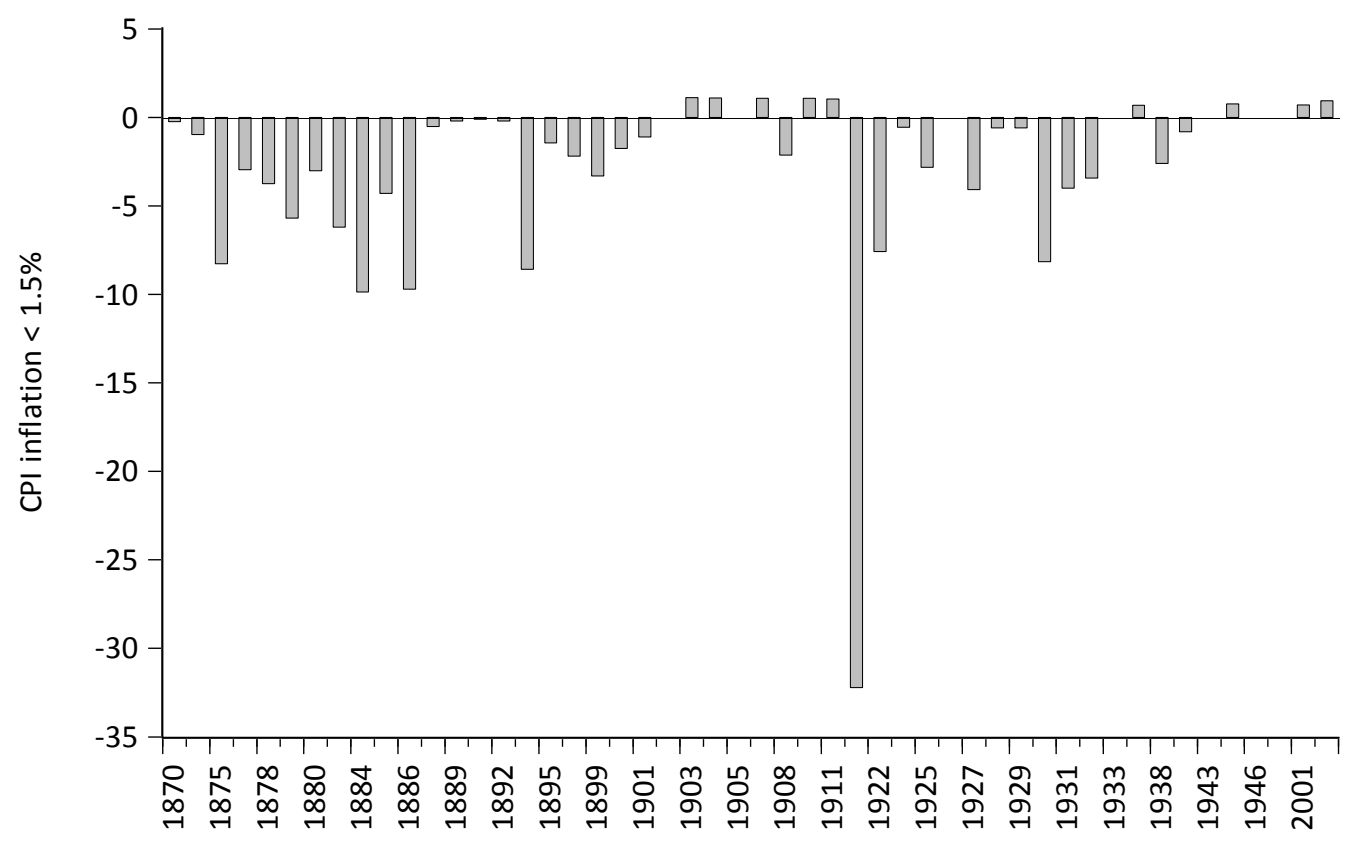


Figure 6C Low and Deflationary Periods in Germany

Years of Low Inflation and Deflation: Germany

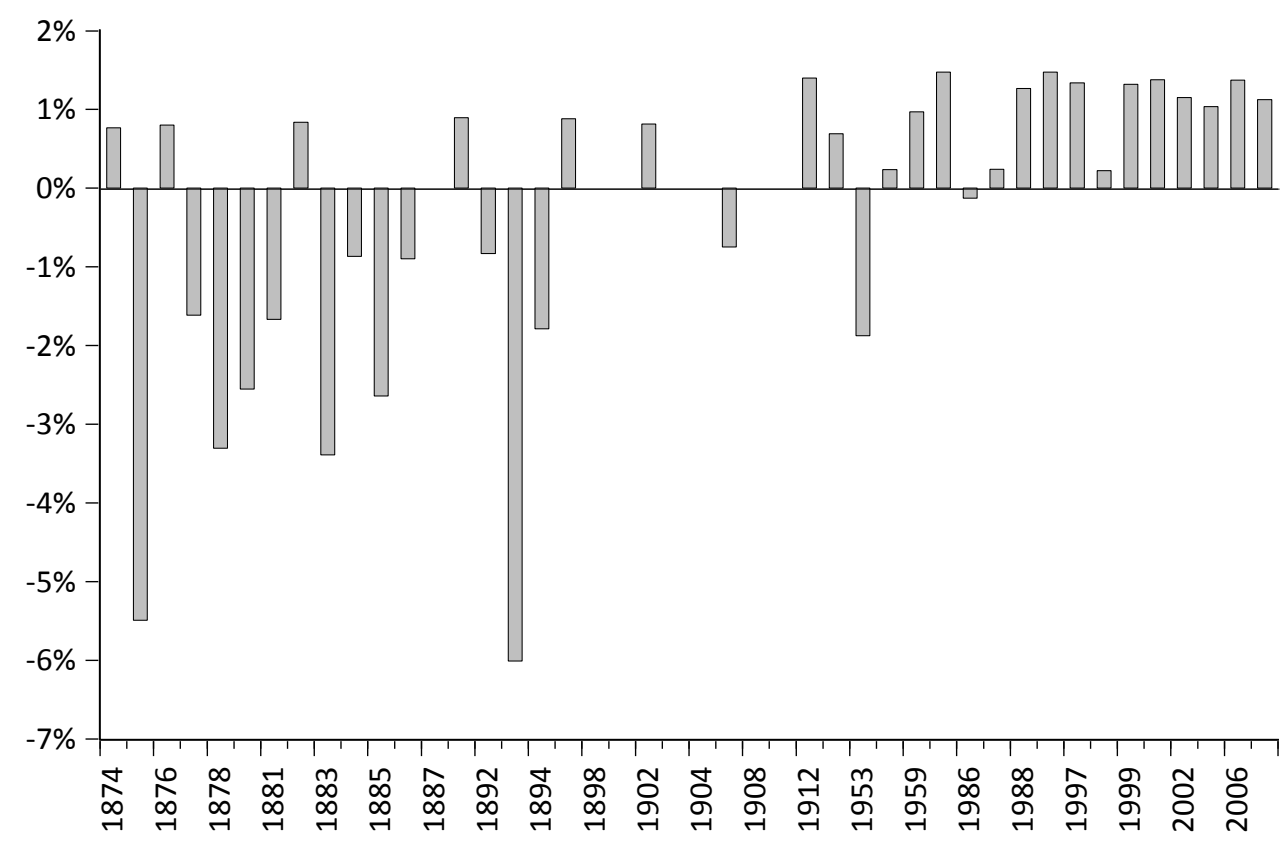


Figure 7A The Fed's Credibility Over Time: Recursive and Rolling Estimates

Estimates of Federal Reserve Credibility: Interest Rate Instrument

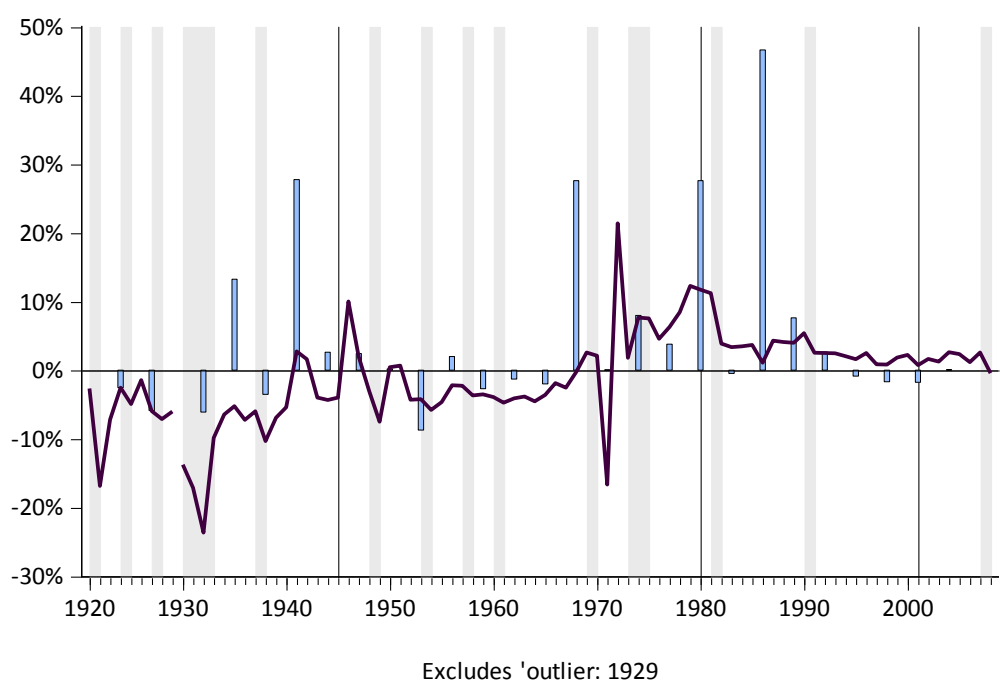

$\square$ Rolling-based estimates $\square$ recursive-based estimates

Estimates of Federal Reserve Credibility: Money Growth Instrument

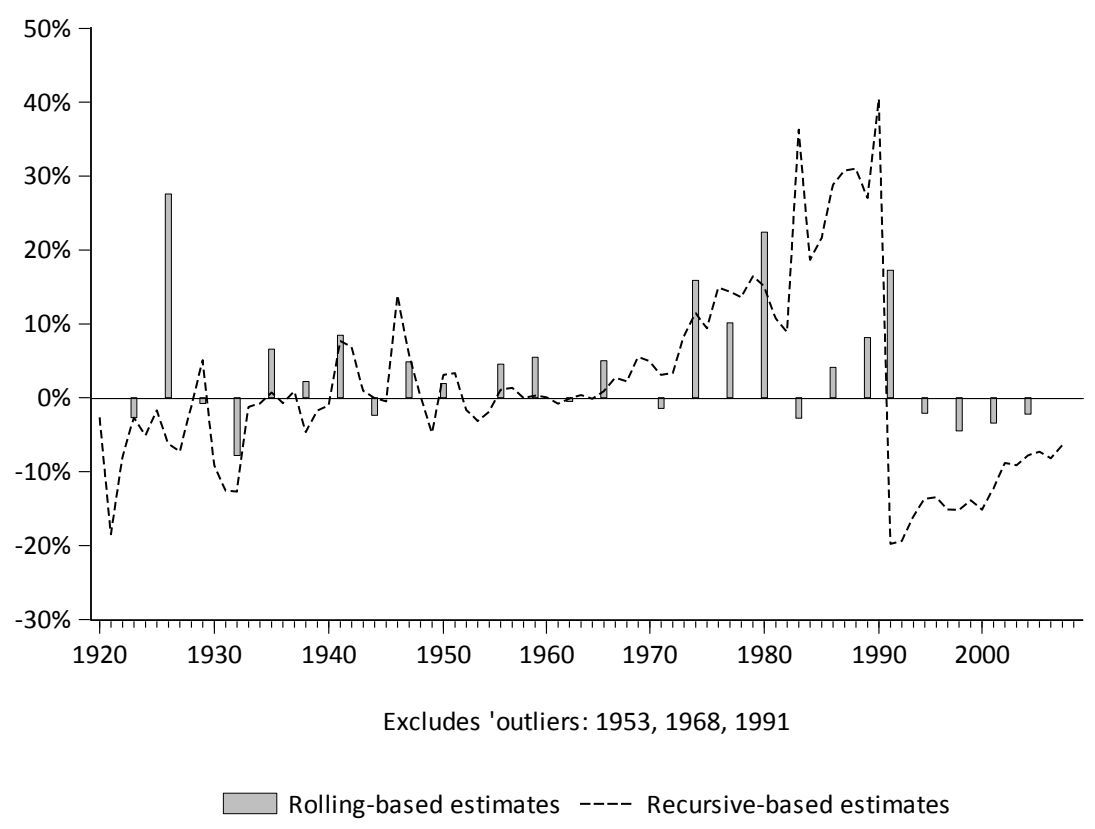




\section{Figure 7B The Bank of England's Credibility Over Time: Recursive and Rolling}

Estimates

Estimates of Bank of England Cre dibility: Interest Rate Instrument
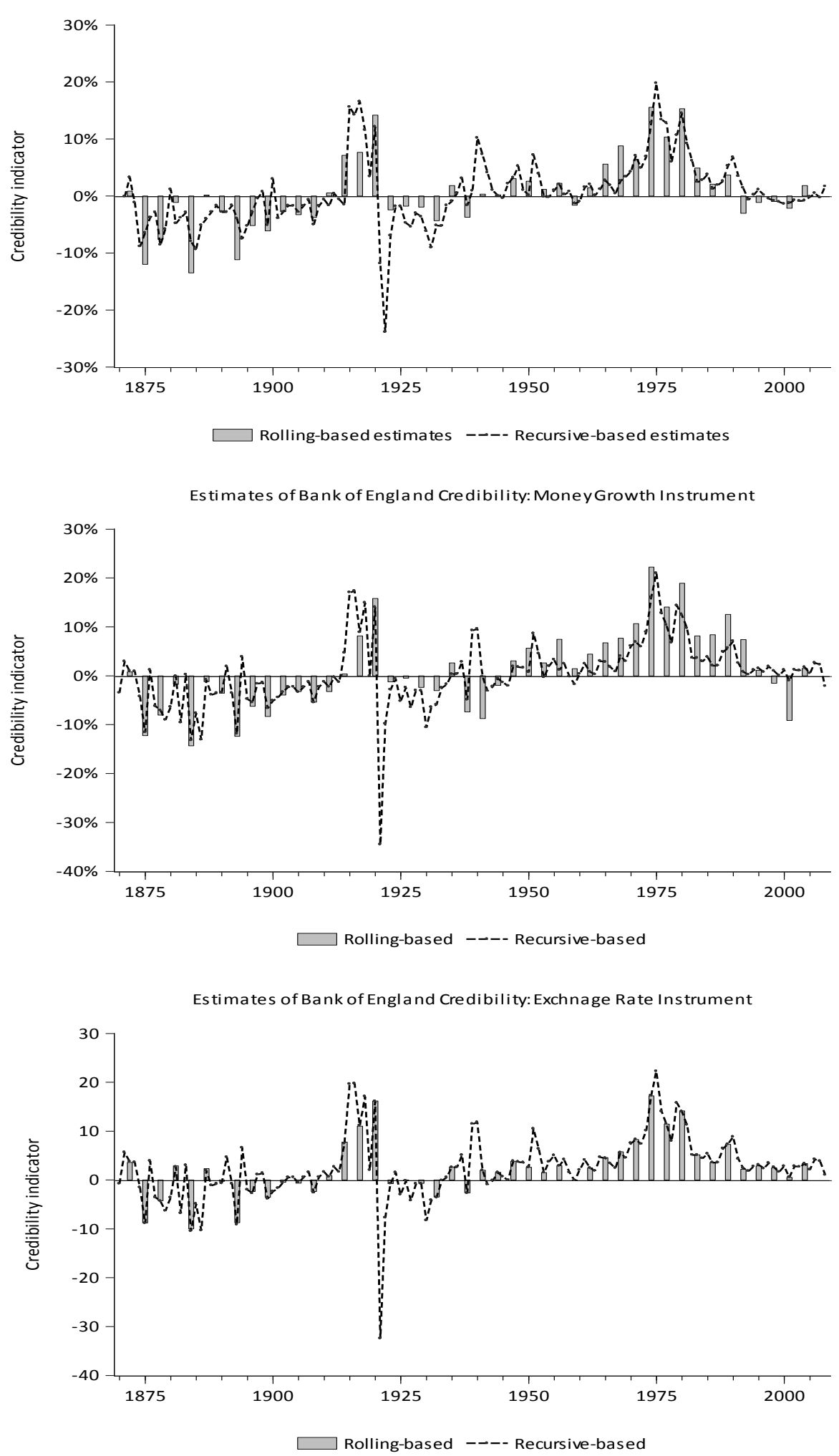
Figure 7C The Reichsbank's and the Bundesbank's Credibility Over Time:

Recursive and Rolling Estimates

Estimates of Reichsbank \& Bundesbank Credibility: Interest Rate Instrument

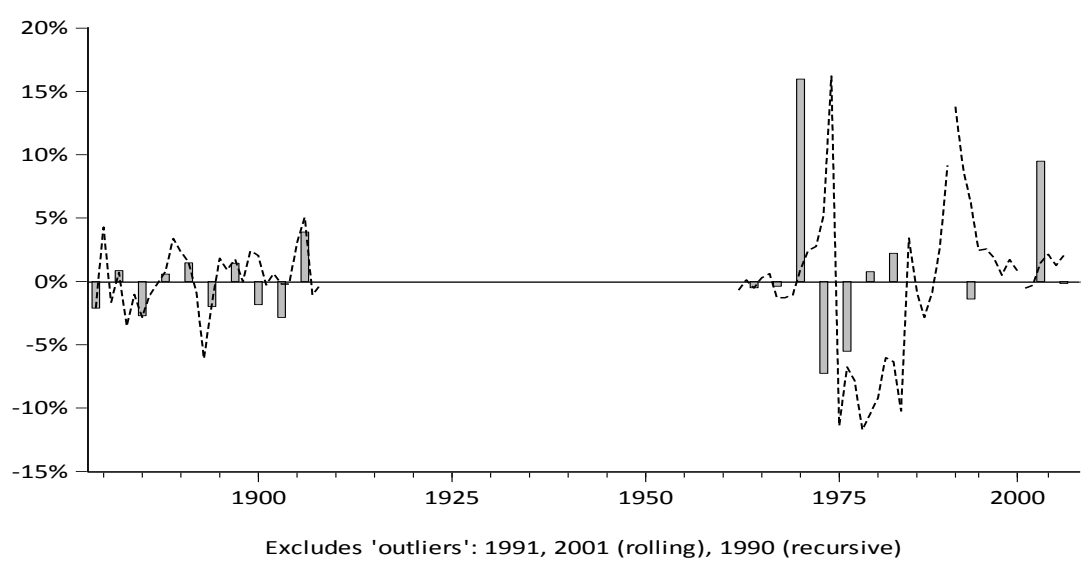

Estimates of Reichsbank \& Bundesbank Credibility: Money Growth Instrument

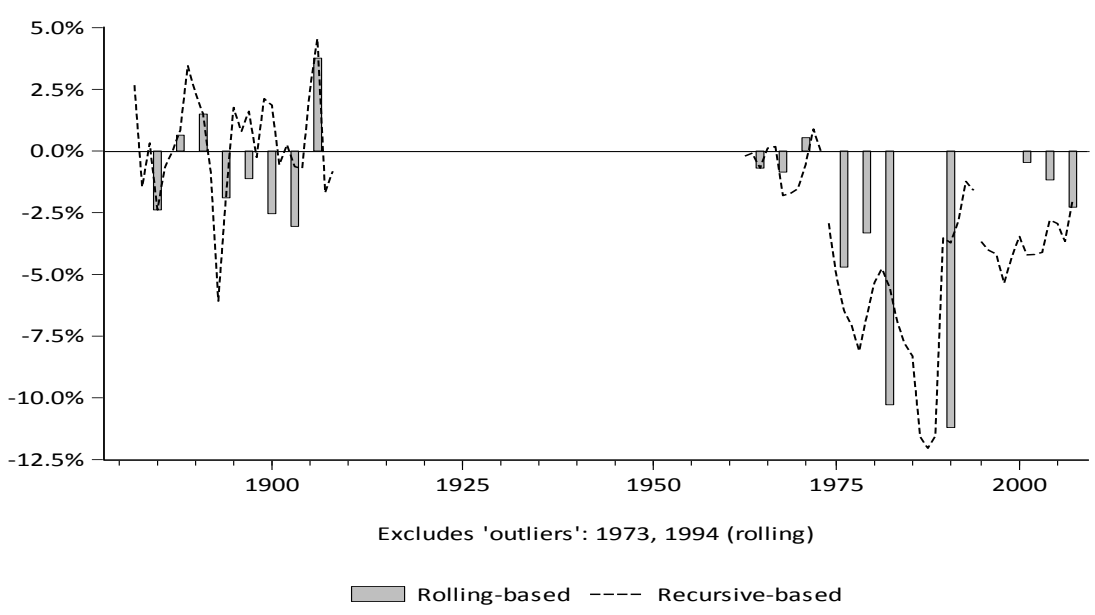

Estimates of Reichsbank \& Bundesbank Credibility: Exchange Rate Instrument

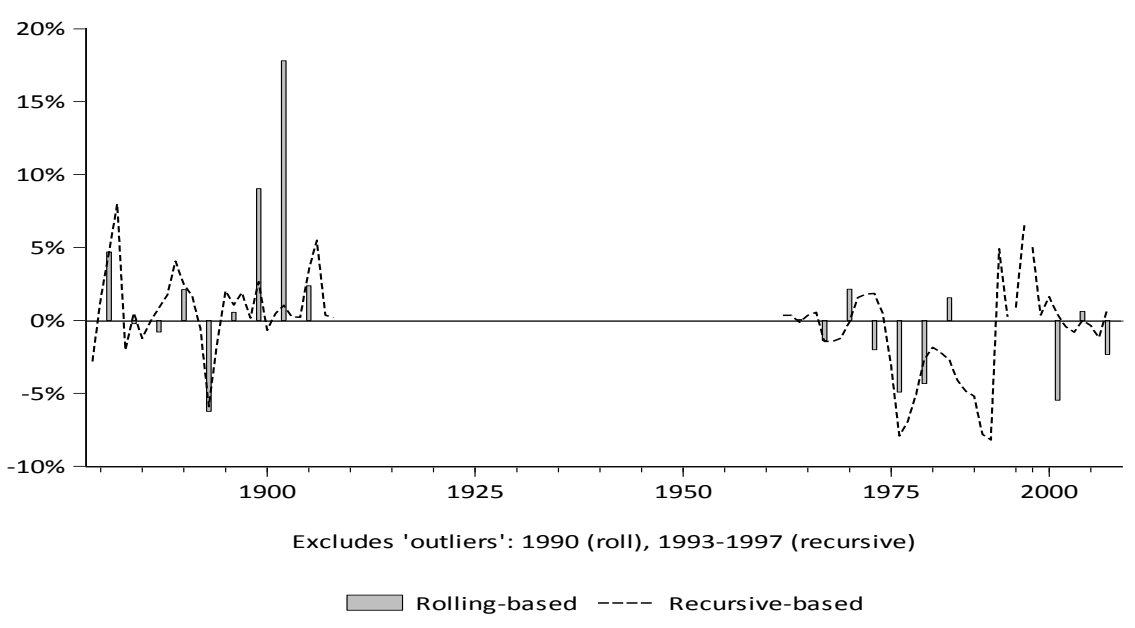




\section{Narratives}

\section{Sweden: The Riksbank}

The Sveriges Riksbank was founded in 1668 making it the world's oldest central bank. Like the Bank of England it was set up to provide government finance, then evolving over time as a bankers bank. In the nineteenth century, Sweden joined the gold standard in 1873 Sweden maintained gold convertibility and had price stability (with alternating periods of inflation and deflation) reflecting strong credibility until 1914. The Riksbank followed the rules of the game as well as most other countries (Jonung 1984). The Riksbank also acted as a lender of last resort in allaying financial crises in 1873 and 1907.

During World War I, although Sweden was neutral, she abandoned gold convertibility de facto until 1921. During the war, Sweden had high inflation reflecting gold inflows from the belligerents purchasing its commodities. Like the UK, Sweden followed a costly deflation to return de facto to the gold standard at the original parity in 1922, de jure 1924. The deflation contributed to a serious banking crisis in 1920 which the Riksbank handled well as a LLR. Prices declined through the 1920s. After the UK left gold in 1931 Sweden followed suit but the Riksbank began following the unorthodox policy of stabilizing the price level( following a price level rule) and maintaining stable prices throughout the 1930s ( Berg and Jonung 1999).

During World War II Sweden left the gold standard and like many countries imposed extensive exchange rate and price controls in the face of the large supply shocks it faced from the heavy demand for its resources by both the Germans and the Allies (Fregert and Jonung 2008). Sweden emerged from the war with ongoing inflation. Sweden, like many other European countries had an overvalued exchange rate in terms of dollars and it followed the UK in devaluing the krona in 1949.

Sweden joined the Bretton Woods system in 1951. Like the experience of other countries prices were relatively stable and the economy boomed. Sweden, following the war kept extensive capital and exchange controls and used the central bank to implement credit policy-the allocating of credit by non market means. Like other countries the Riksbank was subservient to the Treasury. 
After the collapse of Bretton Woods, Sweden followed an inflationary Keynesian full employment policy. It also accommodated both OPEC oil price shocks. In the face of these supply shocks and the inflationary response to them, Sweden was forced to devalue several times. According to Fregert and Jonung (2008) "the nominal anchor in the form of an ex ante fixed exchange rate for the krona quickly lost its ability to anchor long-run expectations ex post...the policy rule from the mid 1970s to the early 1990s has been characterized as a full employment policy rule accompanied by a wage price spiral caused by the use of devaluation to accommodate wage increases " page 16.

In the mid 1980s Sweden adopted a fixed exchange rate to the DM as an irrevocable nominal anchor. Adhering to this policy, once the DBB tightened monetary policy in 1991 led to a serious currency crisis /banking crisis in the fall of 1992 accompanied by a recession with high unemployment. This led the Riksbank to abandon the peg.

In January 1993, after switching to floating exchange rates, the Riksbank adopted an explicit inflation target at $2 \%$ (bounded on either side by $1 \%$ ) to be enforced after January 1995. This policy led to the greatest improvement in inflation credibility in a century measured by the length of wage contract (Fregert and Jonung 2008). The Riksbank began following a flexible inflation targeting regime-allowing supply shocks to affect inflation in the short-run and limiting fluctuations in the output gap. The Riksbank became independent in 1999. Sweden followed the Maastricht criteria of low inflation, fiscal deficits and debt ratios but stayed out of the Exchange Rate Mechanism (ERM). Sweden decided in a referendum in 1992 to not join the euro area when it would start in 1999 and has stayed out ever since. Based on the length of long-term contracts, Fregert and Jonung (2008) find that Sweden had credible inflation regimes in the Classical gold standard era, during Bretton Woods and during the inflation targeting regimes and possibly in the 1930s price stability rule period. They see the 1940s, 70s and 80s as unstable regimes.

\section{United Kingdom: Bank of England}

The Bank of England was founded in 1694. It was a private chartered joint stock bank with a public function. It was designed to aid the British government in placing its debt. In exchange for being the government's financier it was given the right to issue bank notes and to take on other private banking functions. Over time it evolved into a banker's bank, 
taking deposits from the nascent commercial banks because of its important position. The Bank's charter required that it keep its notes convertible into gold at the official price of $\mathrm{L}$ $3.17 \mathrm{~s} 9 \mathrm{~d}$ per ounce of gold. By maintaining gold convertibility, the Bank gained credibility early on.

The Bank had operational independence but not goal independence, ie its main goal was to stay on the gold standard but it had control of its main policy tool-Bank Rate ( the discount rate)-- and the government could monitor its performance since its charter was subject to periodic renewal.

The gold standard rule that the Bank followed in the eighteenth and nineteenth centuries was a contingent rule, in the sense that in times of emergency, such as major wars, the Bank could request permission from the Treasury to temporarily suspend convertibility and issue inconvertible bank notes, as was indeed the case during the Napoleonic wars, during which the Bank suspended convertibility in 1797 and restored it after hostilities had ceased, in 1821. Inflation reached a peak of $10 \%$ per year in 1810 and then declined to its prewar level by the time of Resumption. These actions ensured the Bank's credibility (Bordo and Kydland 1995).

During the nineteenth century the Bank evolved into a lender of last resort in the face of banking panics. In many crises, beginning in 1825 and ending in the Overend Gurney crisis of 1866 the Bank lent too little and too late. By the Baring crisis of 1890 the Bank finally learned to follow Bagehot's (1873) Responsibility Doctrine to subsume its private interest to its public responsibility (Bordo 1990). This also enhanced its credibility.

During the heyday of the Classical gold standard 1880-1914 the Bank generally followed the "rules of the game" using its main policy tool, Bank rate, to speed up the adjustment to balance of payments disequilibria. On occasion, to make Bank Rate effective, the Bank used open market operations and gold devices. (Bordo 1981). Because of its credibility the Bank had considerable flexibility to achieve goals other than convertibility, i.e to smooth interest rates, output and prices ( Bordo and MacDonald 2005).

World War I in August 1914 led to de facto suspension of the gold standard but not de jure until 1918. The Bank of England became an engine of inflation by freely discounting short term Treasury bills at a low pegged interest rate to aid the Treasury in its war finance. For a year after hostilities ceased, prices kept rising, at close to $200 \%$ in total. The 
British monetary authorities expressed a strong interest in restoring the gold standard at the original parity as soon as possible in the Cunliffe report of 1918. Resumption would require politically unpopular deflation. The Bank engaged in tight money beginning in 1919 and the UK returned to gold at $\$ 4.866$ in April 1925. Many argue that sterling was overvalued by at least $10 \%$. This overvaluation in one of the key reserve currencies, along with other flaws, meant that the reestablished gold exchange standard would prove to be not as durable as the classical gold standard but it was as credible, at least until 1931( Bordo and Macdonald ( 2002)

The gold exchange standard broke down in 1931 because of its major flaws of maladjustment, illiquidity and lack of confidence. Under a heavy speculative attack in summer 1931 the UK left the gold standard. The UK's experience with deflation and depression was much less than other countries like the US that had continued to stay on gold (Eichengreen 1992). After Britain had left gold, devalued and floated sterling the Bank embarked on a reflationary policy through the 1930s.

During the Second World War the Bank again became an engine of inflation and subsumed its independence to the Treasury. This led to a period of high inflation which carried through into the 1950s. The Bank was nationalized in 1945 and officially lost whatever independence it had. The UK became part of the Bretton Woods system in 1946 but did not achieve current account convertibility until December 1958. The 1950s and 60s was a period of stop go monetary policy. Like in the interwar, sterling was overvalued and the UK ran persistent balance of payments deficits, often culminating in currency crises, ended by international rescues. Once the balance of payment constraint was relaxed the monetary and fiscal authorities would stimulate the economy leading to a run up of prices and another sterling crisis. The stop go pattern ended after the Devaluation of 1967 which also ended sterling's role as a reserve currency (Bordo 1993).

During the 1950s and 60s it was widely believed in the UK that monetary policy was impotent as described in The Radcliffe Committee Report of 1960. Radcliffe advocated the use of credit allocation policy and fiscal policy rather than monetary policy to maintain full employment (Capie 2010).

After the Bretton Woods system broke down between 1971 and 1973, sterling floated and without an external nominal anchor the UK entered the Great Inflation reaching 
inflation rates over $20 \%$ and a total loss of credibility in the later 1970 s. The Treasury, which controlled monetary policy, believed inflation was caused by non monetary, cost push forces and advocated the use of incomes policies rather than tight money to allay it (Dicicio and Nelson 2013).

The high inflation rate produced a major currency crisis necessitating an IMF rescue in 1976. The inflation spiral was finally ended in 1980 when Margaret Thatcher came to power. Thatcher and her advisor Alan Walters adopted monetarist orthodoxy and greatly reduced money growth, liberalized the financial system, and removed capital controls. This led to a serious recession in 1980-81 but by the mid 1980s the policy broke the back of inflation and inflation expectations as was occurring at the same time in the U.S. Like the US, this was the beginning of a period of low inflation, later called the Great Moderation. However unlike the Volcker Fed, the Bank of England did not have independence. That did not occur until 1998 when it achieved operational but not goal independence from the Treasury. The UK Treasury and the Bank in the 1980s and 19990s had the primary goal of low inflation and, following New Zealand's example, began formal inflation targeting in 1992. Since then the UK has generally had low inflation and anchored inflationary expectations.

\section{France: Banque de France}

The Banque de France was founded in 1803 by Napoleon Bonaparte to restore France to monetary discipline after decades of instability and high inflation. France returned to bimetallic specie convertibility and the Banque was a successful guardian of the Bimetallic system until 1878 when France switched to the gold standard. Specie convertibility was maintained until 1914 with two interruptions: in 1848-1850 following the overthrow of the July monarchy and 1870-1873 following the Franco German War. France adhered credibly to the specie standard as a contingent rule (Bordo and Kydland 1995) and like the UK and Germany maintained price stability. The Banque de France did not follow "the rules of the game" as closely as did the Bank of England and rarely varied its discount rate but its unconventional (credit rationing) policies did not threaten its credibility (Bordo and MacDonald 2005). The Banque de France also learned to be an effective lender of last 
resort in allaying financial crises in 1882 and 1889 (White 2007, Hautcoeur, Riva and White 2014).

France left the gold standard during World War I and like the other belligerents, the $\mathrm{BdF}$ became an engine of inflation, freely absorbing the government's debt and maintaining a low interest peg. France had a higher inflation rate than Britain and the U.S .during the war (at well over 200\%). After the war, the BdF and the Treasury favored returning to its prewar parity but the inflation and debt overhangs were so high that it would have taken a massive deflationary policy to achieve it (Bordo and Hautcoeur 2007). More importantly a struggle between the left and the right on how to reduce the debt and restore fiscal balance prevented any action. The BdF continued absorbing the government's debt and inflation mounted until 1926. In 1925 the Banque's reputation was tarnished in a scandal for falsifying its statement of its circulation leading to the fall of the incumbent government (Johnson 1997). By 1926 France had a serious currency crisis which was resolved by Poincare arranging a political deal to restore fiscal balance, aided by international loans. France returned to gold de facto with an $80 \%$ devaluation of the franc. Thereafter until 1936 the BdF followed a very conservative, hard franc policy to keep France on the gold standard. During the Great Depression France stayed on the gold standard after Britain and the US had departed. It was able to do this because until 1934 the franc was undervalued. In the next two years France, like the other members of the gold bloc faced increasing competitive pressure from the devalued sterling and dollar blocs culminating in a currency crisis in 1936. To prevent a disorderly devaluation, France, the US and Britain signed the Tripartite agreement under which the three countries coordinated intervention in their currencies to smooth the franc's descent (Bordo, Humpage and Schwartz 2014 chapter 3). In sum, in stark contrast to the pre 1914 gold standard, the BdF's credibility was generally at a low level.

During World War II, occupied France had high inflation which continued after the war. At war's end in 1945, The Banque was nationalized losing its independence. In the early postwar period the BdF followed an inflationary policy to spur economic growth and maintain social stability. The Banque used credit rationing policies rather than the conventional tools of monetary policy. Such policies continued through much of the next 
three decades. According to Monnet (2013) the pursuit of such policies did not in general achieve worse countercyclical outcomes than would be the case with conventional tools.

France joined the Bretton Woods system in 1946. In the face of high inflation, parity was suspended in 1948, then restored following a devaluation in 1949. The experience was repeated in 1957 and 1958. Important fiscal reforms were instituted in 1958 which allowed France to declare current account convertibility in December 1958. In early 1960 a currency reform created the New Franc worth 100 old francs. The BdF maintained relatively low inflation in the 1960s and in 1963-64 President DeGaulle and Jacques Rueff began campaigning to convert the Bretton Woods gold dollar exchange standard into a pure gold standard. Until 1967 France continually challenged US hegemony and undermined the Bretton Woods system (Bordo, Simard and White 1995).

In spring 1968 political unrest led to a currency crisis which despite an international rescue, ended with another devaluation of the franc. After the collapse of the Bretton Woods system France's participation in the "Snake in the Tunnel" exchange rate arrangement was unsuccessful because of France's high inflation rate relative to Germany's . Like many other countries, France had high inflation in the 1970s. Despite the BdF's adoption of monetary targeting, it accommodated the oil price shocks. France joined the European Monetary System in 1979 as a credibility enhancing mechanism but the franc still remained weak relative to the deutschemark. In 1983 France adopted the "franc fort" policy with tight monetary policy by the BdF. Subsequent disinflation restored some credibility. However it was short lived as the EMS crisis in 1992 ended with France's exit and devaluation of the franc. France signed the Maastricht Treaty in 1992. The Banque was granted independence in 1993 and became fully committed to price stability. For the next six years until EMU and the creation of the euro in 1999, the Banque followed a credible policy of low inflation.

\section{Norway: Norges Bank}

The Norges Bank was founded in 1816 when Norway was made independent from Denmark. The Nineteenth century, after the end of the Napoleonic Wars, was one of price stability for Norway as was the case in the other Scandinavian countries. Norway was on a 
silver standard until 1873 when it joined the gold standard. Norway was also part of the Scandinavian Monetary Union from 1875.

Prices tended toward long run price stability because of adherence to a specie based nominal anchor. However prices were not perfectly stable from year to year reflecting global demand and supply shocks to specie and the operation of the price specie flow mechanism. Like the other Scandinavian central banks, the Norges Bank continued to have credibility for low inflation in the years preceding World War I (Eitrihem,Qvigstad and Steie 2006)

Like the other Scandinavian countries, Norway left the gold standard during World War I and had high inflation reflecting the belligerents demand for its goods and services. After the war Central bank Governor Rygg vigorously pursued a deflationary policy to restore the exchange rate to its original parity in 1928. The drastic deflation in the 1920s was associated with high unemployment and falling output. Like Sweden and other countries Norway left the gold standard after Britain did in September 1931. The Norges Bank then pursued an expansionary policy in the 1930s.

During World War II Norway was occupied by the Germans. As in the case of other occupied countries, the central bank used the inflation tax to provide revenue to be transferred to the occupiers. The inflation was accompanied by extensive controls and hence was repressed.

After the War Norway joined the Bretton Woods System in 1946. The next two and a half decades were periods of rapid economic growth (partly fueled by Marshall Plan aid) and low inflation. Norway left Bretton Woods in 1971 and the 1970s and 80s was a period of high inflation associated with expansionary monetary and fiscal policy dedicated to maintain full employment. The Norges Bank, like other central banks in this era believed in the Phillips curve tradeoff between unemployment and inflation. As a consequence of these inflationary policies and continued adherence to fixed exchange rates Norway had periodic devaluations. Like Sweden, the Norges Bank was involved in the government's credit allocation policies which were accompanied by extensive controls on financial markets (Eitriheim and Oksendal 2013)

Liberalization of the financial sector was lifted in 1984 which contributed to a real estate boom, fueled by expansionary monetary policy. The boom ended with tighter 
monetary policy in 1986. The legacy of the collapse of the real estate boom and the buildup in bad assets in the commercial banks was a banking crisis in 1991 when the Norges bank served as an effective lender of last resort (Steigum 2009).

A major policy reform occurred in 1986, The Norges Bank became dedicated to price stability as its main goal. The Norges Bank received operational independence in 1985. The reforms and new policies were successful in reducing inflation and the Norges Bank gained credibility. This was strengthened when the Bank began targeting inflation in 2001. Since the late 1980s the Norges Bank has been very successful at keeping inflation low and price expectations well anchored (Qvigstad 2013).

\section{Germany: Reichsbank/Bundesbank}

The Reichsbank was founded in 1876 shortly after the Franco Prussian War, German reunification and Germany's joining the gold standard. The Reichsbank had private ownership but public management (Singleton 2008). It had operational independence within the confines of the gold standard. It was established to unify the currency, preserve gold convertibility, act as a central bank (to use its discount rate to provide liquidity for the money market based on bankers acceptances) and be a lender of last resort.

The Reichsbank was successful in maintaining the gold standard until World War I and it generally followed the rules of the game (Bordo and Eschweiler 1994). It also was a successful lender of last resort in the financial crises of 1901 and 1907. Thus the Reichsbank had considerable credibility and the German price level was well anchored.

Germany abandoned gold convertibility at the start of World War I and the Reichsbank became part of the government. It freely discounted government paper at a low interest rate peg, becoming a major engine of inflation. After defeat in 1918 the Reichsbank under its President Havenstein continued to be an engine of inflation which became hyperinflation by 1923. The basic problem was an impossible fiscal impasse in which the Weimar government could not raise the tax revenues needed to pay for reparations and postwar reconstruction and other expenses so it resorted to the printing press. By 1923 the Reichsbank lost its credibility and the German mark became worthless. In the Currency Reform of 1923, Havenstein was succeeded by Hjalmar Schacht as President of the Reichsbank. In 1924 the Reichsmark was created, fiscal balance was restored with the aid 
of massive foreign loans, and the currency was pegged again to gold at a vastly devalued rate from its prewar parity. For 7 years Germany had price stability and credibility was restored (Bordo and MacDonald 2002). Schacht cooperated with Montagu Norman (Governor of the Bank of England), Emile Moreau (Governor of the Banque de France, and Benjamin Strong (Governor of the Federal Reserve bank of New York) to maintain the Gold Exchange Standard (Ahmed 2010).

The Great Depression, which began in the US, spread quickly to Germany, which had borrowed heavily in the US and quickly lost access to the foreign capital inflows needed to service reparations. Germany had as serious a contraction and deflation as the US. The Reichsbank, following gold standard orthodoxy maintained a tight monetary policy making things worse (Eichengreen 1992). The Creditanstalt crisis in Vienna in May 1931, which led to a bailout by the Austrian National Bank and government, provoked a run on the Austrian schilling, a freeze on foreign deposits and the imposition of exchange controls( which de facto removed Austria from the gold standard).The banking crisis then spread to Germany in July 1931. The German government bailed out most of the commercial banks, froze foreign deposits and like Austria imposed exchange controls and de facto left gold. The German financial crisis and the Depression contributed greatly to the victory of National Socialism in the elections of 1933. Under Hitler, the Reichsbank became the government's bank and greatly helped finance rearmament and then World War II. The Bank instituted a panoply of internal and external controls. World War II led to high (and suppressed) inflation which continued after defeat.

After the war, the allies established the Deutsches Lander Bank, which like the early Federal Reserve was a loose federation of regional banks coordinated by a Board. The BdL was dedicated to preserving the value of the currency (both external and internal). It was made independent from the Federal Government. The Currency Reform of 1948 ended inflation and created a new currency, the Deutschemark. The BdL based on the stability culture of postwar Germany focused primarily on price stability and led Germany into a pattern of low inflation. (Beyer et al 2013).

The BdL was superseded by the Bundesbank (DBB), established by the Federal Government of Germany in 1958. Like its predecessor it was dedicated overall to maintaining the value of the DMark. Under the Bretton Woods System the DBB faced a 
conflict between maintaining the dollar peg and internal price level stability since under a pegged exchange rate the money supply becomes endogenous. In the Bretton Woods era , West Germany ,because of its rapid productivity growth and high growth rate, kept running current account surpluses which would lead to dollar inflows, which unless they were sterilized would lead to faster money growth and inflation. In response to the inflationary pressure Germany imposed controls on capital inflows and revalued the DM in 1961 and 1969 (Bordo 1993). Once the Bretton Woods system broke down between 1971 and 1973, The DBB began to focus on maintaining the internal value of the DM. Its attempts to maintain price stability were not successful with the first Oil Price shock in 1973 when inflation rose to 8\% per year. In 1974 the DBB adopted monetary growth targeting to gradually reduce inflation. The monetary targeting framework was supposed to both control inflation and influence inflation expectations. The DBB roughly followed monetarist doctrine in targeting Central Bank Money (similar to M3) and gradually reducing its targets, but it often missed its targets. According to Beyer, et al 2013) although the DBB missed its targets, it always explained the misses and hence followed pragmatic monetarism. The DBB's policy did succeed in making Germany's inflation rate (along with Switzerland) by far the lowest among the advanced countries during the Great Inflation. The experience of low inflation and the fact that Germany did not accommodate the second oil price shock in 1978/79 gave the DBB very high credibility before the 1980s, in sharp contrast to the US and UK.The DBB kept following money targeting until the advent of the Euro in 1999. The DBBs monetary targeting approach and its credibility for low inflation were incorporated into the European Central Bank as its two pillar strategy.

\section{Italy: Banca d'Italia}

Italy was unified in 1861 but the Banca d'Italia was not founded until 1893. Italy had competing banks of issue for its first three decades which meant that it was difficult to create a uniform national currency or to conduct national monetary policy Fratianni and Spinelli( 1997). Italy initially adhered to the bimetallic standard until 1883 when it joined the gold standard. It also was a member of the Latin Monetary Union. Italy had a chequered specie adherence and inflation record until the end of the nineteenth century. Lax fiscal and monetary discipline, initially consequent upon war with Austria, led it to abandon specie 
from May 1861 to March 1883, float its exchange rate and issue inconvertible fiat money, and then return to the gold standard from 1883 to June 1893. It again left gold and floated from 1893 to 1902 (Bordo and Schwartz 1996). Thereafter although Italy did not join the gold standard the Bd'I began following a conservative monetary policy which kept the lira close to its de facto parity and the government greatly reduced its fiscal deficits so that Italy shadowed the gold standard (Tattara 2000).

During World War I, along with other belligerents, The Banca d'Italia served as an engine of inflation, which peaked at 44\% in 1917. Shortly after the war ended, Mussolini came to power in 1922 and the central bank lost its autonomy to the Treasury and inflation continued. In the late 1920s the monetary authorities followed a tight monetary policy to produce a strong lira and Italy joined the gold exchange standard in 1928. Like other gold bloc countries Italy stayed on gold until 1935 which imposed deflationary pressure on the Italian economy. The lira was devalued in 1936 and Italy adopted a fiscally dominant inflationary policy which culminated in very high inflation, peaking at $90 \%$ per year in 1944 (Fratianni and Spinelli 1997).

After its defeat in World War II, Italy was plagued by high inflation and deep recession. The B d'I began a stabilization policy in 1947. Italy joined the Bretton Woods system in 1946 and the Bd'I was successful for a number of years in maintaining the official peg, leading to current account convertibility in 1960. However expansionary financial policy inconsistent with the peg, led to a currency crisis in 1964 which was resolved with an international rescue package (Yeager 1976). Italy adhered to Bretton Woods until it collapsed in 1971. In the 1970s, Italy returned to a fiscally dominant regime, with high and variable inflation, a serious currency crisis in 1976 requiring an IMF rescue and conditionality and unsuccessful adherence to the European "snake in the tunnel "arrangement.

Italy joined the EMS in 1979 as an inflation disciplining device (Giavazzi and Pagano (1991). although its inflation rate remained one of Europe's highest, and it was forced to exit the ERM in the currency crisis of 1992. Italy signed the Maastricht Treaty in 1992, and by 1999 its inflation rate, debt to GDP ratio and fiscal deficit sufficiently to allow it to join the euro. The Banca d'Italia became operationally independent in 1992 but never formally adopted an inflation target before it was absorbed into the ECB. 
In sum, with a few exceptional episodes, the Banca d'Italia's credibility for low inflation was not stellar before joining the euro. Indeed Italy was a strong advocate for EMU because it would have an externally imposed nominal anchor to give it such credibility.

\section{Switzerland: The Swiss National Bank (SNB)}

The Swiss National Bank was founded in 1907. Unlike the earlier European National Banks of Issue established in the nineteenth century or earlier, the SNB was set up to adhere to the monetary standard and to provide financial stability. Switzerland was on gold since 1878 but was still a member of the Latin Monetary Union and in the nineteenth century had issues with depreciated Italian silver coins and with its currency being weaker than the French Franc (Bordo and James 2007). Like the Federal Reserve the SNB was to follow the real doctrine and freely discount eligible real bills from the Swiss commercial banks.

Like other European countries, Switzerland left the gold standard in 1914 and had high (internationaly driven) inflation in the war although she was not a belligerent.

Following the War the SNB followed a deflationary policy to restore gold, de facto in 1924 and de jure 1929. As an important banking center, Switzerland was exposed to the crisis of the Great Depression. Several important banks faced stringency in 1931 and the SNB provided liquidity support. Switzerland stayed on the gold standard, along with France and the other gold bloc countries (Belgium, Netherlands and Poland) and began to suffer competitive pressure after Britain and then the United States left gold and floated. Political debate between advocates of devaluation and proponents of hard money only ended when France left gold and Switzerland followed. Had Switzerland devalued earlier along with the U.S., its real output would not have fallen nearly as much as it did (Bordo, Helbling and James, 2007).

Switzerland remained neutral during World War II. After the war, Switzerland, like Germany followed the stability culture and the SNB had an excellent track record at keeping inflation low. Switzerland did not join the Bretton Woods System but the Swiss franc was defined as a specified weight in gold so it had its own nominal anchor. Switzerland like Germany because of its low inflation ran continuous balance of payments surpluses which led to inflationary pressure. Unable to sterilize the dollar inflows, 
Switzerland like Germany imposed capital controls (taxes on foreign deposits). As the Great Inflation progressed and the weak dollar became more of a problem, Switzerland joined the other European countries and allowed the SF to float in 1973. Like the DBB, the SNB followed a monetary targeting strategy with the monetary base as a target (Rich 1997) and the SNB was as successful as the DBB in keeping its inflation rate lower than other advanced countries. The SNB's credible track record for low inflation combined with Switzerland's efficient banking sector (and secrecy laws) made the SF a key haven for capital flows from the rest of Europe and the less developed world. The inflows put upward pressure on the SF and made it difficult for the SNB to hit its monetary base target so that in 1978 it had to temporarily suspend its target. The SNB was generally able to hit its target until 1986, after which external shocks put upward pressure on the SF, on money supply and prices. Forcing Switzerland to abandon its base control strategy and to shift to inflation targeting in 1999 while still monitoring monetary aggregates as predictors of future inflationary pressure (SNB 2007). The SNB has maintained credibility for low inflation and has anchored inflation expectations for much of its history.

\section{Australia: The Commonwealth Bank of Australia/The Reserve Bank of} Australia

Although the RBA dates from 1959 central banking actually began with the Commonwealth Bank of Australia (CBA) in 1912. The CBA was publicly owned but operated much like a conventional commercial bank (Gollan 1968). The original concept stemmed from boom and bust cycles due to Australia's position as a commodity producer and the purpose of the new bank was to act as a backstop of sorts in the event of bank failures, a common occurrence in the 19th century. From the outset there was considerable discussion about the independence of the CBA. Politicians felt that the CBA ought to be independent of political interference as it sought to deepen financial markets and spur economic development not act as a too of the politicians (e.g., Bell 2004). A common development across many of the central banks covered by our narratives is that, during major wars, the monetary authorities became, if they not already, subservient to the Treasury. The CBA was no exception (e.g., see Swan 1940). However, it is also true that war 
finance provided an opportunity for the institutional development of the monetary authority, especially as a 'restraining influence' (Bell 2004, p.9) on government finance.

Like its counterparts elsewhere in the Dominions, the CBA was affected by the Great Depression and, when the Gold Standard ended in 1931, the CBA was given authority over the exchange rate. Moreover, just as in Canada, the subject of conflict between the Governor and the central bank became an important topic of reform. While a crisis on the same level as the Coyne Affair in Canada did not take place, the government in the early 1950s eventually introduced a dispute resolution mechanism designed to defuse tension and avoid damaging the government. It is interesting that Australian politicians of the time understood that conflict would likely first damage a sitting government and not the central bank. In contrast, politicians in Canada would not understand the consequences of conflict with the central until after the Coyne Affair erupted (e.g., see Siklos 2002). Just as with Canada there has never been a conflict serious enough to appeal to the legislation to resolve any dispute.

Initially, as in the case of New Zealand and Canada, the remit of the central bank did not contradict the goal of price stability (i.e., the stability of the currency) but there was a clear requirement to support economic growth as well. By the 1970s the oil price shocks were producing higher inflation rates while the abandonment of the Bretton Woods exchange rate system, together with interest rate ceilings and heavy handed banking regulation promoted the growth of the non-bank financial sector. By the late 1970s and into the early 1980s, a financial deregulation phase was being initiated culminating with the float of the dollar in December 1983. Through the use of open market operations and the ban on funding any government budget deficit the RBA was able to influence interest rates and autonomously set the stance of monetary policy.

The 1980s would eventually bring the start of major changes in the role of the RBA. Paul Keating, who became Treasurer in 1983, was determined to fight inflation. At the RBA this led to sharp rises in the policy rate, called the cash rate, reaching a peak of over $18 \%$ by the end of 1985. In addition, the RBA intervened regularly in foreign exchange markets to prevent the dollar from falling too quickly since this was deemed to be unhelpful (RBA 1987). Adding to the difficulties faced by monetary policy, especially during the late 1980s, were rapidly rising housing prices and a large current account deficit. However, at the same 
time inflation rates began to drop quickly and, in the space of roughly six years went from near double-digit rate of change to around 2\% by 1992.

In spite of an improved inflation record the RBA entered the 1990s with low credibility. It had been unable to counter the effects of boom and busts in the 1980s, there was no clear policy framework, supported incomes control policies, and was not seen as independent of government influence. The policy of gradualism, implicit in how monetary policy was delivered, lost favor.

By 1993, shortly after New Zealand, Canada, and the UK did the same, the RBA adopted an inflation target as an anchor of policy. However, in an important departure from the practice elsewhere of declaring an inflation target range with the aim of achieving the midpoint of the target over a specified horizon, the RBA chose to adopt a narrow range of 2$3 \%$, on average, over the cycle. Part of the reason was that, as did the RBNZ and the BoC, there was sufficient uncertainty about whether the target would be reached to adopt as flexible an approach as was feasible under the circumstances. By the mid-1990s a new government ushered in some modifications in the inflation targeting policy by requiring that the Treasurer and the RBA Governor agree on the inflation targeting strategy. The resulting Statement on the Conduct of Monetary Policy has become a fixture of monetary policy making since that time (Grenville 1996).

Inflation has been low and stable since the mid-1990s in Australia and there are no indications that the monetary policy strategy will change. Unlike many other central banks Australia did not experience a recession following the GFC of 2008-9. However, the commodity price boom, together with an asset price boom, primarily in he housing sector, made life difficult for the RBA. Policy rates were raised and lowered relatively gradually through the crisis and in response to the housing price boom but the RBA never flirted with the ZLB. Nevertheless, while the economic problems Australia has faced for decades, namely boom and bust cycles in commodity and asset prices, remain the RBA has now achieved an enviable record of low and stable inflation thanks to inflation targeting (e.g, see Stevens 2003), its independence is not in doubt, and its committee-based decision making structure is consistent with best practice in monetary policy making.

\section{United States: Federal Reserve}


The Federal Reserve was established in 1913 to act as a lender of last resort and to preserve the gold standard. The U.S. hadn't had a central bank since the demise of the Second Bank of the United States in 1836. The U.S. had been on a specie standard (bimetallism before 1873, gold thereafter) standard throughout the nineteenth century with the exception of the Greenback paper money floating exchange rate episode from 1862 to 1879 . Under the gold standard, the U.S. had long-run price stability (alternating periods of rising and falling prices driven by the vagaries of the gold standard). The U.S's inflation credibility was nearly as good (with the exception of the Free Silver threat in the early 1990s) as the advanced countries of Europe which had central banks (seen in longterm interest rate spreads on gold bonds Bordo and Rockoff 1996). The main problem in the U.S. was financial instability manifest in frequent banking panics $(1837,1857,1873$, 1884, 1993 and 1907) in the absence of a true lender of last resort.

The panic of 1907 was the event that broke the camel's back leading to the movement for monetary reform. The prototype for a US central bank was contained in the Warburg Plan of 1910-a loose federal system of regional central banks, each modeled after the Reichsbank in Germany to be coordinated by a Board in Washington. The Reserve banks would use their discount rates to freely accommodate banker's acceptances and act as a lender of last resort. The Federal Reserve System founded in 1913 took on many of the aspects of the original Warburg Plan with a much stronger federal government presence in the Federal Reserve Board (Bordo and Wheelock 2013).

World War I broke out just before the Fed was to open its doors leaving the U.S. as one of the few countries still on the gold standard (with the exception of a gold embargo 19171919). Gold inflows from the belligerents' purchases of US goods fueled inflation which was aggravated after the US joined the war in April 1917 when the Fed began financing the US Treasury's bond issues at a low pegged interest rate. By wars end the US price level had increased close to $100 \%$, (the lowest rate of the belligerents).

After the war the Fed began sharply raising its discount rate in 1919 after its gold reserves were threatened by continued high inflation. This led to a serious but short-lived recession and deflation from 1920-21. The period 1921 to 1929 was characterized by mild deflation and rapid economic growth punctuated by two mild recessions. Friedman and Schwartz (1963) and Meltzer (2003) gave the Fed high marks for attenuating the 
recessions, preventing banking panics and preserving price stability. The 1920 s can be regarded as a period of high Federal Reserve credibility.

The Great Contraction, 1929 -33 can be attributed to several failures of US monetary policy. These include loose monetary policy in 1927 to aid the UK in its struggles to stay on the gold exchange standard which may have fueled asset booms in housing and later stocks (Bordo and Landon Lane 2013); Fed tightening in early 1928 to stem the stock market boom which contributed to a downturn in August 1929 followed by the stock market crash of October; c) the failure to act as lender of last resort and prevent four banking panics from October 1930 to March 1933. This policy failure contributed greatly to an unprecedented collapse in money supply, real output and prices. The massive (over 30\%) decline in prices led to a major loss of credibility.

The Great Contraction ended in March 1933 and recovery followed quickly after the incoming Roosevelt administration declared a one week banking holiday, exited the U.S. from the gold standard, engaged in massive gold( and silver ) purchases and then devalued the dollar by $60 \%$ a year later. Prices and real output rebounded rapidly from 1933 to 1937 , interrupted by a sharp recession 1937-38 which Friedman and Schwartz (1963) attribute to the Fed's doubling of reserve requirements in 1936 to absorb banks excess reserves and the Treasury's policy of sterilization of gold inflows.

The Federal Reserve system was reorganized in 1933 and 1935 and the Board of Governors was given enlarged powers. However during the 1930s the Fed did not play a very active role in monetary policy which had been taken over by the Treasury. From the 1930s onward the Fed began following a low interest rate policy to accommodate the Treasury's fiscal policies (Meltzer 2003). During World War II the Fed again became an engine of inflation although prices did not rise as much as in World War I because of extensive price controls. The interest rate pegs were kept after World War II and in the 1940s inflation became a problem leading the Fed to campaign to regain its independence to raise its policy rates. This was achieved after a considerable struggle with the Treasury and the Administration in the Federal Reserve Treasury Accord of 1951. The Fed tightened policy in the early 50s and restored price stability. Under Chairman Martin the Fed followed a policy of low inflation and the economy performed well through much of the 
1950s and early 60s. During this period the US performed well in keeping inflation low as the provider of the key currency of the Bretton Woods System .

The era of credible inflation ended after 1965 when, under pressure from the Johnson administration the Fed began accommodating expansionary fiscal policies to support the Vietnam War and the Great Society. This led to the beginning of the Great Inflation (1965 to 1982). The Fed also began following Keynesian doctrine (the Phillips Curve tradeoff) and made achieving full employment (at the expense of inflation) its paramount policy goal. As inflation and inflationary pressures mounted in the 1970s, several attempts by the Burn's FOMC to reduce inflation faltered when it led to recession and rising unemployment, leading to a ratcheting up in inflation and inflation expectations (Bordo and Orphanides 2013). Accommodation of two oil price shocks also contributed to the run up in inflation. By the late 1970s the Fed had lost considerable credibility for low inflation. This culminated in a run on the dollar in 1978.

In 1979 President Carter appointed Paul Volcker as Chairman of the Fed with a mandate to end inflation. Volcker followed a monetarist policy strategy, targeting non borrowed reserves and letting interest rates be determined by market forces. Interest rates rose to close to $20 \%$ by 1980 . Volcker's tight money policy triggered a sharp recession in 1979- 80. It was aggravated by the Carter administration imposing controls on credit card expenditures. In reaction the Fed loosened policy in late 1980. Immediately inflation and inflationary expectations rebounded. Several months later, with the support of the newly elected President Reagan, Volcker reapplied the monetary brakes triggering a second recession and this time it did not stop tightening despite the unemployment rate rising well above $10 \%$ until inflation and inflation expectations abated in 1982. The Fed's credibility suffered after the first recession and only was regained after the second (more severe) Fed induced downturn (Bordo,Erceg, Levin and Michaels 2007).

The Fed reestablished its credibility for low inflation by the mid 1980s seen in declines in nominal interest rates, in the TIPs spread and in various measures of inflation expectations. The 20 year episode of good economic performance is referred to as the Great Moderation. Alan Greenspan took over as Fed Chairman in 1987. He quickly prevented a major stock market crash from leading to a banking crisis and then followed the Volcker approach to maintaining credibility for low inflation. This policy was put to the test by the 
inflation scare of 1994 when rising long-term bond yields signaled a run up in inflationary expectations. The Fed tightened sharply, raising real interest rates. And then when inflation expectations eased, the Fed loosened, preventing a recession. (Goodfriend 1993).

The Great Moderation ended with the Financial Crisis of 2007-2008. Loose Federal Reserve policy of keeping the Federal Funds rate well below the Taylor rule rate from 2003 to 2005, in an attempt to head off potential deflation, added fuel to a burgeoning real estate boom which burst in 2006 triggering the crisis. (Taylor 2007, Bordo and Landon Lane 2013 b). The Fed reacted to the crisis by following aggressive monetary policy of cutting the FFR in the fall of 2007, opening the discount window to many nonbank financial institutions and non traditional markets and by a controversial bailout policy in fall 2008 ( bailing out Bear Stearns, AIG and the GSEs ) and letting Lehman fail in October. That action triggered a global financial crisis. The Fed reacted to the panic by cutting the FFR to zero and instituting several unorthodox discount window facilities. These policies combined with the Treasury's TARP plan, stress tests and an inter central bank swap arrangement ended the crisis. By late fall 2008 the Fed's policy rate had hit the zero lower bound and with the recession still on going, the Fed instituted its Quantitative Easing policy (QE1) -- the purchase of long term Treasuries and mortgage backed securities. This unconventional policy was followed in the next 4 years by three other packages in the face of an unprecedented (after a financial crisis) slow recovery (Bordo and Haubrich 2012). These policies have quadrupled the Fed's balance sheet, and many argue could lead to a future inflation policy. The Fed may have lost considerable credibility with the crisis and time will tell if it regains its credibility for low inflation by how it exits from QE.

\section{Canada: Bank of Canada}

The Bank of Canada was created in 1935. Two historic events during the 1930s were influential in the formation of the central bank. The first, of course, was the Great Depression. The second event was the end of the Gold Standard. Unlike the United States to the south Canada saw no bank failures in the 1930s. Neither did the country experience a surge in inflation when the link to gold was suspended. Indeed, part of the impetus for the creation of the Bank of Canada was the fear of deflation (e.g., Burdekin and Siklos 2004). An equally strong motive for the creation of a central bank was a political one. The MacMillan 
Commission, a royal commission struck in 1993 to investigate the possibility of establishing a central bank in Canada, returned a favorable, though narrow, majority report after conducting hearings nationwide. As Bordo and Redish (1987, p. 415) note: "Domestically, in an environment where traditional trust in the beneficial nature of the market system was eroding and a spirit of nationalism was rising, political pressure was mounting to halt the deflation which was frequently blamed on the concentrated banking industry."

Other political forces also contributed to the creation of the Bank of Canada. Canada had no central bank that could be used to manage monetary policy, including the exchange rate. Indeed, paralleling the creation of the Bank of Canada was the introduction of the Exchange Fund Account in 1935 to "aid in the control and protection of the external position of the Canadian monetary unit." (Statutes of Canada 1935) The Bank, which officially began operations in March 1935, was initially a private institution with stocks issued and dividends paid out to shareholders up to a stated maximum. After the 1936 election, however, the Bank was nationalized and, by 1938, the government acquired all of the shares.

Around the time of the outbreak of World War II, Canada introduced exchange controls. Price controls would also shortly thereafter be put in place. These were administered by the Foreign Exchange Control Board, chaired by the Governor of the Bank of Canada. Wage and price controls were also introduced and the war was financed by the issuance of a series of Victory bonds. These long-term loans would create some difficulties for the Bank of Canada during the second half of the 1950s (see below). More controversially, the Governor of the Bank would also preside over the Industrial Development Bank, a vehicle to spur economic growth and employment in the postwar era. The result was to effectively neutralize monetary policy as a stabilization tool to manage inflation (e.g., see Deutsch 1957).

The earliest days of the Bank in the postwar era were marked by the creation of a market for short-term government debt as well as facilitate the development of a money market. This was deemed vital given the contemporary trend toward greater government involvement in the economy. An important feature of Bank of Canada policy in the early years was the resort to moral suasion. The aim was to persuade the commercial banking 
system to follow lending policies that suited the macroeconomic objectives of the central bank. The highly concentrated nature of the Canadian banking system made such a policy practical.

Once World War II ended high levels of government debt, the need to re-intermediate the Canadian financial system following wartime controls, meant that the Bank needed to prepare to intervene in the financial system to ensure a smooth exit from an era of forced 'cheap money'. In addition, the postwar era would usher in the creation of the Bretton Woods system of pegged exchange rates. Canada adopted the system but, in the early 1950s, became the first country to opt out of the exchange rate system. In spite of the heavy criticism it faced, Canada adhered to a form of floating exchange rates until the early 1960s when it returned to the Bretton Woods fold (e.g., see Helleiner 2006). In spite of the flexible exchange rate regime the nominal exchange rate did not vary a great deal throughout most of the decade. Unlike other parts of the world, capital remained mobile.

The decade of the 1950s was an eventful one for at least two other reasons. First, the Bank of Canada arguably became the first central bank to adopt an interest rate instrument to signal the stance of monetary policy (e.g., see Siklos 2010). Next, and perhaps most importantly, the Bank experienced its first institutional crisis whose consequences are still being felt to this day. Following the boom and bust period in the aftermath of the Korean War the Canadian economy once again grew vary rapidly during the mid-1950s and the Bank publicly worried about rising inflation. Through its encouragement of the development of a nascent money market the Bank engineered successive increases in the interest rate even as the Canadian and U.S. economies, the latter by far its largest trading partner, were showing signs of an imminent and sharp slowdown. The Bank also faced the soon to mature Victory bonds from the World War II era and the resulting shift in the maturity structure of the government debt complicate matters as well.

James Coyne, who became the second Bank of Canada Governor in 1955, believed strongly that the bank needed to be interventionist, especially in the control of inflation. His policy of high interest rates at a time of rising unemployment created severe tension with the government of the day led by Prime Minister John Diefenbaker. Publicly, doubts about the correctness of the Bank's monetary policy were also raised to unprecedented levels. As one notable economist of the time opined (Gordon 1961, p. 15) the Bank “...has 
its eye fixed on the moral wickedness of the slightest changes of inflation and is unmoved by the patent facts of growing unemployment and stagnating national income." By 1961 the controversy reached a climax when the government introduced a motion declaring the post of Governor vacant. The elected House of Commons passed the motion but the unelected Senate, where Coyne found support, did not. Coyne, feeling vindicated, resigned. Regardless of who was right or wrong during the crisis the BoC lost much of its credibility during the Coyne years.

The resignation would, however, have lasting consequences on the Bank. Louis Rasminsky, who took over as Governor, did so on the condition that a new Bank of Canada Act contain a directive such that, in the event of a disagreement over policy issues, the government was required to publicly explain its disagreement and the Governor would be directed to implement the policy. Since the so-called Rasminsky directive was included in the Bank of Canada Act, it has never been invoked. Indeed, it has proved to be the device that guarantees the autonomy of the Bank from direct political interference. Indeed, the Rasminsky era succeeded in re-establishing central bank credibility.

The period the 1960s was a time of fixed exchange rates with the Canadian dollar pegged at US 92.5 cents. Relative economic peace came to an end with the two oil price shocks of the 1970s. The resulting stagflation culminated in the Saskatoon Monetary manifesto of then Governor Gerald Bouey, who advocated the adoption of monetary targeting to buttress Bank of Canada credibility. At the time the Governor (Courchene 1976, p. 25) insisted that "Whatever else may need to be done to bring inflation under control, it is absolutely essential to keep the rate of monetary expansion within reasonable limits." Termed the strategy of gradualism the objective of the policy was to bring down the rate of money supply growth from an initial range of $10-15 \%$ per annum. The policy succeeded in part because, as Bouey famously stated, "we didn't abandon the monetary aggregates, the abandoned us". Once again the Bank suffered a loss of credibility when it failed to control inflation.

The failure of monetary targeting, the end of the Bretton Woods era conspired to create a void in monetary policy. There was no monetary anchor. As a result, pressure came from several quarters to stem inflation with new tools. In 1987, during the course of the Hanson Lecture Governor John Crowe argued that "monetary policy should be geared so as to 
achieve a pace of monetary expansion that promotes price stability in the value of money. This means pursuing a policy aimed at achieving and maintaining stable prices." (Crowe 1988, p. 4) Shortly after New Zealand adopted inflation targeting (see below), the Bank, with the tacit encouragement of the federal government, adopted inflation reduction targets in 1991. However, the adoption of a new anchor of policy was not without considerable controversy, somewhat reminiscent of the Coyne affair three decades earlier. The issue was once again whether, in the pursuit of price stability, the Bank deliberately engineered or made worse the recession of the early 1990 s.

Canada's inflation targeting regime began with goals to reduce inflation, first to $3 \%$ by 1992, and then to $2 \%$ by 1995 . Inflation fell more quickly than anyone expected and a target range of between 1 to $3 \%$, with a $2 \%$ mid-point inflation target, was adopted. Since that time the inflation target remit has been renewed every five years and inflation has remained within the target range much of the time since then. The inflation targeting regime has been in place for over two decades and is, arguably, a success story. Along with the adoption of inflation targets was a commitment to a floating exchange rate and the gradual expansion of the transparency of the Bank of Canada. Governor Gordon Thiessen was largely responsible for these and other changes (e.g., see Laidler 1991, and Laidler and Robson 1993).

The inflation targeting regime survived the global financial crisis but the regime has not been left unscathed. While Canada escaped the worst of the GFC, the events of 2008-13 provide some fodder for the critics of the Bank. The recession of 2008-9 was short-lived but among the sharpest of the post-war era (see Cross and Bergevin 2012). Even if the 2\% inflation target has proved to be a durable anchor, observed inflation has been below target roughly half the time since 2005, including all of 2009 and 2013. Prior to 2005 CPI inflation also remained below 2\% between 1998 and early 2001. Conventional central banks actions, via changes in a central bank policy rate, became less effective and appeared inoperative once the zero lower bound was reached. Consequently, much of the advanced world adopted unconventional monetary policies. The shift implies emphasis on policies that impact the balance sheet of the central bank.

Canada remained in the eye of the storm that was creating havoc across the industrialized economies. A sound banking system and little bubble-like activity in the 
housing sector, meant that two direct channels that propagated the financial crisis in the U.S. were absent in Canada. Nevertheless, the Bank of Canada could not avoid the movement of policy rates toward the ZLB. Regardless, the accommodative monetary policy stance still failed to dent the unease about negative spillovers from the deepening U.S. recession; a phenomenon that was apparent throughout the industrial world.

Why, even if it Canada's economy was relatively resilient to the sizeable adverse shocks from abroad, could the Canadian economy not fully avoid a recession and the rapid fall in inflation? These events appeared to contradict the intent of the inflation targeting regime which relies crucially on a floating exchange rate regime believed to act as a shock absorber. Consequently, the Bank once again was thrust at the forefront of monetary policy actions when it unveiled its forward guidance policy in April 2009. The aim was convince the public that the mid-point of the inflation target would not be abandoned and, to underscore its determination to return inflation to its $2 \%$ goal, by stating that the policy rate would remain at its ZLB for up to a year. Nevertheless, worried over the possibility that inflationary expectations might become unanchored, the Bank raised the policy rate prior to the expiry date of the CC policy. By some accounts (e.g., Siklos and Spence 2010) the exit was credible. Of course, the CC strategy was modest, took place under crisis conditions, and had a limited horizon.

While the BoC has been a leader in promoting the virtues of forward guidance, to good effect, the central bank appears occasionally incapable of providing clarity about when the economy might return to a state that calls for a more 'normal' monetary policy stance. For example, in the April 2010 MPR, the BoC first sought to justify why monetary policy might remain loose even after signs of inflation and a return to capacity might otherwise have led markets to believe that the policy rate would rise. Unfortunately, the explanation was predicated on an inflation rate below target at a time when observed inflation was above target.

The Bank of Canada has the legal authority and flexibility to act as a lender of last resort through the provision of emergency liquidity assistance or by conducting outright asset purchases. Like other major central banks, the BoC responded to the crisis by significantly extending its lending facilities and aggressively lowering the policy rate. After hitting the zero lower bound on interest rates and worried that the expansionary macroeconomic 
policies were not sufficient to spark a recovery in the real economy, the BoC used calendarbased conditional commitment to maintain the policy rate at the ZLB. Other major central banks were more hesitant in making such commitments, and acted cautiously when they did.

Despite some temporary failures to control inflation or anticipate deflation risks from time to time inflation expectations remain firmly anchored at the $2 \%$ inflation target. Hence, there is every reason to believe that the inflation targeting regime has been a credible one.

\section{New Zealand: The Reserve Bank of New Zealand}

Like the Bank of Canada the Reserve Bank of New Zealand (RBNZ) was established in 1934 following the Great Depression. The RBNZ was not created to promote monetary stability. Rather, unlike many other central banks, it was created to establish separate monetary and banking systems between New Zealand and Australia (Hawke 1972). Since commodity prices had considerable impact on the New Zealand economy it was believed that a central bank, as was the case elsewhere, could be a vehicle to soften the blows of large shifts in commodity prices. Of course, a vehicle to insulate the New Zealand economy from foreign shocks was dependent on the type of exchange rate regime. Although the New Zealand dollar's was pegged to the pound sterling the government hoped that the creation of a central bank would signal a form of independence from Australia in the financial and economic realms e.g., see RBNZ 2007).

Paralleling the Canadian experience the RBNZ was two-thirds owned by private shareholders but nationalization took place in 1936 when a labour government came into power. New legislation would soon indicate that the government intended to use the RBNZ as a tool to finance expansion of the public sector. There was no pretense of independence from the Minister of Finance. During the first two decades or so of its existence the lack of independence did not appear to matter much as the New Zealand economy grew rapidly and unemployment remained low. Nevertheless, economic imbalances were building and these are reflected in rising inflation rates and pressure on the exchange rate (e.g., see RBNZ 2009). Therefore, there is little reason to believe that the RBNZ had much credibility as it was unable to act autonomously. 
The RBNZ went through World War II under an increasingly interventionist government. Surging demand for its commodities to support the war effort, combined with capital controls that would remain in place until the mid 1980s, as well as import restrictions, meant that the government took near total control of the economy. The RBNZ became a vehicle to help finance the war effort but the positive externalities of the war on New Zealand's economy also permitted the war debts to be repaid quickly following the end of hostilities. The public was willing to put up with the necessary austerity measures to assist with the effort at debt repayment. Price controls were also adopted.

When the rest of the world began to relax restrictions on the movement of capital and reduce import tariffs during the 1950s, New Zealand took a different route. It sought to protect its commodity exports, vital to national economic growth, but increasingly restricted imports and other forms of direct economic controls on its citizens. Unfortunately for New Zealand when the UK joined the European Economic Community in 1973, combined with the dying days of the Bretton Woods system, conspired to create an economic shock (e.g., See Singleton et.al. 2006) that would eventually lead to major economic and financial reforms.

From the oil price shocks of the 1970s through to the loss of large export markets New Zealand's economy began to experience stagflation on a major scale. When the continued attempt to deal with the underlying pressures on New Zealand's economy by resorting to more direct controls, including wage and price controls, could no longer be sustained an economic crisis erupted. Poor economic conditions were exacerbated by the autocratic style of then Prime Minister Muldoon who was determined to avoid rising unemployment. In the event, inflation soared from below $5 \%$ in the early 1970 s to almost $20 \%$ by the early 1980s. There were also other forces that would contribute to creating unsustainable tensions in the economy. Monetary policy was, during the 1970s, governed by a reserve requirement scheme. In the meantime interest rates were gradually being liberalized while the end of the Bretton Woods era brought a period where the New Zealand dollar was pegged to a changing basket of currencies. This did not prevent several large devaluations of the dollar followed by the adoption of a 'crawling peg' regime by the end of the decade of the 1970s. A currency crisis erupted in 1984 and, together with an election that year, 
brought in a new government. Once again it is difficult to speak of any RBNZ credibility as its ability to conduct monetary policy was severely constrained.

In the years following the elections of 1984 landmark reforms were introduced that affected all aspects of New Zealand's economy. Perhaps the most significant reforms were in the area of monetary policy. The RBNZ would eventually be made autonomous from government and accountable for meeting an inflation target. May of the reforms were introduced by the newly installed Finance Minister at the time, Roger Douglas. As part of the program of reform the New Zealand dollar would float. The determination to maintain the float is evident from the fact that the RBNZ did not intervene in foreign exchange markets until 2007.

The changes in monetary policy were enshrined in the RBNZ Act of 1989. The focus of monetary policy was the maintenance of price stability to be defined by an inflation target. Henceforth, there would be a clear indicator by which the public and markets could assess the credibility of the RBNZ. The target would be regularly revisited thanks to a Policy Targets Agreement (PTA) which would have to be signed following each election as a signal of the commitment of both the central bank and the government to maintain price stability. Although initially the inflation target range included $0 \%$ subsequent assessments of the conduct of monetary policy, together with the adoption of inflation targets elsewhere which explicitly excluded the $0 \%$ value eventually produced a $1-3 \%$ target range that survives to this day. Provisions were made in the legislation to bring the Governor to account in case the targets were breached. This happened on at least two occasions but, in both cases, the Governor was not removed and inflation eventually returned to target although the RBNZ's credibility was dented. Some of the difficulties lay in the manner in which inflation is measured. For example, a rise in interest rates would filter through mortgage rates and rents and these were incorporated into the CPI. Clearly, the appropriate response was not to further raise interest rates unless inflation expectations became unanchored. In large part for this reason the role of central bank communication became central to RBNZ policy and the central bank became among the most transparent in the world (e.g., see Siklos 2002, Dincer and Eichengreen 2007).

Two other events in the RBNZ's history are noteworthy. Realizing that interest rate changes and exchange rate changes are interrelated in a floating rate regime the RBNZ 
publicized and, later, adopted a monetary conditions index (MCI) as a primary signal in communicating the stance of monetary policy. Interestingly, the $\mathrm{MCI}$ has Canadian roots although the BoC never adopted the $\mathrm{MCI}$ as an intermediate instrument of policy. When markets became too focused on changes in the MCI this complicated the task of communicating the policy intentions of the RBNZ and it was forced to abandon its usage (e.g., see Siklos 2000). Second, in the aftermath of the Asian financial crisis of 1997-98 followed by the Fed's reaction to the bursting of the tech bubble in 2001 and the slow tightening of monetary policy in the US during the early 2000s, the RBNZ began to reconsider its ban on foreign exchange intervention. After some public consultations and an international conference on the monetary and fiscal policy regime in mid-2007 RBNZ 2006), the RBNZ adopted foreign exchange intervention guidelines. In the event the RBNZ only intervened a few times since the policy was adopted and the commitment to inflation targeting and, for the floating exchange rate regime remains undiminished to this day. There is no imminent sign that the inflation targeting regime will be reconsidered. It remains a credible nominal anchor for monetary policy. 


\section{Narratives' References}

Allan Melktzer (2003) A History of the Federal Reserve Volume 1. University of Chicago Press.

Andreas Beyer,Vitor Gaspar, Christina Gerberding and Otmar Issing, ( 2013), " Opting Out of the Great Inflation: German Monetary Policy after the Breakdown of Bretton Woods; in Michael D. Bordo and Athanasios Orphanides (eds) The Great Inflation; The Rebirth of Modern Central Banking. University of Chicago Press for the NBER

Barry Eichengreen (1992) Golden Fetters. Oxford University Press

Bell, S. (2004), Australia's Money Mandarins (Cambridge: Cambridge University Press).

Burdekin, R., and P.L. Siklos (2004), "Fears of Deflation and the Role of Monetary Policy: Some Lessons and An Overview", in R.C.K. Burdekin and P.L. Siklos (Eds), Deflation (Cambridge: Cambridge University Press), pp. 1-30.

Carl Berg and Lars Jonung (1999) "Pioneering Price Level targeting: The Swedish Experience 193-1937" Journal of Monetary Economics 43(3) :525-551

Courchene, T. (1976), Money, Inflation and the Bank of Canada: An Analysis of Canadian Monetary Policy from 1970 to Early 1975 (Toronto: C.D. Howe Institute).

Cross, P., and P. Bergevin (2012), "Turning Points: Business Cycles in Canada since 1926", C.D. Howe Commentary No. 366, October.

Crow, J. (1988), “The Work of Canadian Monetary Policy”, Eric Hanson Memorial Lecture, January, University of Alberta.

Deutsch, J. (1957), "The Canadian Treasury and Monetary Policy", American Economic Review 47 (May): 220-228.

Dincer, N.N., and B. Eichengreen (2007), "Central Bank Transparency: Where, Why, and With What Effects?" NBER working paper 13003, March.

Eric Monnet (2013) "Monetary Policy without Interest Rates. Evidence from France's Golden age (1948-1973) Using a Narrative Approach" Banque de France (mimeo)

Erling Steigum (2009) “The Boom and Bust Cycle in Norway' in Lars Jonung et al (2009) The Great Financial Crisis in Finland and Sweden. Edward Elgar Publishers Nortthampton, Mass pp 202-244

Eugene White (2007) "The Crash of 1882, Counterparty Risk, and the Bailout of the Paris Bourse" NBER Working paper 12933

Forrest Capie (2010) The Bank of England 1950s to 1979. Cambridge University Press Barry Eichegreen. (1992) Golden Fetters. Oxford University Press. 
Franco Giavazzi and Michele Pagano (1991) "The Advantage of Tying One's Hands:EMS Discipline and Central bank Credibility" European Economic Review Vol 38, pp 303-330.

Georg Rich (1997) "Monetary Targets as a Policy Rule: Lessons from the Swiss Experience" Journal of Monetary Economics 39(1) pp 113-141

Gollan, R. (1968) The Commonwealth Bank of Australia: Origins and Early History (Canberra: ANU Press).

Gordon, H.Scott (1961a) The Economists Versus the Bank of Canada (Toronto: The Ryerson Press).

Grenville, S. (1996), "Recent Development in Monetary Policy: Australia and Abroad", Australian Economic Review (1st Quarter): 29-39.

Guiseppe Tattara (2000) "Paper Money but a Gold Debt: Italy on the Gold Standard' Explorations in Economic History, vol 40 pp 122-142

H.C. Johnson (1997) Gold, France and the Great Depression, 1919-1932. Yale University Press

Hawke, G. (1973), Between Governments and Banks (Wellington: Reserve Bank of New Zealand

Helleiner, E. (2006), Towards North American Monetary Union? A Political History of Canada's Exchange Rate Regime (Montreal: McGill-Queen's University Press).

Jan Qvigstad (2013) "On Institutions-Fundamentals of Confidence and Trust" Norgesbank (mimeo)

John B. Taylor (2007) "Housing and Monetary Policy " in Housing Finance and Monetary Policy. Federal Reserve Bank of Kansas City

John Singleton (2011) Central Banking in the Twentieth Century. Cambridge University Press

Klas Fregert and Lars Jonung (2008) "Inflation Targeting is a Success So Far: 100 Years of Evidence from Swedish Contracts" Economics Open Access E Journal Vol 2 2008-31

Laidler, D.E.W. (1991), "How Shall We Govern the Governor?: A Critique of the Governance of the Bank of Canada", The Canada Round 1 (Toronto: C.D. Howe Institute).

Laidler, D.E.W., and W.P. Robson (1993) The Great Canadian Disinflation: The Economics and Politics of Canadian Monetary Policy in Canada, 1988-93 (Toronto: C.D. Howe Institute).

Lars Jonung (1984) “Swedish Experience Under the Classical Gold Standard:1873-1914” in 
Leland Yeager (1976) International Monetary Relations; Theory, History and Policy. Second Edition. Harper and row.

Liaquat Ahamed (2010) The Lords of Finance. Penquin Books

Marvin Goodfriend (1993) "Interest Rate Policy and the Inflation Scare Problem 19791992" Federal Reserve Bank of Richmond Quarterly Vol 79/1 Winter

Michael Bordo (1981) "The Classical Gold Standard: Some Lessons for Today" Federal Reserve Bank of St. Louis Review, Vol 63, No.6 May.

Michael Bordo (1990) 'The Lender of Last Resort: Alternative Views and Historical Experience' Federal Reserve Bank of Richmond Economic Review March

Michael Bordo (1993) The Bretton Woods International Monetary System: An Historical Overview" in Michael D. Bordo and Barry Eichengreen (eds) A Retrospective on the Bretton Woods System. University of Chicago Press for the NBER.

Michael Bordo and Pierre L. Siklos (2014), "Central Bank Credibility, Reputation and Inflation Targeting in Historical Perspective", NBER working paper 20693, November.

Michael Bordo and Anna J Schwartz (1996) "The Operation of the Specie Standard: Evidence for Core and Peripheral Countries, 1880-1990" in Barry Eichengreen and Jorge Braga de Macedo ( eds) Historical Perspectives on the Gold Standard; Portugal and the World. Routledge Publishers

Michael Bordo and Athanasios Orphanides (2013) The Great Inflation; The Rebirth of Modern Central Banking. University of Chicago Press for the NBER

Michael Bordo and Bernhard Eschweiler (1994), "Rules, Discretion and Central Bank Independence: The German Experience 1880-1989" in Pierre Sikos (ed) Varieties of Monetary Reform: Lessons and Experience on the Road to Monetary Union. Boston, Kluwer Academic Publishers

Michael Bordo and David Wheelock (2013) "The Promise and Performance of the Federal Reserve as Lender of Last Resort 1914-1933' in Michael D. Bordo and Will Roberds A Return to Jekyll Island. Cambridge University Press

Michael Bordo and Finn Kydland (1995) "The Gold Standard as a Rule: An Essay in Exploration" Explorations in Economic History. October

Michael Bordo and Harold James (2007) "From 1907 to 1946: A Happy Childhood or a Troubled Adolescence? in SNB. The Swiss National Bank 1907-2007. Neue Zurcher Zeitung

Michael Bordo and Hugh Rockoff (1996) "The Gold Standard as a Good Housekeeping Seal of Approval" Journal of Economic History June 
Michael Bordo and John Landon Lane (2013a) "Does Expansionary Monetary Policy Cause Asset Price Booms: Some Historical and Empirical Evidence” NBER Working Paper 19585 October

Michael Bordo and John Landon Lane (2013b) “What Explains House Price Booms?: History and Empirical Evidence" NBER Working paper 19584 October

Michael Bordo and Joseph Haubrich (2012) "Deep Recessions, Fast Recoveries and Financial Crises: Evidence from the American Record" NBER Working Paper 18194 une

Michael Bordo and Pierre Cyrille Hautcoeur (2007) "Why Didnt France Follow the British Stabilization after World War I? European Review of Economic History, Vol 11, No.1. April, pp 3-37

Michael Bordo and Ronald MacDonald (2002) "The Interwar Gold Exchabge Standard: Credibility and Monetary Independence" Journal of International Money and Finance.

Michael Bordo and Ronald MacDonald (2005) "Interest Rate Interactions in the Classical Gold Standard: 1880-1914; Was There Monetary Independence?" Journal of Monetary Economics. March

Michael Bordo, Chris Erceg, Andrew Levin and Ryan Michaels (2007) "Three Great American Disinflations" NBER Working Paper No. 12982 March

Michael Bordo, Dominique Simard and Eugene White (1995) "France and the Bretton Woods International System" in Jaime Reis (ed) The History of International Monetary Arrangements. MacMillan. London

Michael Bordo, Owen Humpage and Anna Schwartz (2014) Strained Relations: U.S. Monetary Policy and Foreign Exchange Operations in the Twentieth Century. University of Chicago Press (in press)

Michael Bordo, Thomas Helbling and Harold James (2007) "Swiss Exchange Rate Policy in the 1930s. Was the Delay in Devaluation Too High a Price to Pay for Conservatism?" Open Economies Review

Michael D Bordo and Angela Redish (1987), "Why Did the Bank of Canada Emerge in 1935?", Journal of Economic History 47 (June): 405-17.

Michael D Bordo and Anna J Schwartz (eds) (1984) A Retrospective on the Classical Gold Standard 1821 -1931. University of Chicago Press for the NBER pp $361-404$

Michele Fratianni and Franco Spinelli (1997) A Monetary History of Italy. Cambridge University Press

Milton Friedman and Anna Schwartz (1963) A Monetary History of the United States 1867 to 1960 . Princeton University Press 
New Zealand Treasury and Reserve Bank of New Zealand (2006), Testing Stabilization Policy Limits in a Small Open Economy: Proceedings from a Macroeconomic Policy Forum (Wellington: NZ Treasury).

Oyvind Eitrheim and Lars Oksendal (2013) "The Cost of the Post War Economic Order in Norway: Reflections in Hindsight" Norges bank (mimeo)

Oyvind Eitrheim, Jan F. Quigstad and Oystein Bieltvedt Skeie (2006) "Price Stability has Been the Historical Norm. What Distinguishes the Abnormal? Norgesbank (mimeo).Geraats. P. (2014), "Monetary Policy Transparency", in J. Foessbaeck and L. Oxelheim (Eds), Oxford Handbook of Institutional and Economic Transparency (Oxford: Oxford University Press), pp. 68-97.

Pierre Cyrille Hautcoeur, Angelo Riva and Eugene White (2014) "Can Moral Hazard Be Avoided? The Banque De France and the Crisis of 1889" Journal of Monetary Economics (forthcoming)

Reserve Bank of Australia (1987), Annual Report (Sydney: Reserve Bank of New Zealand).

Reserve Bank of New Zealand (2007), The Reserve Bank and New Zealand's Economic History (wellington: Reserve Bank of New Zealand).

Riccardo DiCecio and Edward Nelson (2013) “ The Great Inflation in the United States and the United Kingdom: Reconciling Policy Decisions and Data Outcomes' in Michael Bordo and Athanasios Orphanides (eds) ( 2013) The Great Inflation: The Rebirth of Modern Central Banking. University of Chicago Press for the NBER

Siklos, P.L. (2002), The Changing Face of Central Banking (Cambridge: Cambridge University Press).

Siklos, P.L. (2010) "Revisiting the Coyne Affair: A Singular Event that Changed the Course of Canadian Monetary History", Canadian Journal of Economics 43 (August): 994-1015.

Siklos, P.L. (2000) "Is the MCI a Useful Signal of Monetary Policy Conditions? An Empirical Investigation", International Finance 3 (November): 413-38.

Siklos, P.L., and A. Spence (2010), "Face-Off: Should the Bank of Canada Relase Its Projections for the Interest Rate Path?", C.D. Howe Backgrounder 134, October, available from http://www.cdhowe.org/pdf/Backgrounder_134.pdf.

Siklos, P.L., and O. Karagedikli (2013), "A Bridge Too Far? RBNZ Communication, The Forward Interest Rate Track, and the Exchange Rate" (with Özer Karagedikli) in Central Bank Transparency, Decision-Making, and Governance: The Issues, Challenges, and Case Studies (Cambridge, Mass.: MIT Press - 2013), pp. 273-310.

Singleton, J., with A. Grimes, G. Hawke and F. Holmes (2006), Innovation and Independence: The Reserve Bank of New Zealand (Wellington: Auckland University Press). 
SNB (2007) The Swiss National Bank 1907-2007. Neue Zurcher Zeitung Publishing

Statutes of Canada (2014), laws.justice.gc.ca/eng/.

Stevens, G. (2003), "Inflation Targeting: A Decade of Australian Experience", Reserve Bank of Australia Bulletin, April: 17-27.

Swan, T.W. (1940), "Australian War Finance and Banking Policy", Economic Record 16 (June): 50-67.

Walter Bagehot (1873) Lombard Street. London 